\title{
Seasonal characteristics of tropical marine boundary layer air measured at the Cape Verde Atmospheric Observatory
}

L.J. Carpenter ${ }^{1}$, Z.L. Fleming ${ }^{2,3}$ K.A. Read ${ }^{1,4}$, J.D. Lee ${ }^{1,4}$, S.J. Moller ${ }^{1}$, J. Hopkins ${ }^{1,4}$, R. Purvis ${ }^{1,4}$, A.C. Lewis ${ }^{1,4}$, K. Müller $^{5}$, B. Heinold ${ }^{5}$, H. Herrmann ${ }^{5}$, K. Wadinga Fomba ${ }^{5}$, D. van Pinxteren ${ }^{5}$, C. Müller ${ }^{5}$, I. Tegen ${ }^{5}$, A. Wiedensohler ${ }^{5}$, T. Müller ${ }^{5}$, N. Niedermeier ${ }^{5}$, E.P. Achterberg ${ }^{6}$, M.D. Patey ${ }^{6}$, E.A. Kozlova ${ }^{7 *}$, M. Heimann ${ }^{7}$, D.E. Heard ${ }^{8}$, J.M.C. Plane ${ }^{8}$, A.S. Mahajan ${ }^{8^{* *}}$, H. Oetjen ${ }^{8^{* * *}}$, S. Vaughan ${ }^{8}$, T. Ingham ${ }^{8,9}$, D. Stone ${ }^{8,10}$, L. Whalley ${ }^{8,9}$, M. Evans ${ }^{10}$, M.J. Pilling ${ }^{8}$, R.J. Leigh $^{11}$, P.S. Monks ${ }^{3}$, A. Karunaharan ${ }^{3}$, J. Tschritter ${ }^{12}$, D. Pöhler ${ }^{12}$, U. Frie ${ }^{12}$, R. Holla ${ }^{12}$, L. Mendes ${ }^{13}$, H. Lopez ${ }^{13}$, B. Faria $^{13}$, A.J. Manning ${ }^{14}$, D.W.R. Wallace ${ }^{15}$

${ }^{1}$ Department of Chemistry, University of York, York, YO10 5DD, UK

${ }^{2}$ National Centre for Atmospheric Science, Department of Chemistry, University of Leicester, Leicester, LE1 7RH, UK

${ }^{3}$ Department of Chemistry, University of Leicester, Leicester, LE1 7RH, UK

${ }^{4}$ National Centre for Atmospheric Science, University of York, York, YO10 5DD, UK

${ }^{5}$ Leibniz-Institut für Troposphärenforschung e.V., Permoserstr. 15, 04318 Leipzig, Germany

${ }^{6}$ School of Ocean and Earth Science, National Oceanography Centre Southampton, University of Southampton, Southampton SO14 3ZH, UK

${ }^{7}$ Max-Planck-Institut für Biogeochemie, Jena, Germany

${ }^{8}$ School of Chemistry, University of Leeds, Leeds, LS2 9JT, UK

${ }^{9}$ National Centre for Atmospheric Science, School of Chemistry, University of Leeds, Leeds, LS2 9JT, UK

${ }^{10}$ Institute for Climate \& Atmospheric Science, School of Earth \& Environment, University of Leeds, LS2 9JT, UK

${ }^{11}$ Earth Observation Science, Department of Physics \& Astronomy, University of Leicester, UK

${ }^{12}$ Institute of Environmental Physics, University of Heidelberg, Heidelberg, Germany

${ }^{13}$ Instituto Nacional de Meteorologia e Geofísica (INMG), Mindelo, Sao Vicente, Cape Verde

${ }^{14}$ The Met office, Exeter, Devon EX1 3PB, UK

${ }^{15}$ Leibniz-Institut für Meereswissenschaften (IFM-GEOMAR) Marine Biogeochemie, Düsternbrooker Weg 20, 24105 Kiel, Germany

*Now at School of Environmental Sciences, University of East Anglia (UEA), Norwich, UK

**Now at Laboratorio de Ciencias de la Atmósfera y el Clima (CIAC), Toledo, Spain

***Now at Department of Chemistry, University of Colorado, Boulder, CO 80309, USA

Email contact: lucy.carpenter@york.ac.uk 


\section{Abstract}

Observations of the tropical atmosphere are fundamental to the understanding of global changes in air quality, atmospheric oxidation capacity and climate, yet the tropics are under-populated with long-term measurements. The first three years (October 2006 - September 2009) of meteorological, trace gas and particulate data from the global WMO/Global Atmospheric Watch (GAW) Cape Verde Atmospheric Observatory Humberto Duarte Fonseca (CVAO; $16^{\circ} 51^{\prime} \mathrm{N}, 24^{\circ} 52^{\prime} \mathrm{W}$ ) are presented, along with a characterisation of the origin and pathways of air masses arriving at the station using the NAME dispersion model and simulations of dust deposition using the COSMO-MUSCAT dust model. The observations show a strong influence from Saharan dust in winter with a maximum in super-micron aerosol and particulate iron and aluminium. The dust model results match the magnitude and daily variations of dust events, but in the region of the CVAO underestimate the measured aerosol optical thickness (AOT) because of contributions from other aerosol. The NAME model also captured the dust events, giving confidence in its ability to correctly identify air mass origins and pathways in this region. Dissolution experiments on collected dust samples showed a strong correlation between soluble $\mathrm{Fe}$ and $\mathrm{Al}$ and measured solubilities were lower at high atmospheric dust concentrations. Fine mode aerosol at the CVAO contains a significant fraction of non-sea salt components including dicarboxylic acids, methanesulfonic acid and aliphatic amines, all believed to be of oceanic origin. A marine influence is also apparent in the year-round presence of iodine and bromine monoxide ( $\mathrm{IO}$ and $\mathrm{BrO}$ ), with $\mathrm{IO}$ suggested to be confined mainly to the surface few hundred metres but $\mathrm{BrO}$ well mixed in the boundary layer. Enhanced $\mathrm{CO}_{2}$ and $\mathrm{CH}_{4}$ and depleted oxygen concentrations are markers for air-sea exchange over the nearby northwest African coastal upwelling area. Long-range transport results in generally higher levels of $\mathrm{O}_{3}$ and anthropogenic non-methane hydrocarbons (NMHC) in air originating from North America. Ozone/CO ratios were highest (up to 0.42) in European air masses that contain relatively less well-aged air. In air heavily influenced by Saharan dust the $\mathrm{O}_{3} / \mathrm{CO}$ ratio was as low as 0.13 , possibly indicating $\mathrm{O}_{3}$ uptake to dust. Nitrogen oxides $\left(\mathrm{NO}_{\mathrm{x}}\right.$ and $\mathrm{NO}_{\mathrm{y}}$ ) show generally higher concentrations in winter when air mass origins are predominantly from Africa. High photochemical activity at the site is shown by maximum spring/summer concentrations of $\mathrm{OH}$ and $\mathrm{HO}_{2}$ of $9 \times 10^{6}$ molecule $\mathrm{cm}^{-3}$ and $6 \times 10^{8}$ molecule $\mathrm{cm}^{-3}$, respectively. After the primary photolysis source, the chemistry of $\mathrm{IO}$ and $\mathrm{BrO}$, the abundance of $\mathrm{HCHO}$, and aerosol uptake are important for the $\mathrm{HO}_{\mathrm{x}}$ budget in this region. 


\section{Introduction}

It is well recognised that the tropics are of central importance for many aspects of the chemistry-climate system. High photochemical activity in tropical regions may acutely influence the lifetimes of certain greenhouse gases due to the intense oxidation chemistry occurring in this region. These regions profoundly influence the lifetime and concentrations of gases such as methane (Bloss et al., 2005; Lawrence et al., 2001) and ozone (Horowitz et al., 2003). The injection of tropospheric air into the stratosphere occurs predominantly within the tropics, and species which perturb the stratospheric ozone chemistry must first be processed through the tropics (Bridgeman et al., 2000). Ocean productivity in this region is also particularly sensitive to climate change: a prolonged decrease in net primary productivity of the low-latitude oceans over the last decade is linked to changes in upper-ocean temperature and stratification, which influences the availability of nutrients for phytoplankton growth (Behrenfeld et al., 2006; Richardson and Schoeman 2004).

Despite the crucial role played by the tropical atmosphere, it is under-populated with long-term observations compared to middle and high-latitudes. This paper describes the key scientific and technical features of the recently established Cape Verde Atmospheric Observatory Humberto Duarte Fonseca (CVAO) in the tropical eastern North Atlantic Ocean, including the site location, the instrumentation, and the chemical climatology and major signatures of the data collected so far.

Atmospheric processes in the eastern tropical North Atlantic are significantly influenced by long range transport and atmosphere-ocean exchange of trace chemicals. Cape Verde is located in a region of the Atlantic subject to sporadic but significant dust deposition originating in the African Sahara and Sahel regions. This dust transport has immediate impacts on humans, plus widespread influence on the radiative balance and on marine biological production and biogeochemical cycles. Mills et al., (2004) and references therein showed that community primary productivity in the tropical North Atlantic was nitrogen-limited, that nitrogen fixation was co-limited by iron and phosphorus and this could be stimulated by Saharan dust additions. Recently, Moore et al., (2009) showed that the iron supplied to the region by the large dust inputs controls the nitrogen fixation, which is globally significant. In addition, dust impacts on the ocean heat budget via the scattering of sunlight and reduction in surface solar insolation. As well as affecting the accuracy of some satellite temperature retrievals, dust outbreaks can lead to spatial gradients and significant variability in sea surface temperatures (Martínez Avellaneda et al., 2010). Indeed, aerosols exert their strongest influence on ocean temperatures in this region; $35 \%$ of the observed changes in tropical North Atlantic Ocean summer surface temperatures has been attributed to trends in dust optical depth over the last 3 decades (Evan et al., 2009; Foltz and McPhaden 2008). In turn, the sensitivity of the dust/iron input to desertification and hydrological conditions in Africa (Prospero and Lamb 2003; Sokolik and Toon 1996) and atmospheric transport patterns (Moulin et al., 1997) suggests potential feedbacks between climate-forced changes in oceanic productivity, land-use and climate change.

The CVAO is downwind of the Mauritanian coastal upwelling region off northwest Africa, an area of high marine biological productivity. Observations made in Cape Verde therefore provide rare information on links between climate, marine biology and atmospheric composition changes. The productive marine biology in the region of Cape Verde may be at least partly responsible for the high levels of halogen oxides observed at the CVAO (Mahajan et al., 2010; Read et 
al., 2008). These measurements have provided important observational evidence of the widespread impacts of halogen chemistry in the marine boundary layer, which had remained elusive until now. They show at least a regional effect of halogens on tropospheric ozone caused by the presence of pptv levels of $\mathrm{IO}$ and $\mathrm{BrO}$, with halogens responsible for around $50 \%$ of the daily photochemical $\mathrm{O}_{3}$ loss. Thus, these potentially major climate-related feedbacks involving (a) changes in cover and deposition of continental dust affecting marine ecosystems and the radiative balance and (b) alterations of ocean circulation, upwelling and marine biological production and consequent changes in oceanic gas emissions, can be studied very effectively in the vicinity of Cape Verde.

Here we characterise the air masses arriving at Cape Verde according to their origin and trajectories using the UK Meteorological Office NAME dispersion model (Ryall et al., 2001). We evaluate how these different air masses influence the chemical properties of air in this region, describe the seasonality of gas phase and aerosol composition and the intense photochemical cycling at Cape Verde, and evaluate the performance of a dust model for capturing the wintertime dust events in the region.

\section{Site and sampling descriptions}

\subsection{Site Description}

The CVAO is located on a north-east facing beach at Calhau on the island of São Vicente (16 $51^{\prime} 49 \mathrm{~N}, 24^{\circ} 52^{\prime} 02 \mathrm{~W}$ ), $50 \mathrm{~m}$ from the coastline and $10 \mathrm{~m}$ above sea level, with the north-easterly prevailing trade winds blowing directly off the ocean (Figure 1). The Cape Verde archipelago is volcanic in origin and the islands shelve steeply to the deep abyssal plain beyond the African continental shelf. There are no obvious major coastal features such as extensive shallows or large seaweed beds. Such a site offers a rare opportunity for ground-based studies of clean marine air.

The origins of air drawn in to the trade winds arriving at Cape Verde are diverse; from North America, the Atlantic, Arctic, European and African regions. During late spring and summer, the site mostly receives North Atlantic marine air along the NNE trade winds with an African coastal influence, allowing the long-term study of "background" Atlantic air frequently influenced by the Mauritanian upwelling and its associated oceanic gases. During autumn and winter, Cape Verde is situated in the direct transport pathway of westerly dust from Africa to the North Atlantic. Section 3.1 discusses the air mass histories and trajectories in detail.

\subsection{Infrastructure}

Containerised laboratories form the main infrastructure of the CVAO, one each to house the trace gas measurements, greenhouse gas measurements and aerosol measurements. The site is powered by mains electricity and, from 2009, a wind turbine which provides a peak power of $12 \mathrm{~kW}$. Two back-up generators, wired in series, are triggered automatically at times of complete power-outs and during voltage drops. The generators are housed within a permanent shelter to protect them from the corrosive environmental conditions. There is also a concrete hut to house the main electrical boards and breakers for the site, and a toilet which is supplied by a water tank and feeds a cesspit. There is no running water at the site. Due to the remote nature of the site internet connectivity is possible only through the use of either satellites (currently using the T11N satellite) or long distance $10 \mathrm{~km}$ relayed WiFi link to the Instituto Nacional de Meteorologia e Geofísica (INMG) office in Mindelo. A $30 \mathrm{~m}$ tower is used for the greenhouse gas inlet and for the 
mounting of equipment such as Hi-vol samplers, aerosol filtration instruments, radiometers and meteorological masts. Trace gas measurements of $\mathrm{O}_{3}, \mathrm{CO}$, nitrogen oxides $\left(\mathrm{NO}_{\mathrm{x}}\right.$ and $\mathrm{NO}_{\mathrm{y}}$ ), volatile organic compounds (VOCs), halocarbons, and additional meteorology measurements, are made from the top of the $10 \mathrm{~m}$ tower. A second $\mathrm{O}_{3}$ measurement is concurrently made from a height of $4 \mathrm{~m}$, with the instruments showing no statistically significant difference. A local site manager and technician perform day-to-day maintenance and trouble shooting, and instrument scientists make regular visits to the site.

\subsection{Instrumentation}

The CVAO is within a very small class of WMO-GAW long-term observing stations that measure a comprehensive range of atmospheric parameters. These include meteorological parameters, greenhouse gases, short-lived reactive gas species and aerosols. Table 1 gives details of the instrumentation and their performance, and the data coverage for each measurement. Most measurements at the ground-based observatory began in October 2006, with others phased in after that date. Details are also given of measurements made during the "Reactive Halogens in the Marine Boundary Layer" (RHaMBLe; 18th May-15th June 2007, (Lee et al., 2010)) and the Seasonal Oxidant Study (SOS; 3 separate intensives in 2009) intensive field campaigns.

\subsection{Meteorology}

Temperature, relative humidity, and wind measurements were collected from $30 \mathrm{~m}$ and from $10 \mathrm{~m} \mathrm{at} 1 \mathrm{~Hz}$ then averaged over one minute and ten minutes. Atmospheric pressure and broadband UV radiation were recorded at $4 \mathrm{~m}$. Cloud base height was estimated from a continuous laser ceilometer (Vaisala, CL31) data, and boundary layer height from radiosonde profiles deployed from the island of $\mathrm{Sal}$ (http://esrl.noaa.gov/raobs/). $J\left(\mathrm{O}^{1} \mathrm{D}\right)$ was measured at $4 \mathrm{~m}$ with a $2 \pi$ filter radiometer (Meteorology Consult Gmbh) with $<5 \%$ precision and $~ 20 \%$ accuracy for solar zenith angles (SZA) below $60^{\circ}$, and corrections were applied for the vertical overhead $\mathrm{O}_{3}$ column and changes in sensitivity due to changing SZA.

\subsection{Reactive trace gases}

Ozone is measured every minute from a height of $4 \mathrm{~m}$ and $10 \mathrm{~m}$ using UV absorption instruments (Models 49C and 49i Thermo Scientific). The instruments give an absolute measurement of ozone with a precision of $0.07 \mathrm{ppbv}$ for hourly averaged data. CO mixing ratios from $10 \mathrm{~m}$ are determined using an Aerolaser 5001 fast response VUV analyser, with a detection limit of $<0.5 \mathrm{ppbv}$ on 1 minute average. Measurements of $\mathrm{NO}_{\mathrm{x}}$ are made from $5 \mathrm{~m}$ using a single channel, chemiluminescence $\mathrm{NO}$ detector with a photolytic $\mathrm{NO}_{2}$ converter (Lee et al., 2009). The instrument (Air Quality Design Inc) alternates between measuring $\mathrm{NO}, \mathrm{NO}_{2}$, total $\mathrm{NO}_{\mathrm{y}}$, PANS and Alkyl nitrates in a 10 minute duty cycle, with hourly averaged data giving detection limits of 1.5 pptv and 4 pptv for $\mathrm{NO}$ and $\mathrm{NO}_{2}$, respectively. Total $\mathrm{NO}_{\mathrm{y}}$ is measured with a molybdenum catalytic converter to NO, followed by chemiluminescence detection. PANs and Alkyl nitrates are measured by thermal decomposition to $\mathrm{NO}_{2}$ on a quartz surface at $150{ }^{\circ} \mathrm{C}$ and $350{ }^{\circ} \mathrm{C}$, respectively (Farmer et al., 2006). The $\mathrm{NO}_{2}$ is then photolytically converted to $\mathrm{NO}$ with subsequent chemiluminescence detection.

Hourly VOC and OVOC measurements $\left(\mathrm{C}_{2}-\mathrm{C}_{8} \mathrm{NMHC}\right.$, dimethyl sulphide and $\mathrm{C}_{1}-\mathrm{C}_{3}$ OVOC) are made from $10 \mathrm{~m}$ using a dual-channel gas chromatograph with flame ionisation detection (GC-FID) (Hopkins et al., 2003; Read et al., 
2009). Detection limits for VOCs ranged between 2-10 pptv. Weekly $\mathrm{CH}_{4}$ measurements were obtained using flask samples with subsequent gas chromatographic analysis.

Peroxy radical $\left(\mathrm{HO}_{2}+\mathrm{RO}_{2}\right)$ measurements made using the PERCA technique ((Fleming et al., 2006) and references therein) were conducted as part of the Seasonal Oxidant Study (SOS) which covered three intensive measurement periods (27/02/2009 to $15 / 03 / 2009$ (SOS 1), 20/05/2009 to 02/06/2009 (SOS 2) and 02/09/2009 to 14/09/2009 (SOS 3)). $\mathrm{OH}$ and $\mathrm{HO}_{2}\left(\mathrm{HO}_{\mathrm{x}}\right)$ were detected by Laser-Induced Fluorescence spectroscopy using two FAGE (Fluorescence Assay by Gas Expansion) instruments (Heard and Pilling 2003). A ground-based FAGE was deployed during the RHaMBLe experiment May-June 2007 (Whalley et al., 2010) and an aircraft instrument (Commane et al., 2010; Ingham et al., 2009) was stationed at the observatory from February to December 2009, and made measurements in its ground configuration during the three intensive SOS periods, as described in Table 1.

Mixing ratios of halogen species ( $\mathrm{IO}, \mathrm{BrO}, \mathrm{OIO}$ and $\mathrm{I}_{2}$ ), nitrate $\left(\mathrm{NO}_{3}\right)$, formaldehyde $(\mathrm{HCHO})$ and glyoxal $(\mathrm{CHOCHO})$ were retrieved from long-path differential optical absorption spectroscopy (LP-DOAS) using the University of Leeds (UOL) LP-DOAS instrument (Plane and Saiz-Lopez 2006). The LP-DOAS instrument comprised a Newtonian telescope acting as a transmitter and receiver, and an array of retro-reflectors placed $6.1 \mathrm{~km}$ across a bay from the observatory (resulting in a total optical path length of $12.2 \mathrm{~km}$ ). Spectra were collected every $30 \mathrm{~s}$ and then further averaged over 20-30 min to improve the signal-to-noise ratio, resulting in detection limits of $0.5 \mathrm{pptv}$ for IO, $0.9 \mathrm{pptv}$ for $\mathrm{BrO}$ and 170 pptv for $\mathrm{HCHO}$. Detection limits of 15 pptv for $\mathrm{I}_{2}, 10$ pptv for OIO, 4 pptv for $\mathrm{NO}_{3}$ and 150 pptv for CHOCHO were estimated. The LP-DOAS instrument was based at Cape Verde for two periods; first during November 2006-June 2007, and second during October 2008-August 2009. In addition to the LP-DOAS, a Multi-Axis Differential Optical Absorption Spectroscopy (MAX-DOAS) instrument from the University of Heidelberg (UOH) has ran near continuously since November 2006. It contains a moveable telescope device with an integrated spectrometer which collects scattered sunlight from discrete elevation angles between $2^{\circ}$ and $40^{\circ}$, and in the zenith. The instrument measures the integrated concentration of species (SCD) along different lines of sight. The SCD are used to model the vertical distribution and concentration of the species (Deutschmann et al., 2011). The integration time for each of the seven measured elevation angle is 2 minutes which results in a total temporal resolution of 14 minutes and a detection limit of $4.4 \mathrm{pptv}$ for $\mathrm{BrO}, 1.5 \mathrm{pptv}$ for $\mathrm{IO}$ and $150 \mathrm{pptv}$ for $\mathrm{NO}_{2}$. From June to October 2010 additional LP-DOAS and in June 2010 also Cavity Enhanced (CE) - DOAS measurements were performed by the UOH. The applied LP-DOAS is a new fibre optic setup (Merten et al., 2011) which has a higher light throughput and thus allows a shorter total spectral sampling time of 1 minute. The instrument measures successively all wavelength ranges from $270 \mathrm{~nm}$ up to 680 $\mathrm{nm}$ and thus all relevant trace gases continuously. The absorption path for the measurements from June to October is the same as that from UOL, crossing the bay to the reflector in $6.1 \mathrm{~km}$ distance. As the instrument can automatically switch between different absorption light paths, during intensive field campaigns in June and October, additional measurements across half of the bay $(2.8 \mathrm{~km})$ to reflectors at different heights $(0 \mathrm{~m}, 45 \mathrm{~m}, 92 \mathrm{~m}, 560 \mathrm{~m})$ were performed to retrieve the vertical profile of the trace gases. The total measurement time using all reflectors and at all wavelengths was about 25 minutes. The resulting detection limits for the long absorption path are 0.6 pptv for IO, 0.8 pptv for $\mathrm{BrO}, 1 \mathrm{ppbv}$ for $\mathrm{O}_{3}, 30$ pptv for $\mathrm{NO}_{2}$ and 300 pptv for HCHO. The CE-DOAS is a broad band absorption cavity working in the spectral range from $430 \mathrm{~nm}$ to $460 \mathrm{~nm}$ and derives in situ trace gas concentrations of $\mathrm{IO}_{2} \mathrm{NO}_{2}$ and glyoxal $\left(\mathrm{C}_{2} \mathrm{H}_{2} \mathrm{O}_{2}\right)$. The instrument was setup at $\mathrm{CVAO}$, and during one day directly at the water front. Due to the high 
aerosol load from sea spray the detection limit is relatively high with 2 pptv for IO (5 minute resolution) and 1.5 ppt (50 minute resolution).

\subsection{Greenhouse gases $\left(\mathrm{CO}_{2}, \mathrm{CH}_{4}, \mathrm{CO}, \mathrm{N}_{2} \mathrm{O}, \mathrm{SF}_{6}\right)$ and oxygen}

The automated greenhouse gas measurement system integrates a Paramagnetic $\mathrm{O}_{2}$ analyser (Servomex Company Inc, PM1155), NDIR $\mathrm{CO}_{2}$ analyser (Siemens AG, Ultramat 6F) and a Gas Chromatograph (GC, Agilent Technologies, 6890A) with a Flame Ionization Detector (FID) used for $\mathrm{CH}_{4}$ and $\mathrm{CO}$ measurements and an Electron Capture Detector (ECD) for $\mathrm{N}_{2} \mathrm{O}$ and $\mathrm{SF}_{6}$ measurements. The measurement system occupies a contained air-conditioned laboratory with temperature typically stable to $\pm 0.2-0.5{ }^{\circ} \mathrm{C}$. A suite of calibration gas cylinders are kept horizontally in a thermally insulated enclosure (Blue Box) and shared between all the analysers. The details on the system's setup, operation, calibration and data quality control have been presented elsewhere (Kozlova and Manning 2009). The measurement system provides concentration data on a semi-continuous basis (one air measurement every 16 and 12 min for $\mathrm{O}_{2}$ and $\mathrm{CO}_{2}$ and for the GC species, respectively). The measurement system was installed in May 2008 and has been in operation (with periods of down time due to several technical problems) since October 2008. In addition to the continuous air measurements, flask samples have been collected mostly bi-weekly since March 2007. The flasks are shipped back to MPI-BGC where the air is subsequently analysed for $\mathrm{CH}_{4}, \mathrm{CO}, \mathrm{N}_{2} \mathrm{O}$ and $\mathrm{SF}_{6}$ concentrations, $\mathrm{O}_{2} / \mathrm{N}_{2}$ and $\mathrm{Ar} / \mathrm{N}_{2}$ ratios, and isotopic composition of $\mathrm{CO}_{2}\left(\delta^{13} \mathrm{C}_{-} \mathrm{CO}_{2}\right)$. The air inlets for both the continuous measurement system (inlets for $\mathrm{O}_{2}$ and $\mathrm{CO}_{2}$, and the $\mathrm{GC}$ species are separate) and the flask sampling unit are installed at $30 \mathrm{~m}$ (top of the tower), next to each other. An aspirated inlet has been installed on the $\mathrm{O}_{2}$ and $\mathrm{CO}_{2}$ sampling line to minimise the fractionation at the air intake (Blaine et al., 2006).

\subsection{Aerosol sampling, chemical and physical characterization}

\subsubsection{Aerosol sampling}

Aerosol is sampled at the top of a $30 \mathrm{~m}$ high tower to avoid the influence of surf-produced sea spray aerosol. IfTLeipzig sample continuously (since January 2007) using a high volume (HV) sampler equipped with a $\mathrm{PM}_{10}$ inlet (DHA-80, Digitel Elektronik AG, Switzerland), with samples collected on pre-heated quartz fiber filters $\left(110{ }^{\circ} \mathrm{C}\right.$ for $24 \mathrm{~h}, 150 \mathrm{~mm}$ Munktell, Sweden) at a flow rate of $500 \mathrm{~L} \mathrm{~min}^{-1}$. In addition, size-segregated aerosol samples were collected during six intensive campaigns $\left(17^{\text {th }}\right.$ May $-14^{\text {th }}$ June $2007,28^{\text {th }}$ November $2007-5^{\text {th }}$ January 2008 , $28^{\text {th }}$ June $-1^{\text {st }}$ August $2008,7^{\text {th }}$ January- $15^{\text {th }}$ February $2009,14^{\text {th }}$ May- $10^{\text {th }}$ June 2009, and January-February 2010) using a five stage Berner-type impactor with $50 \%$ cut-off sizes at $0.05,0.14,0.42,1.2,3.5$ and $10 \mu \mathrm{m}$. The particles were collected on pre-heated aluminum foils $\left(300{ }^{\circ} \mathrm{C}, 3 \mathrm{~h}\right.$ ) at a flow rate of $75 \mathrm{~L} \mathrm{~min}^{-1}$. For the metal analysis, a piece of Nuclepore polycarbonate foil was added on the aluminum foil (Wicom, Germany). Standard sampling duration was $72 \mathrm{~h}$ and $24 \mathrm{~h}$ during the intensive campaigns. The samples were stored at $-20^{\circ} \mathrm{C}$ until analysis.

The National Oceanography Centre, Southampton collected aerosol dust from the top of the $30 \mathrm{~m}$ tower using a low volume aerosol sampler in the period between July 2007 and October 2009. Samples were collected simultaneously onto four $47 \mathrm{~mm} 0.4 \mu \mathrm{m}$ pore-size membrane filters; two polycarbonate filters (Nuclepore) and two polypropylene filters (Sterlitech). Mass flow meters were used to measure the volume of air sampled through each filter. The filters were changed three times per week. Typical flow rates were $20-30 \mathrm{~L} \mathrm{~min}^{-1}$ per filter, giving total sample volumes of $50-100 \mathrm{~m}^{3}$. Samples were stored frozen $\left(-20^{\circ} \mathrm{C}\right)$ until analysis in the UK, as storage at aerosol solubility decreases when stored at room temperature (Buck et al., 2006) . 


\subsubsection{Chemical aerosol analysis}

Particle mass and total organic carbon content (TOC) were determined from the HV and Berner samples (Müller et al., 2009; Müller et al., 2010). Also, the non-purgeable organic carbon content (NPOC) was measured from the HV samples using a TOC-V CPH system (Shimadzu, Kyoto, Japan). Single compound analyses were done from the Digitel and Berner samples for more detailed aerosol characterization. The ions were determined from an aqueous filter extract using standard ion chromatography (IC) (Metrohm 690 and 761 Compact IC, Switzerland) (Müller et al., 2010). The organic anions including methanesulfonic acid (MSA) and smaller dicarboxylic acids were determined from an aqueous filter extract using capillary electrophoresis with UV-detection (CE-DAD) (Spectra Phoresis 1000, Thermo Separation Products, USA). Low molecular weight aliphatic amines were also determined from the aerosol samples. The amines were determined after a derivatization step using high performance liquid chromatography coupled to an electrospray ionization ion trap mass spectrometer (HPLC/ESI-ITMS) (Müller et al., 2009). In addition, the metal composition was characterized from the size segregated aerosol samples using total reflection X-ray fluorescence spectrometry (TXRF, Bruker AXS, Germany) (Müller et al., 2010).

The low volume samples were used to investigate the solubility of the aerosol dust constituent trace metals and nutrients $\left(\mathrm{NO}_{3}{ }^{-}, \mathrm{NH}_{4}{ }^{+}\right.$and $\mathrm{PO}_{4}{ }^{3-}$, dissolved organic carbon (DOC), dissolved organic nitrogen (TDN)), total chemical composition and mineralogy. Total chemical composition of the dust was investigated by total acid digestion of the polycarbonate filters followed by Inductively Coupled Plasma Mass Spectrometry (ICP-MS) analysis for a broad suite of metals. A simple ultrapure water leach was used with the polypropylene filters to investigate the readily soluble fraction of metals and nutrients in the samples. $100 \mathrm{ml}$ of ultrapure water was passed through the filter using a filtration apparatus and a small vacuum pump (Buck et al., 2006). The resulting filtrate was analysed for nutrients $\left(\mathrm{NO}_{3}{ }^{-}, \mathrm{NH}_{4}{ }^{+}\right.$, $\left.\mathrm{PO}_{4}{ }^{3-}, \mathrm{DOC}, \mathrm{DON}\right)$ using a standard nutrient autoanalyser, anions $\left(\mathrm{Cl}^{-}\right.$and $\left.\mathrm{SO}_{4}{ }^{2-}\right)$ using ion chromatography, high temperature combustion TOC-TDN analyser (TOC-V-CPN, Shimadzu), and a broad suite of metals measured using ICP-MS (Thermo, X-series).

\subsubsection{Physical Aerosol measurements}

Continuous measurements of particle number size distribution (PNSD), sampled from $30 \mathrm{~m}$, have been made since July 2008. A $30 \mathrm{~m}$ stainless steel tube leads from the tower to an air conditioned container housing the measurement equipment. (Prior to May 2007, aerosol was measured $4 \mathrm{~m}$ above ground and was highly influenced by sea spray; these measurements are not discussed here). The measurements in the size range of 0.01 to $0.8 \mu \mathrm{m}$ were conducted with a Scanning Mobility Particle Sizer (SMPS) (Wang and Flagan 1989). In parallel, an APS (TSI 3320, TSI Inc., St. Paul Minnesota, USA) was used to measure the aerodynamic size distribution in the size range of 0.6 to $10 \mu \mathrm{m}$. To combine the mobility size distribution from the SMPS and aerodynamic size distribution from the APS, a density and a shape factor depending on ambient conditions (dust or pure sea salt) were assumed and the aerodynamic diameters were converted to volume equivalent diameters (DeCarlo et al., 2004). Furthermore, volume and surface concentration as well as volume and surface size distributions can be extracted from the measurements, which is especially relevant for radiation information. 


\subsection{Dust modeling}

Satellite remote sensing is useful to characterize the spatiotemporal distribution of the Saharan dust plume and has also been used to estimate dust fluxes into the North Atlantic (Kaufman et al., 2005). However, a better understanding of the oceanic dust deposition processes including information about the origin of the dust aerosol and atmospheric processing is obtained from atmospheric dust transport models (e.g. Mahowald et al., (2005)). While global-scale dust models can provide information about averages and spatiotemporal variability of dust transport and deposition patterns, regional scale models are particularly suitable to investigate Saharan dust transport for specific meteorological situations.

Here we use the regional model system COSMO-MUSCAT to describe the input of Saharan dust into the tropical Atlantic (Heinold et al., 2007; Schepanski et al., 2009), using aerosol observations from the CVAO for model validation. The model system consists of the mesoscale meteorological model COSMO of the German Weather Service (Deutscher Wetterdienst, DWD) and the MUltiScale Chemistry Aerosol Transport Model (MUSCAT). For this application the domain includes the major part of the Sahara desert and extends to the Cape Verde islands, and the model operates with $28 \mathrm{~km}$ horizontal grid resolution and 40 vertical layers. Dust emission, transport, and deposition are simulated using meteorological and hydrological fields from the meteorological model, including the computation of the direct dust radiative effect on atmospheric dynamics. Dust emission fluxes cannot be observed directly, but are computed from simulated meteorological fields and compiled information on surface properties (vegetation cover, surface roughness, soil texture). The location of potential dust sources derived from Meteosat Second Generation satellite observations are taken into account for dust emission calculations. The simulated dust is transported as a passive tracer in several independent size classes between $0.1 \mu \mathrm{m}$ and $25 \mu \mathrm{m}$ radius. The model removes dust particles from the atmosphere by dry and wet deposition processes. Dry deposition (gravitational settling and turbulent mixing) depends on particle size, density and relevant meteorological parameters. The parameterization of wet deposition accounts for rain-out and wash-out. Dust particles removed from the atmosphere are then available at the ocean surface.

\subsection{QA/QC and Data management}

Data are supplied to the British Atmospheric Data Centre (BADC) on a monthly basis for $\mathrm{O}_{3}, \mathrm{CO}, \mathrm{NO}, \mathrm{NO}_{2}$, and meteorological data, or, for those data requiring extensive post processing (i.e. VOCs, o-VOCs, halocarbons, aerosol data), within 1 year of collection. Data are available immediately for public dissemination from the Data Centres upon registration.

In 2008 the site was accepted as a Global Atmospheric Watch (GAW)-contributing station for the gas phase species and was upgraded to a Global station in August 2009. Hourly data for carbon monoxide, ozone, $\mathrm{NO}_{\mathrm{x}}$ and $\mathrm{NO}_{\mathrm{y}}$ and meteorological parameters are submitted to the World Data Centre for Greenhouse Gases (WDGCC) (as well as to BADC) with the submission of these data on hourly, daily and monthly timescales and with measurements of VOCs and greenhouse gases to follow. In addition, the site is one of only a few existing stations which make long-term VOC measurements and as a result is integral in the set-up of the newly established GAW VOC network.

Calibrations for $\mathrm{O}_{3}, \mathrm{CO}$ and NMHCs are linked to the recognized GAW primary standards via the relevant Quality Assurance Science Activity Centre (QA/SAC) established by GAW. The QA/SAC provides support for the local quality assurance (QA) system under the guidelines and recommendations of the GAW Scientific Advisory Groups. 


\section{Results}

\subsection{Dispersion modelling of air mass history and their classification}

The UK Meteorological Office NAME dispersion model (Ryall et al., 2001) was used in passive tracer mode to study the origin and pathways of inert tracers (particles) arriving at the station's coordinates between October 2006 and September 2009. Ten-day air mass history footprints were calculated for three hourly periods and these have been integrated into monthly footprints in Figure 2 for 2008.

Seasonal changes in the air masses that influence the Cape Verde islands are evident, with a much greater influence of the Saharan region in the winter months (particularly December to February) and a greater number of trajectories originating from the Arctic and Europe in the spring and summer. The predominant wind direction of air masses in the last few hours before arriving at the site is from the north-east; this is almost exclusively the case during the summer months (June to October). Note that there are practically no air masses arriving from a southerly direction.

We have defined air mass origins into 5 broad originating regions, as shown in Figure 3 by assigning each $5^{\circ} \times 5^{\circ}$ box in the domain of interest to a region. These regions, which are similar to the air mass categories defined in (Lawler $e t$ al., 2009) and (Lee et al., 2009) are:

(i) Coastal African: Nearly all air masses pass over the coast of northwest Africa and hence the Mauritanian upwelling (Hagen 2001) before reaching the site

(ii) Polluted Marine: Air masses passing over Europe, particularly the Iberian peninsula

(iii) Saharan Africa: Dust, with influence from cities in Mauritania (Noaukchott) and Senegal (Dakar).

(iv) Atlantic: Further delineated into trajectories originating over the Atlantic (Atlantic marine) and over North America (Atlantic continental) during the previous 10 days

Finally, the four $5^{\circ} \times 5^{\circ}$ grid boxes surrounding the station were allocated to assign the local wind direction and to create a record of local influences due to air arriving outside of the NE sector or to very low wind speed conditions during NE winds. Less than $5 \%$ of air masses arrived from the SW and SE sectors. If the amount of particles originating from the NE $5^{\circ} \times 5^{\circ}$ grid ( \#6 in Figure 3) was over $30 \%$ of the total during the 10 day passageway (signifying low wind speeds) then this time stamp was also assigned a local flag (which occurred $19 \%$ of the time). The local index occurs more frequently in winter (September-February).

The model was run to capture any air masses arriving at the station in the lowest $100 \mathrm{~m}$ (ground level and in the boundary layer), so that any emissions released from the surface would be picked up by this air mass. From the $5^{\circ} \times 5^{\circ}$ grid divisions for each region in Figure 3, the percentage of particles passing over each of the five main sectors was calculated for every 3 hourly NAME output from October 2006 to September 2009.

All trajectories in their ten day journey pass over a combination of these sectors and a percentage distribution threshold was defined for each sector to assign it as being a significant influence on an air mass. For each sector a particle concentration of $10 \%$ of the maximum concentration found in that sector was used and this concentration was fed into a derived equation for each sector relating the concentration to its fractional contribution to the total. The final threshold 
contribution for each sector to be of significant influence was calculated to be 12, 4, 9, 3 and $16 \%$ for coastal African, European, African, American and Atlantic sectors respectively. This was calculated from $10 \%$ of the maximum particle concentration found in each sector over the three years so as not to bias the sectors that have the greatest number of particles passing over them (i.e. the sectors that are the most distant from the site, American and Europe, will be counted as contributing when their particle counts are lower than the Atlantic sectors).

For each 3 hour period, the sectors of influence were used to classify each period into 7 trajectory types. This classification method proved to be similar to the trajectory types found for Cape Verde using cluster analysis of back trajectories (Mace et al., 2011), an objective way of assigning trajectory types without assigning the different regions of interest. The trajectories were defined as:

1) Atlantic and African coastal - AAC,

2) Atlantic marine - AM,

3) North American and Atlantic - NAA,

4) North American and coastal African - NCA,

5) European (with minimal African influence) - EUR,

6) African (with minimal European influence) - AFR,

7) European and African - EUR/AFR.

Example trajectories are shown in Figure 5. These trajectory types were used to aid the analysis of differences in atmospheric composition, as discussed in section 3.6.

\subsection{Boundary layer height, radiation, meteorological conditions}

\subsubsection{Boundary Layer height}

The Atmospheric Boundary Layer (ABL) is defined as the part of the atmosphere directly influenced by the Earth's surface, often responding with a time scale of about one hour or less (Stull 1988). The ABL top is usually identified by a sharp increase in the potential temperature vertical profile (the inversion), and a decrease in humidity. Typical of the eastern sides of the Atlantic and Pacific in both hemispheres, air subsiding into the subtropical north-east Atlantic (in this case from further north and east) is warmer and drier than the air that has been in contact with the relatively cold ocean surface influenced by upwelling, and a strong inversion forms at the interface of the two air masses (Hanson 1991). These conditions are favourable for the formation of marine stratocumulus cloud decks. In this region, the (relatively patchy) marine stratocumulus cloudiness tends to peak in July and August due to changes of position and intensity of the Northern Hemisphere subtropical highs (Hanson 1991). Hanson (1991) also noted that months with cooler than normal sea surface temperatures (SST) also have more than normal cloudiness, suggesting that there may be a positive feedback between marine stratocumulus clouds and SST.

Here we define the depth of the ABL ( $h$, corresponding to the stratocumulus cloud top), as where the vertical gradient of virtual potential temperature $\left(\partial \theta_{v} / \partial z\right)$ first becomes greater than or equal to $3 \mathrm{~K} \mathrm{~km}^{-1}$ (Zeng et al., 2004). The potential temperature gradient was calculated from the NOAA ESRL radiosondes launched daily at 1200 (UTC) from 
the island of Sal, approx $200 \mathrm{~km}$ from the Cape Verde Observatory. Figure 6 shows a typical vertical profile of $\theta$ and relative humidity $(\mathrm{RH})$ - note that the contrast between the surface air and the air above the inversion is substantial. The cloud layer is taken as the layer where the relative humidity is larger than $90 \%$ - a relaxation of the $97 \%$ RH observed in broken cloud layers (Albrecht et al., 1985; Betts et al., 1995) due to the coarse resolution of the radiosonde data. Figure 6 compares $h$ determined from the radiosonde data with ceilometer measurements of cloud base height (CBH data shown are 10th percentile of 15 minute averages) measured at the CVAO during October 2007-August 2008. Given the coarse vertical resolution of the radiosonde data (of approx $\pm 50-80 \mathrm{~m}$ near $h$ ) and the apparently thin clouds (Figure 6), CBH is expected to approximate to $h$, assuming that the boundary layer forcings at Sal and São Vicente are near equivalent. Unfortunately only $~ 90$ days of radiosonde data were available over this period for comparison, but nevertheless Figure 6 shows close agreement between $\mathrm{CBH}$ and $h$. The data show a strong amount of variability in inversion height over timescales of days, varying from 300 to $1500 \mathrm{~m}$, according to the synoptic conditions. However, no overall seasonal or diurnal pattern is evident (daily mean CBH was $713 \pm 236 \mathrm{~m}$ ). A stratocumulus-topped marine boundary layer can exhibit strong diurnal modulation due to the intense longwave radiative cooling at the cloud-top during the night, feeding entrainment of air from the free-troposphere (Lilly 1968), and the shortwave heating of cloud top during the day, which acts to stabilize the MBL and reduce entrainment. However, in this region since no diurnal modulation in $h$ is apparent, we assume that there is no systematic difference between day-time and night-time entrainment rates.

\subsubsection{Radiation}

Spectral radiometer measurements for the $7^{\text {th }}$ March during the SOS 1 campaign as well as the variability in diurnal $J\left(\mathrm{O}^{1} \mathrm{D}\right)$ from radiometer measurements during SOS 1 are shown in Figure 7. The suite of species' photolysis rates have a $25 \%$ absolute error bar, owing to instrument damage and calibration difficulties during the deployment, whereas the relative error (over time) is only $3 \%$.

\subsubsection{Meteorological conditions}

Figure 8 shows solar radiation, wind speed and temperature and relative humidity variations from October 2006 until September 2009. Peak solar radiation occurs in May/June with maximum temperatures and relative humidity in September, whereas wind speed is variable throughout the year. Temperatures measured at CVAO over this period varied between $19.5{ }^{\circ} \mathrm{C}$ and $30.5{ }^{\circ} \mathrm{C}$, averaging $23.6^{\circ} \mathrm{C}$, and relative humidity varied between 56 and $93 \%$, averaging $79 \%$.

Wind direction was between 0 and $15 \mathrm{~m} \mathrm{~s}^{-1}$ (mean and standard deviation of $5.27 \pm 1.73$ ) and the predominant wind direction was from the north-east as shown in the 3 year monthly wind roses in Figure 9. Average diurnal cycles of temperature, pressure, solar radiation and relative humidity over this 3 year period are shown in Figure 10. The solar radiation diurnal maximum occurs at 1400 UTC, whereas the temperature shows a broader diurnal maximum peaking at 1500 UTC at $24.4^{\circ} \mathrm{C}$, with the mean night-time temperature only slightly lower at $23{ }^{\circ} \mathrm{C}$. 


\subsection{Aerosol composition and seasonality}

\subsubsection{Aerosol mass and major components}

Saharan dust transport towards the eastern North Atlantic shows strong seasonal differences. In summer, the dust layer is found as an elevated layer, moving in a westward direction. In winter, the dust layer is transported in a south-west direction and is situated at lower tropospheric levels, frequently depositing in the region of the Cape Verde archipelago (Chiapello and Moulin 2002; Schepanski et al., 2009).

A clear distinction between seasons is evident in the CVAO high volume and low volume aerosol samples. In Table $2 \mathrm{a}$ classification for mass concentrations collected on HV-filters was made according to season, although it should be noted that most samples were collected during the winter.

The ionic composition of the aerosol at Cape Verde is dominated by sea salt but in the two smallest particulate matter (PM) classes of the size-segregated samples $(<0.05$ and $<0.14 \mu \mathrm{m} 50 \%$ cut-off sizes $)$, non-sea salt components contributed to about $80 \%$ of the mass. Saharan dust and sea salt components were found mainly in the super-micron particles and less than $15 \%$ were found in sub-micron particles. Typical PM constitutions from the spring 2007 campaign are described in Müller et al., (2010).

Elemental (EC) and organic carbon (OC) were found in very low concentrations. In the smallest size fraction, OC is a major part of the PM but with increasing particle size the carbon content decreased strongly. The highest OC/EC ratios were found during dust events where continental air masses reached Cape Verde.

\subsubsection{Metal composition}

The metal composition from collected size-segregated samples also showed a strong seasonal variation with more crustal metals observed during the winter intensive campaigns as compared to the spring campaigns. Figure 12 shows the iron and total $\mathrm{PM}_{10}$ concentration (sum of all five stages) from the 5-stage Berner cascade impactor during a winter campaign. Spikes in the figure represent Saharan dust events while dips represents days of dominant sea spray. The iron concentration showed significant differences between non-dust events and dust events (ranging between a few $\mathrm{ng} \mathrm{m}^{-3}$ to $4 \mu \mathrm{g} \mathrm{m}^{-3}$ ), with iron constituting about $2 \%$ of the total aerosol mass. Most of the iron was found in larger particles i.e. of between $1.2-10 \mu \mathrm{m}$ diameter. The trajectory footprints as well as the $\mathrm{Fe} / \mathrm{Ca}$ and $\mathrm{Fe} / \mathrm{K}$ ratios were used as criteria to distinguish the contribution of sea spray and other sources to the collected aerosols. As expected, days with higher iron concentrations could be correlated with Saharan dust deposition while days with low iron concentrations were associated with marine trajectories. In addition to the total iron concentration of the $\mathrm{PM}_{10}$ masses, the soluble $\mathrm{Fe}$ (II) and Fe (III) content was also investigated using an ion chromatography system with post column derivatization. These analyses are performed only during intensive campaigns.

Total $\mathrm{Fe}$ and $\mathrm{Al}$ concentrations determined from the low volume sampler between July 2007 and July 2008 are shown in Figure 13, along with the fraction of particles originating from the Sahara as determined by the NAME model (section 3.1). Total atmospheric Fe concentrations varied between 0.005 and $33.4 \mu \mathrm{g} \mathrm{m}{ }^{-3}$, while total atmospheric $\mathrm{Al}$ concentrations ranged from 0.008 to $66.9 \mu \mathrm{g} \mathrm{m}^{-3}$, with the highest concentrations occurring during the winter months (from the beginning of November to early March). Aluminium is predominantly associated with crustal materials and is 
often used as a tracer of mineral dust in the surface ocean (Measures and Vink 2000). Figure 13 shows several intense dust events occurring between November 2007 and April 2008. The NAME model captures all of these events and thus we have confidence that it is correctly identifying the origin and pathways of air masses arriving at the CVAO, although clearly it cannot be used to predict the intensity of any specific dust event. During the summer months, several dust events of shorter duration and much weaker intensity can be observed. This is in line with expectations based on seasonal changes in the meteorological conditions around Cape Verde, as discussed above.

Dissolution experiments conducted using the ultrapure water leaching protocol resulted in the release of between 0.1 and $14.3 \%$ of the total $\mathrm{Al}$ and between 0.1 and $15.7 \%$ of the total $\mathrm{Fe}$ in the samples. An inverse relationship exists between the proportion of $\mathrm{Fe}$ and $\mathrm{Al}$ released and the atmospheric mineral dust concentration (using total $\mathrm{Al}$ concentrations as a proxy - data not shown), with much lower solubility measured at high atmospheric dust concentrations. This relationship is a common feature among aerosol solubility datasets and there is on-going scientific debate about its cause with indications that the relatively high surface area to volume ratio of smaller particles, which are dominant during periods of low dust loadings, yields a higher solubility (Baker and Croot 2010). There was also a strong correlation between soluble $\mathrm{Fe}$ and $\mathrm{Al}$, with a line of best fit given by $[\mathrm{Fe}]=(0.69 \pm 0.01) \mathrm{x}[\mathrm{Al}]+(0.5 \pm 0.7) \mathrm{x}$ $10^{-3} \mu \mathrm{g} \mathrm{m}^{-3} ; \mathrm{R}^{2}=0.95$. The different ratio of soluble $\mathrm{Fe}$ to $\mathrm{Al}(0.69)$ to the total composition $\left(\mathrm{Fe} / \mathrm{Al}=0.51 ; \mathrm{R}^{2}=0.998\right)$ suggests that the soluble fraction is dominated by minerals containing higher amounts of Fe relative to $\mathrm{Al}$ than the bulk material. For example, the strong correlation observed between soluble $\mathrm{PO}_{4}{ }^{3-}$ and soluble $\mathrm{Fe}\left(\mathrm{R}^{2}=0.62\right)$, indicates that the phosphate has a mainly crustal source.

A good agreement was observed in the temporal trends for $\mathrm{PM}_{10}$ total Fe concentrations in samples collected using the high volume sampler and the total Fe concentrations in samples from the low volume sampler during the same time period (28 $8^{\text {th }}$ November $2007-7^{\text {th }}$ January 2008) (Figure 14). Nevertheless, total Fe concentrations were significantly higher for the period of enhanced Fe concentrations between $26^{\text {th }}$ December and $5^{\text {th }}$ January, although the agreement was better at the lower Fe concentrations determined earlier in the period (see Figure 14). Some of this difference can be attributed to the difference between the $\mathrm{PM}_{10}$ and total suspended particle (TSP) size fractions. During periods of high mineral dust loading, there will be a greater number of larger particles, resulting in a decrease of the $\mathrm{PM}_{10}$ size fraction relative to TSP. However, there are experimental factors that make a simple comparison of these data difficult. The sample collection efficiency of a cascade impactor is typically lower (70 - 80\% of TSP values) than for systems sampling TSP especially during periods of high dust loadings. Also, the longer sampling duration used with the low volume sampler and a number of periods when no samples were collected using the 5-stage Berner cascade impactor mean that it is not possible to compare samples covering the exact same time period.

\subsubsection{Dicarboxylic acids and MSA in HV-samples}

Several low-molecular-weight dicarboxylic acids (DCAs) were determined from both the filter samples as well as sizeresolved impactor samples during the first intensive campaign. Oxalic acids were always found to be the most abundant DCAs with a mean concentration of $96 \mathrm{ng} \mathrm{m}^{-3}$ from filter samples. With increasing chain length, the mean concentrations of the DCAs decreased (malonic acid: $27 \mathrm{ng} \mathrm{m}^{-3}$, succinic acid: $11 \mathrm{ng} \mathrm{m}^{-3}$, glutaric acid: $3 \mathrm{ng} \mathrm{m}^{-3}$ ). Among the three hydroxylated DCAs (tartronic, malic, and tartaric acid), malic acid was the most abundant (mean during first intense from filter: $4 \mathrm{ng} \mathrm{m}^{-3}$ ), while the remaining two were hardly detected in the samples. 
The size distributions of DCAs showed a bimodal distribution for oxalic acid and coarse mode concentration maxima for the other DCAs. As discussed in Müller et al., (2010), such distributions are commonly observed for marine aerosols and attributed to a significant fraction of the DCAs in sea salt particles.

Methanesulfonic acid (MSA) was determined together with the DCAs and a mean concentration of $37 \mathrm{ng} \mathrm{m}^{-3}$ was found from the filter samples during the first intensive campaign (Figure 15). While a correlation with dimethyl sulphide (DMS) could not be established during that period, the MSA concentration closely followed that of nss-sulfate (Figure 15). The size distribution showed a maximum mean concentration in accumulation mode particles ( $\mathrm{Dp}_{\text {Aerosol }}=0.42-1.2$ $\mu \mathrm{m})$ and a similarly high concentration in sea salt particles $\left(\mathrm{Dp}_{\text {Aerosol }}=1.2-3.5 \mu \mathrm{m}\right.$, (Müller et al., 2010)).

\subsubsection{Amines}

From theoretical calculations (Barsanti et al., 2009; Kurten et al., 2008; Loukonen et al., 2010) and field measurements (Makela et al., 2001; Smith et al., 2010) it is assumed that low molecular weight aliphatic amines can be very important in the growing process of sulfuric acid clusters. Beside the influence on the physicochemical characteristics of small marine nss- $\mathrm{SO}_{4}{ }^{2-}$ particles, the amines are also relevant for the carbon and nitrogen cycle in the marine environment (Facchini et al., 2008). Aliphatic amines, namely methylamine (MA), dimethylamine (DMA) and diethylamine (DEA), were found in the highest concentrations on stage $2(0.14-0.42 \mu \mathrm{m})$ Berner impactor samples collected at the CVAO (Müller et al., 2009). The mean amine concentrations of the most abundant amines DMA and DEA varied between $270 \mathrm{pg} \mathrm{m}^{-3}$ in spring (Figure 15) to $830 \mathrm{pg} \mathrm{m}^{-3}$ in winter 2007. However, even though the exact amine source is not known, it seems that phytoplankton is one of the major amine sources in the marine environment. A strong connection of the amines to phytoplankton activity was observed for the subtropical North Atlantic especially during an unexpected winter algal bloom in 2007/2008 (Müller et al., 2009). But, a correlation to further indicators of an enhanced phytoplankton activity such as MSA wasn't found (Figure 15). Otherwise, there were two plausible processes identified which can be responsible for the enhanced algal growth in the winter months. These were the transport of nutrients to the surface water by local upwelling and the deposition of Saharan dust particles (3.3.2) (Müller et al., 2009).

\subsection{Dust modelling}

The COSMO-MUSCAT model results provide spatial context to the microphysical and chemical dust aerosol measurements at the CVAO. Saharan dust transport and deposition into the tropical Atlantic Ocean were simulated for dust transport events during 2007 and up until the beginning of 2009. The model results were evaluated with in situ aerosol measurements from the CVAO, satellite dust indices and sun photometer measurements that are routinely taken at the Aerosol Robotic Network stations downwind of major dust source regions. Initial detailed comparisons of modelled dust concentrations, optical thicknesses (AOT), and particle size distributions with observations at Cape Verde show promising agreement, indicating that the model reproduces size resolved dust deposition fluxes realistically. Comparisons of AOT time series show that the model captures individual dust transport events well. Such AOT observations have the limitation that they cannot provide information on the vertical layer structure of the dust transport. Over the Atlantic, dust aerosol is transported within the Saharan Air Layer, which is a well-defined layer with low relative humidity and high dust particle concentration. Areas where wet deposition is the dominant sink of atmospheric dust are mostly influenced by convective precipitation in the intertropical convergence zone. In the Cape 
Verde region, dry deposition processes of dust dominate during most of the year, but most pronounced in the northern hemisphere winter (Figure 16). In the northern hemisphere summer, dust transport occurs above the marine boundary layer at 3-5 km height, and dry deposition events over the ocean are related to sinking of air masses containing dust. During this season deposition fluxes in the Cape Verde region are lower than in the winter months (0.04-0.1 for summer compared to 0.1-0.2 in winter for dry deposition, from Figure 16) and influenced by both dry and wet processes, which occur sporadically. In contrast, Saharan dust transport in the winter months occurs in the boundary layer below $2 \mathrm{~km}$ height. The dust layer often extends down to the surface, which enhances dry deposition fluxes, while wet deposition of dust is very low in this area. In this season, when the dust layer is situated near the surface, high dust deposition rates coincide with high dust concentrations and high AOT values. In addition to providing information on the spatiotemporal distribution of dust deposition fluxes, such model results also point to the relevant dust deposition processes for specific dust events. Whether dust is removed from the atmosphere as dry particles or washed out by rain can influence the chemical properties of the dust particles that are deposited into the ocean surface.

\subsection{Greenhouse gases}

The continuous observations of the greenhouse gas concentrations and $\mathrm{O}_{2}$ exhibit synoptic events, which can be related to shifts in the trade wind system. The concentration signatures of such events are consistent with the expected signals from coastal upwelling waters. Figure 17 (right-hand side panel) shows atmospheric concentrations of $\mathrm{CO}_{2}, \mathrm{O}_{2}, \mathrm{CH}_{4}$ and $\mathrm{CO}$ for the month of January 2009. The $\mathrm{N}_{2} \mathrm{O}$ and $\mathrm{SF}_{6}$ concentration records over this period do not exhibit significant excursions, and are thus not shown in Figure 17. The data points are 2-hourly trimmed averages of the continuous measurements. Gaps in the time series reflect malfunctioning of the instruments caused by power failures (prior to the installation of backup power generators). The Atmospheric Potential Oxygen (APO), has also been calculated and shown in Figure 17 and represents the fraction of atmospheric $\mathrm{O}_{2}$ variations mainly driven by oceanic processes (Manning and Keeling 2006; Stephens et al., 1998).

The left-hand side panel in Figure 17 shows back trajectory analyses of two specific synoptic events superimposed on a map of ocean colour for January 2009, indicating monthly mean surface water chlorophyll content (from the GlobColor Project: http://www.globcolour.info). The back trajectories were computed with the HYSPLIT4 model (http://www.arl.noaa.gov/HYSPLIT.php). The colours denote trajectories before (blue), during (yellow) and after (green) the respective events. The time periods corresponding to the two synoptic events are shaded with the same colours in the right-hand side panel.

During the event of the $9^{\text {th }}-14^{\text {th }}$ January 2009 the back trajectories indicate a temporary shift of the air origin from the African coast and Canary Islands (blue and green trajectories) to the open Atlantic ocean (yellow trajectories) resulting in lower $\mathrm{CO}_{2}, \mathrm{CH}_{4}$ and $\mathrm{CO}$ concentrations, and higher $\mathrm{O}_{2}$ and APO. Conversely, during the event of the $20^{\text {th }}-27^{\text {th }}$ January the air masses arriving at the site were passing over the upwelling area off Western Sahara (yellow trajectories) associated with elevated $\mathrm{CO}_{2}$ and lower $\mathrm{O}_{2}$ and $\mathrm{APO}$ concentrations. Unfortunately, $\mathrm{CH}_{4}$ and $\mathrm{CO}$ measurements are unavailable for this synoptic event owing to the technical problems with the instrument. Qualitatively, the observed synoptic variations reflect the expected signatures of air-sea exchanges in the upwelling areas, which are characterised by supersaturated $\mathrm{CO}_{2}$ and $\mathrm{CH}_{4}$ and depleted oxygen (Kock et al., 2008; Stramma et al., 2008). 
The atmospheric measurements are complemented by regular surface ocean measurements performed upstream of the CVAO at the Cape Verde Oceanic Observatory (CVOO: $17.59^{\circ} \mathrm{N}, 24.25^{\circ} \mathrm{W}$ ). The combination of the atmospheric and oceanic measurements at CVAO provides a unique opportunity for the long-term monitoring of a major section of the West African upwelling zone.

\subsection{Reactive trace gases}

\subsubsection{Seasonal and sector trends of $\mathrm{O}_{3}, \mathrm{CO}$, VOCs and $\mathrm{NOx}$}

Time series of daily averaged $\mathrm{O}_{3}, \mathrm{CO}$, NOx, NOy, propane, ethane, acetylene, acetone and methanol mixing ratios are shown in figure 18 , plotted in UTC time (local +1 hour).

$\mathrm{O}_{3}$ displays a broad early spring maximum of 40-50 ppbv and a minimum in late summer of 10-25 ppbv, data which is consistent with other remote MBL Northern Hemisphere sites (Monks et al., 2000; Savoie et al., 1992; Simmonds and Derwent 1991). CO and ethane levels also show spring maxima and summer minima. The CO data are very similar to measurements obtained through the NOAA flask sampling network at Azores ( $39^{\circ} \mathrm{N}, 27^{\circ} \mathrm{W}$ ) (Holloway et al., 2000), a site similarly influenced by Northern Hemispheric emissions. Despite having a similar atmospheric lifetime to CO, thought to be dominated through reaction with $\mathrm{OH}$, ethane shows a narrower maximum and much larger amplitude in its seasonal cycle. As discussed in (Read et al., 2009) from the analysis of 2007 data, we attribute this difference in seasonal amplitude to summer time photochemical sources of $\mathrm{CO}$ such as oxidation of methane and OVOCs; the impact of secondary production on $\mathrm{CO}$ concentrations is likely to be highly relevant for the budget of this species but the current uncertainty from this source is at least a factor of three (Holloway et al., 2000, Read et al., 2009). Oxidation of ethane by $\mathrm{Cl}$ atoms may also play a role (Lawler et al., 2009) in the higher seasonal amplitude of ethane concentrations if $\mathrm{Cl}$ oxidation occurs predominantly in summer. The OVOCs acetone and methanol show a broad summer maximum although with a large amount of seasonal variability.

$\mathrm{NO}_{\mathrm{x}}$ levels display a seasonal cycle, where it is generally higher during January and February and again in November and late December, as also shown by (Lee et al., 2009) who analysed $2007 \mathrm{O}_{3}$ and $\mathrm{NO}_{\mathrm{x}}$ data. This is believed to be mainly due to increased influence of African air masses during this time, rather than photochemistry, reflecting the increased $\mathrm{NO}_{\mathrm{x}}$ transported from the African continent, as well as $\mathrm{NO}_{\mathrm{x}}$ that may be locally produced from transported reservoir species (e.g. PAN or $\mathrm{HNO}_{3}$ ). The AFR air mass trajectories (Figure 5) mostly originate from too far north to pick up substantial biomass burning, soil or lightning emissions of $\mathrm{NO}_{\mathrm{x}}$ (Richter and Burrows 2002; Yienger and Levy 1995), CO and NMHC (Bechara et al., 2010; Gros et al., 2004; Hao et al., 1996) from the north African savannahs (Figure 19), although an influence from these sources cannot be ruled out. The west African coastal cities of Dakar and Nouakchott as well as higher ship emissions from the north-east to easterly sectors, are also likely to influence $\mathrm{NO}_{\mathrm{y}}$ and $\mathrm{NO}_{\mathrm{x}}$ levels observed at Cape Verde. Anthropogenic emissions from coastal cities such as Dakar are advected in generally clear air and at low levels towards Cape Verde. This transport pathway contrasts markedly with that of $\mathrm{NO}_{\mathrm{x}^{-}}$ rich air masses associated with African soil emissions. Soil-emitted $\mathrm{NO}_{\mathrm{x}}$ from the Sahel is stimulated by heavy rainfall events and in particular those associated with the monsoonal period (Stewart et al., 2008). In these conditions, when highly convective weather systems dominate, transport from the surface to the free troposphere via convective clouds is the dominant pathway. These conditions loft surface $\mathrm{NO}_{\mathrm{x}}$ higher in the free troposphere such that they rarely intersect with surface measurements at Cape Verde. 
$\mathrm{NO}_{2}$ concentrations measured by the UOH MAXDOAS were usually below the detection limit of 150 pptv. Peak concentrations above the detection limit were observed during southerly/local air masses and were also detected with the University of York $\mathrm{NO}_{2}$ data (data not shown).

Whilst a detailed analysis of trends is outside the scope of this paper, we note that $\mathrm{NO}_{\mathrm{x}}$ levels appear to have slowly increased whilst $\mathrm{O}_{3}$ and ethane levels were slightly lower in the spring of 2008 (32.9 \pm 7.0 ppbv and $993.1 \pm 289.2$ pptv) than in 2007 ( $38.8 \pm 5.3$ ppbv and $1205.5 \pm 285.3$ pptv) and $2009(37.4 \pm 5.4$ ppbv and $1055.2 \pm 277.1$ pptv). Meanwhile CO in spring had decreased from $117.2 \pm 12.0$ to $109.0 \pm 14.0$ to $105.7 \pm 9.0$ ppbv between 2007, 2008 and 2009. A Northern hemisphere decrease in many non-methane hydrocarbons (between 1-5 \% $\mathrm{yr}^{-1}$ ) has been seen at many locations (Helmig et al., 2009) and data from CVAO appear to show a similar trend.

Despite all of the air masses arriving from a north-east direction (hence the position of the station on the northeast of the northern-most island in Cape Verde) and with processing occurring in the MBL for typically several days prior to arrival, the comparison of average chemical mixing ratios and their standard deviations for the seven predominant air mass types, as shown in Table 3, reveals small differences arising from the influence of relatively longer-lived sources or precursors. Some months did not experience all of the seven air mass types so do not have an average composition level.

Ozone levels were generally highest in the North American influenced air masses, reflecting relatively high levels of precursor emissions including ethane, propane, and $\mathrm{CO}$ from North American sources. For a given $\mathrm{NO}_{2}$ level, higher ambient VOC concentrations will lead to ozone formation initiated by the peroxy radical $\left(\mathrm{RO}_{2}\right)+\mathrm{NO}$ reaction, whereas lower VOC concentrations will increase the relative importance of the $\mathrm{OH}+\mathrm{NO}_{2}$ reaction, thereby favouring $\mathrm{HNO}_{3}$ formation. Figure 20 shows an example of $\mathrm{CO}$ and $\mathrm{O}_{3}$ enhancement of up to $137 \mathrm{ppbv}$ and $50 \mathrm{ppbv}$, respectively, during two periods of North American influence in early 2009.

In winter, ozone levels are similarly high in European (EUR) and North American and African coastal (NCA) air masses (whereas in summer, levels in European air masses are $10 \%$ lower in $\mathrm{O}_{3}$ than in American air masses). This is likely be related to the different relative amounts of NMHC in winter and in summer: ethane levels were $38 \%$ higher in NAA compared to EUR trajectories in summer but only $11 \%$ higher in winter. In contrast, acetone and methanol were most abundant in AFR/EUR air in summer. Coastal/upwelling sources also appear to be important for these compounds. Minimum levels of ozone are in the Atlantic marine section (AM), which has no continental input for at least 10 days prior to arrival, and the African sector (AFR) in summer time. This is presumably because this sector is less photochemically aged than EUR and NAA air masses, as shown by the relatively high ratio of alkenes to alkanes and low levels of methanol (the latter associated with secondary processing of hydrocarbons) in summertime AFR air. There is also a likely influence of dust, which is a well known sink of $\mathrm{O}_{3}$ (see section 3.4).

$\mathrm{NO}_{2}$ levels were highest in the African and European air masses (AFR, EUR and EUR/AFR). $\mathrm{NO}_{\mathrm{y}}$ showed a similar pattern but with a greater enhancement in air masses with a Saharan origin (AFR). These trends are very similar to those found using back trajectory classifications (Lee et al., 2009) and using cluster analysis of back trajectories (Mace et al., 2011). The short lifetime of $\mathrm{NO}_{\mathrm{x}}$ means that the local mixing ratio does not give a representation of its average level during transport. The transport of nitrogen in air masses from the US to Europe is often in the form of PAN and $\mathrm{HNO}_{3}$. 
These may undergo decomposition within long-range plumes re-releasing $\mathrm{NO}_{\mathrm{x}}$, particularly for PAN as air masses descend and reach higher temperatures. For air arriving at CVAO in summer, decomposition of PAN can be considered to be effectively complete. Previous measurements of PAN in the mid-Atlantic indicated mixing ratios ranging from more than 3 ppbv above $7 \mathrm{~km}$, to below 5 pptv in the marine boundary layer (Lewis et al., 2007). This study showed that the presence of $\mathrm{NO}_{\mathrm{x}}$ in the early and later stages of a plume trajectory typically resulted in significant elevation in ozone in the mid Atlantic, albeit with very low in situ $\mathrm{NO}_{\mathrm{x}}$ detected when measurements were made in the MBL.

\subsection{2 $\mathrm{O}_{3} / \mathrm{CO}$ ratios: Influence of air mass origin and dust}

Ozone to $\mathrm{CO}$ ratios have previously been used to estimate the amount of $\mathrm{O}_{3}$ exported to the North Atlantic troposphere from North America (Parrish et al., 1993; Parrish et al., 1998). With a tropospheric lifetime of about 2 months, CO is a long-lived tracer of anthropogenic sources and therefore can help to differentiate between $\mathrm{O}_{3}$ sources. The $\mathrm{O}_{3} / \mathrm{CO}$ ratios observed at the CVAO, shown in Figure 21, range between 0.3-0.45, very similar to the 0.3-0.4 observed at the Azores (Parrish et al., 1998). The $\mathrm{O}_{3} / \mathrm{CO}$ ratios are higher in the African and European air masses. At a remote site such as Cape Verde, $\mathrm{O}_{3}$ and $\mathrm{CO}$ enhancements are due to changes in air mass origin and mixing, rather than local emissions of $\mathrm{CO}$ and subsequent $\mathrm{O}_{3}$ formation. Real et al., (2008) noted that the $\mathrm{O}_{3} / \mathrm{CO}$ ratio in a polluted air parcel decreases as it ages and is transported further from the $\mathrm{CO}$ and $\mathrm{O}_{3}$ source. The remote low latitude marine boundary layer is generally a region of low nitrogen oxide levels and high sunlight and water vapour, and thus rapid photochemistry. In such regions, ozone and $\mathrm{CO}$ are simultaneously removed by photochemical processing, and aged tropical marine air (containing very low levels of nitrogen oxides) is expected to be more depleted in $\mathrm{O}_{3}$ than $\mathrm{CO}$ because of its shorter lifetime. The slope of the $\mathrm{O}_{3} / \mathrm{CO}$ ratio at Cape Verde, as observed in different air masses, correlates positively with the median $\mathrm{NO}_{\mathrm{y}}$ level $\left(\mathrm{R}^{2}=0.77\right.$, data not shown $)$.

The heterogeneous reaction of $\mathrm{O}_{3}$ (and of $\mathrm{HNO}_{3}$ and sulphate) on mineral dust aerosol is well established by laboratory studies (Fenter et al., 1995; Hanisch and Crowley 2003, 2001). A number of global modelling studies have simulated the effect of mineral dust on $\mathrm{O}_{3}$, and find that uptake of $\mathrm{HNO}_{3}$ and $\mathrm{O}_{3}$ near and downwind of the Sahara result in $\mathrm{O}_{3}$ reductions of between $8.5 \%$ and $25 \%$ (Bauer et al., 2004; Bian and Zender 2003; Liao and Seinfeld 2005; Tie et al., 2005). Mineral dust is also predicted to significantly reduce current nitrate and sulphate burdens (by about $85 \%$ and by 50-70 \% respectively near the Sahara (Dentener et al., 1996; Liao and Seinfeld 2005). The reduction in sulphate and nitrate concentrations and associated aerosol water near the Sahara means that the presence of dust is calculated to decrease top-of-atmosphere (TOA) cooling by anthropogenic aerosols by about $0.5-1 \mathrm{~W} \mathrm{~m}^{-2}$ (Liao and Seinfeld 2005).

In order to investigate the effect of dust on $\mathrm{O}_{3}$ at Cape Verde, we plot $\mathrm{O}_{3}$ vs $\mathrm{CO}$ mixing ratios in only the AFR and AFR/EUR trajectory types coloured according to the time spent over the Saharan region (Figure 22). Overall, it is clear that there is more variation in the $\mathrm{O}_{3} / \mathrm{CO}$ ratio in African compared to marine air. This could be due to greater variation in $\mathrm{O}_{3}$ sources and/or in $\mathrm{O}_{3}$ sinks, including dust uptake and also $\mathrm{O}_{3}$ photodecomposition which will vary according to the amount of dust in the atmospheric column. The $\mathrm{O}_{3} / \mathrm{CO}$ slope is significantly lower (0.13) for air mass trajectories with more than $40 \%$ of their time spent over the Saharan region (note that the threshold for assigning significant African influence is $9 \%$ ). The results imply that in these air masses, there is a reduction of $\sim 20 \% \mathrm{O}_{3}$ at $\sim 150$ ppbv $\mathrm{CO}$ (Figure 22) compared to air masses with a lower influence from the Sahara. However a significant positive offset in $\mathrm{O}_{3}$ is apparent such that at low $\mathrm{CO}$ concentrations, these air masses are associated with higher $\mathrm{O}_{3}$ levels than air with a low likelihood of dust input. Respective mean $\mathrm{NO}_{\mathrm{y}}$ values for air mass trajectories with less than $20 \%$, more than $20 \%$, and 
more than $40 \%$ of their time spent over the Saharan region were 363, 462 and 507 pptv, thus the increasing offset at higher dust influence could be due to increased photochemical production of $\mathrm{O}_{3}$ during ageing due to higher $\mathrm{NO}_{\mathrm{x}}$ levels. It is not clear whether the correlation between $\mathrm{NO}_{\mathrm{y}}$ and time spent over the Sahara is due to a direct effect of the dust or an increased influence from African $\mathrm{NO}_{\mathrm{x}}$ sources, either anthropogenic or biogenic (see section 3.6.1). If the former, this would indicate that the net result of the mineral dust is to increase the burden of $\mathrm{NO}_{\mathrm{y}}$, rather than a decrease through uptake of $\mathrm{HNO}_{3}$.

Measurements of methanol and acetone as shown in Figure 18 show a continual presence in this region. Their seasonal variation differs from that of their precursor NMHC (and primary source counterparts), with increased concentrations also observed during the summer months. The impact on $\mathrm{CO}$ concentrations through their secondary production has yet to be quantified but is likely to be highly relevant for the budget of this species with the current uncertainty from this source being at least a factor of 3 (Holloway et al., 2000; Read et al., 2009).

\subsection{Photochemical processing: $\mathrm{HO}_{\mathrm{x}}$ radicals}

\subsubsection{FAGE $\mathrm{HO}_{2}$ and PERCA $\Sigma_{\mathrm{i}}\left(\mathrm{HO}_{2}+\mathrm{R}_{\mathrm{i}} \mathrm{O}_{2}\right)$ measurements}

The warm, humid conditions and high solar irradiance experienced in the tropics lend themselves favourably to the formation of $\mathrm{OH}$ radicals such that peak concentrations can be as much as an order of magnitude higher than the global mean of $\sim 10^{6}$ molecule $\mathrm{cm}^{-3}$ (Bloss et al., 2005). In fact, it has been estimated that about $80 \%$ of methane, the third most abundant greenhouse gas (second only to $\mathrm{CO}_{2}$ of the long-lived greenhouse gases in terms of radiative forcing (Forster 2007), is oxidised in the troposphere between $30^{\circ} \mathrm{N}$ and $30^{\circ} \mathrm{S}$ through its reaction with $\mathrm{OH}$, with as much as $25 \%$ of the total occurring in marine regions (Bloss et al., 2005). Reliable, long-term measurements of $\mathrm{OH}$ in tropical areas are, therefore, of crucial importance for the understanding of the global oxidizing capacity of the troposphere and consequently the factors influencing climate change. However, up until recently, there have been relatively few measurements of $\mathrm{HO}_{x}$ (i.e. $\mathrm{OH}$ and $\mathrm{HO}_{2}$ ) in tropical regions compared to in polar or mid-latitude areas, and none over a time-span sufficient to investigate their seasonality. Peroxy radicals $\left(\mathrm{HO}_{2}+\Sigma_{\mathrm{i}} \mathrm{R}_{\mathrm{i}} \mathrm{O}_{2}\right)$ are key intermediates and chain carriers in the photochemical cycling of ozone in the troposphere e.g. (Monks 2005). Peroxy radicals are formed via the oxidation (mainly by $\mathrm{OH}$ ) of anthropogenic and biogenic species in the atmosphere such as $\mathrm{CO}, \mathrm{CH}_{4}$ and other organic compounds. Ozone is produced via the peroxy radical catalysed oxidation of $\mathrm{NO}$ to $\mathrm{NO}_{2}$ and subsequent photolysis of $\mathrm{NO}_{2}$, whilst ozone can also be destroyed through reaction with $\mathrm{HO}_{2}$ (Monks 2005). Owing to the short lifetime of peroxy radicals $\left(\mathrm{HO}_{2}\right.$ has a lifetime on the order of a minute in clean air, much less than a minute in polluted air (Monks 2005)), they give a good indication in combination with NO of in situ photochemical ozone production and loss. In addition, the self- and cross-reactions of peroxy radicals to form peroxides (e.g. $\mathrm{H}_{2} \mathrm{O}_{2}$ ) are a major sink for $\mathrm{HO}_{2}$ and $\mathrm{OH}$ (Reeves and Penkett 2003).

$\mathrm{HO}_{\mathrm{x}}$ measurements made by the FAGE instrument during the May-June 2007 RHAMBLE period are reported in Whalley et al., (2010). Maximum concentrations of $\mathrm{OH}$ and $\mathrm{HO}_{2}$ were $9 \times 10^{6}$ molecule $\mathrm{cm}^{-3}$ and $6 \times 10^{8}$ molecule $\mathrm{cm}^{-}$ ${ }^{3}$, respectively. A decrease in daily peak $\left[\mathrm{HO}_{2}\right]$ was observed, coinciding with a decrease in $\mathrm{CO}$ concentrations and a shift in the sampled air mass originating from the western north Atlantic (AM) and continental America (NAA) to air from Southern Europe and the Mediterranean (EUR). A modelling study based on the Master Chemical Mechanism (MCM) showed that the observations could be reproduced to within the $20 \%(1 \sigma)$ uncertainties if aerosol uptake and 
the chemistry of $\mathrm{IO}$ and $\mathrm{BrO}$ were considered. The model was most sensitive to changes in the aerosol parameters and the concentrations of $\mathrm{BrO}, \mathrm{IO}$ and formaldehyde.

During the SOS campaigns in 2009, the February-March period had an average temperature of $\sim 21{ }^{\circ} \mathrm{C}$ with some days of significant cloud cover and periods of short, light rain showers. The June measurement period was driest, with an average temperature of $\sim 23{ }^{\circ} \mathrm{C}$ whereas the September period had diverse weather conditions with days of torrential rainfall (for example, $\left.14-15^{\text {th }}\right)$ interspersed with some days of strong sunlight and higher average temperatures $\left(\sim 30^{\circ} \mathrm{C}\right)$. The highest peak values of $J\left(\mathrm{O}^{1} \mathrm{D}\right)$ were observed during this period.

The median diurnal profiles of hourly-averaged FAGE $[\mathrm{OH}],\left[\mathrm{HO}_{2}\right],\left[\mathrm{HO}_{2}\right] /[\mathrm{OH}]$ and $J\left(\mathrm{O}^{1} \mathrm{D}\right)$ (as recorded by the University of Leeds (UOL) radiometer) for each of the three SOS campaigns and the RHaMBLe campaign are plotted in Figure 23; the error bars are one standard deviation of the hourly-averaged $[\mathrm{OH}]$ and $\left[\mathrm{HO}_{2}\right]$, and for clarity, are only shown for SOS 2 and RHaMBLe, which were measured at similar times of the year. The daytime concentrations of both $\mathrm{OH}$ and $\mathrm{HO}_{2}$ tended to increase through 2009 (i.e. SOS $3>\operatorname{SOS} 2>\mathrm{SOS}$ ), consistent with the increase in parameters key to their formation (e.g. $\mathrm{J}\left(\mathrm{O}^{1} \mathrm{D}\right)$ and $\mathrm{H}_{2} \mathrm{O}$ ). $\mathrm{HO}_{2}$ concentrations were on average higher, and $\mathrm{OH}$ slightly lower, during SOS 2 compared to the 2007 RHaMBLe data, and consequently the daytime $\left[\mathrm{HO}_{2}\right]:[\mathrm{OH}]$ ratio observed during SOS 2 was about twice that of RHaMBLe. However, it should be noted the concentrations of each species during June 2007 and 2009 were within the respective $1 \sigma$ day-to-day variability represented by the error bars. This agreement could suggest that there may have been similar influences (e.g. levels of halogen oxides, aerosols) on $\mathrm{HO}_{\mathrm{x}}$-budgets at the site during both timeframes. The full statistical and modelling analyses of the 2009 dataset will investigate in more detail the factors causing the seasonal and day-to-day variability of $\mathrm{HO}_{\mathrm{x}}$ and their consequent impact on atmospheric processes (Vaughan et al., 2011 in preparation).

Figure 23D shows the mean hourly average diurnal cycle $\mathrm{HO}_{2}+\Sigma_{\mathrm{i}} \mathrm{R}_{\mathrm{i}} \mathrm{O}_{2}$ measurements made by the PERCA instrument during the three SOS intensive periods. Similarly to Figure 23B, the diurnal cycles show a classical bell shape with a slight asymmetry ascribed in previous low $\mathrm{NO}_{\mathrm{x}}$ marine boundary layer studies to the persistence of $\mathrm{RO}_{2}$ radicals (Monks et al., 1996) into the night owing to the relative rates of radical cross and self-reactions. It is clear that the maxima in radical concentration scales with season. The maxima in $J\left(\mathrm{O}^{1} \mathrm{D}\right)$ (measured by $\mathrm{UOL}$ ), the primary driver for radical production in the remote marine boundary layer were $3.28 \times 10^{-5} \mathrm{~s}^{-1}, 3.58 \times 10^{-5} \mathrm{~s}^{-1}$ and $3.84 \times 10^{-5} \mathrm{~s}^{-1}$ during SOS $1, \operatorname{SOS} 2$, and SOS 3.

Both the FAGE and PERCA instruments showed a similar trend in increasing concentrations of peroxy radicals from SOS 1 through to SOS 3 (although it must be noted that the two instruments did not run simultaneously during SOS 2 because of technical difficulties with the FAGE set-up). The maximum contributions of $\mathrm{HO}_{2}$ (as measured by FAGE) to the hourly-averaged daytime budget of total peroxy radicals (as measured by PERCA) were $40 \%, 45 \%$ and $34 \%$ for SOS 1, 2 and 3, respectively. Measurements in the Borneo rainforest in 2009 in the OP3 campaign (Hewitt et al., 2010) gave $\mathrm{HO}_{2} / \mathrm{HO}_{2}+\mathrm{RO}_{2}$ an average ratio of $15 \%$ for day light hours (Arunasalam personal communication), similar to the approximate $10 \%$ daily maximum ratios during the OOMPH Southern Ocean cruise (Hosaynali Beygi et al., 2011) but daylight ratios at Mace Head, Ireland were between 10 and $40 \%$ on low $\mathrm{NO}_{\mathrm{x}}$ days and up to $70 \%$ on high $\mathrm{NO}_{\mathrm{x}}$ days in summer 2002 (Fleming et al., 2006). 
The PERCA data show that $\mathrm{RO}_{2}$ persisted through the night-time, up to levels of $\sim 10$ pptv. The FAGE system was only able to be run through one night, during SOS 3. Low levels of $\mathrm{HO}_{2}(<1 \mathrm{pptv})$ were observed that evening implying that $\mathrm{HO}_{2}$ contributed less than $10 \%$ of the night time peroxy radical budget, at least for that night. This is as expected in the clean marine boundary layer, where the lifetime of $\mathrm{RO}_{2}$ at night (with $\mathrm{NO}$ absent) is much longer than that of $\mathrm{HO}_{2}$, as discussed above (Monks et al., 1996). Whalley et al., (2010) also observed low night-time levels of $\mathrm{HO}_{2}(\sim 0.6$ pptv) during RHaMBLe. However, these levels were significantly higher than night-time levels predicted by the MCM, and those authors showed that air masses with a high content $(\sim 100 \mathrm{ppt})$ of peroxyacetyl nitrate (PAN) could reproduce their night-time observations. This conclusion remains untested due to a lack of seasonal PAN measurements at the CVAO, although PAN concentrations as high as 120 pptv were observed by (Jacobi et al., 1999) during a cruise off the west coast of Africa, north of $10^{\circ} \mathrm{N}$.

In the clean atmosphere around Cape Verde, formaldehyde ( $\mathrm{HCHO}$ ) is also important for the $\mathrm{HO}_{\mathrm{x}}$ budget. LP-DOAS observations show that typical $\mathrm{HCHO}$ mixing ratios ranged between 350-550 pptv, with several events of high $\mathrm{HCHO}$ up to $1885 \pm 149$ pptv (Mahajan 2011 submitted). The data indicate a lack of strong annual or diurnal trend within the uncertainty of the measurement. The observed levels of $\mathrm{HCHO}$ are below the detection limit of satellite observations at this altitude, even during the high $\mathrm{HCHO}$ episodes. Modelling results suggest that the typical diurnal profile and monthly mean values can be replicated well using the methane and NMHC observations and that on average $20 \%$ of $\mathrm{HO}_{2}$ production and $10 \%$ of $\mathrm{OH}$ destruction can be attributed to the mean $\mathrm{HCHO}$ levels (Mahajan 2011 submitted; Whalley et al., 2010).

\subsection{Halogen chemistry}

IO and $\mathrm{BrO}$ were observed ubiquitously during the day by the UOL LP-DOAS with daytime (0900-1700 GMT) mixing ratios plateauing at around 1.5 pptv IO and 2.5 pptv BrO during the first period (November 2006 - June 2007) (Mahajan et al., 2010; Read et al., 2008). The seasonal changes for both species were within the variability of the dataset. Detailed 1-D modelling of the sources of halogens and their impact on the boundary layer chemistry by Mahajan et al., (2010) indicates that the $\mathrm{IO}$ and $\mathrm{BrO}$ account for up to $45 \%$ of the observed $\mathrm{O}_{3}$ destruction at the surface around Cape Verde. In addition, we suggest that an extra iodine source from the surface is necessary and is most probably photolysis dependent (Mahajan et al., 2010), because the observed fluxes of iodocarbons account for only 10$25 \%$ of the observed IO (Jones et al., 2010). The modelling work also indicated a strong vertical gradient in the IO mixing ratios, with the value at $500 \mathrm{~m}$ falling by $90 \%$ compared to the observed surface IO.

The retrieved University of Heidelberg UOH MAX-DOAS BrO values were under the detection limit of 4.4 pptv. The IO concentrations were comparable with the UOL LP DOAS results (Read et al., 2008). Vertical profiles of IO retrieved from the UOH MAX-DOAS measurements indicate that IO is present in a shallow layer with a vertical extent ranging between 100 and $500 \mathrm{~m}$, in agreement with the modelling discussed above. The daily averaged IO concentration at the surface as determined from the MAX-DOAS data was of the order of $1.5 \mathrm{pptv}$. This value is however the subject of substantial, currently not completely understood, uncertainties owing to the limited information on the viewing conditions. In contrast to both the UOH MAX-DOAS measurements and the UOL LP-DOAS measurements, data from UOH LP-DOAS measurements performed from June-October 2010 show no IO values above the detection limit of typically 0.6 pptv. Also, CE-DOAS observations in June 2010 show no IO concentrations above 
the detection limit of typically 2 pptv. A reason for the lower IO levels than observed by UOL may be due to changed atmospheric conditions or measurement errors. Further studies on the different observed IO levels are necessary. LPDOAS BrO concentrations are in good agreement with UOL observations, with daytime averages of 3.0 pptv (Figure 24), but with strong variations from day to day, peak concentrations in the morning and evening, and a clear minimum at noon. However, the morning and evening peak occur at different times from day to day due to different metrological conditions and are not apparent in the mean daily concentrations over the 9 day measurement period. Peak mixing ratios of up to 6 pptv were observed on several days between June and October 2010. The vertical UOH LP-DOAS distributions (using reflectors at different heights) show a well mixed $\mathrm{BrO}$ layer within the lower $100 \mathrm{~m}$ and a decrease to almost half the surface concentrations between 92 and $560 \mathrm{~m}$ (Figure 24).

\section{Summary and future perspectives}

Long term measurements are central to the understanding of atmospheric composition and its impact on climate. Whilst the data sets obtained at CVAO are not yet sufficient to detect trends, we have presented information on inter- and intraannual and diurnal cycles of surface trace gases and aerosol, with air mass trajectories and influences characterised by the NAME dispersion model. These show a strong influence from Saharan dust in winter, a year-round presence of ocean-derived organic and inorganic components in gaseous and particulate form which have impacts on aerosol formation and oxidation chemistry, and long range transport of $\mathrm{O}_{3}$ precursors from North America and Europe especially in spring/summer.

Saharan dust and sea salt dominate the super-micron aerosol particles at Cape Verde. Iron constituted a few $\%$ of the total aerosol mass of the super-micron dust, with aluminium, a tracer of mineral dust, at slightly higher concentrations. Both metals show highest concentrations in the winter months. The NAME model captured all of the dust events, showing that it correctly identifies the origin and pathways of air masses arriving at the CVAO, although it cannot be used to predict the intensity of a certain event. The COSMO-MUSCAT dust model was evaluated with in situ aerosol measurements from the CVAO as well as remote sensing data and showed promising agreement, indicating that the model reproduces size resolved dust deposition fluxes realistically. The model shows that in the Cape Verde region, dry deposition dominates the deposition of dust during most of the year. Saharan dust transport in the winter months occurs in the boundary layer below $2 \mathrm{~km}$ height and often extends down to the surface, which enhances the dry deposition flux. Whether dust is removed from the atmosphere as dry particles or washed out by rain can influence the chemical properties of the dust particles that are deposited into the ocean surface. Dissolution experiments on collected dust samples resulted in the release of between 0.1 and $14.3 \%$ of the total $\mathrm{Al}$ and between 0.1 and $15.7 \%$ of the total $\mathrm{Fe}$, with a strong correlation between soluble $\mathrm{Fe}$ and $\mathrm{Al}$ and much lower solubility measured at high atmospheric dust concentrations. The higher ratio of soluble $\mathrm{Fe}$ to $\mathrm{Al}$ compared to the total composition suggests that the soluble fraction is dominated by minerals containing higher amounts of Fe relative to $\mathrm{Al}$ than in the bulk material, e.g. phosphate.

The ionic composition of the aerosol at Cape Verde is dominated by sea salt but in particles below $<0.14 \mu \mathrm{m}$ diameter, non-sea salt components contributed about $80 \%$ of the mass. These components include low-molecular-weight dicarboxylic acids (DCAs) and hydroxylated DCAs, methanesulfonic acid (MSA) and aliphatic amines. A bimodal size distribution for the DCA oxalic acid and coarse mode concentration maxima for the other DCAs were observed, as is 
typical for marine aerosols. The MSA concentration closely followed that of non-sea-salt-sulfate and the size distribution showed a maximum mean concentration in accumulation mode and in sea salt particles. Aliphatic amines, assumed to be important in the growing process of sulfuric acid clusters, were correlated with phytoplankton activity in the subtropical North Atlantic, especially during an unexpected winter algal bloom.

Levels of ozone, CO and anthropogenic VOCs, including ethane and propane, show spring maxima and summer minima, in line with previous northern hemisphere observations, and were generally higher in the North American influenced air masses. In contrast, the OVOCs acetone and methanol showed a broad summer maximum, highest in the AFR/EUR sector, and with evidence of a coastal/upwelling source. $\mathrm{O}_{3} / \mathrm{CO}$ ratios were between $0.3-0.45$, highest in European air masses that contain relatively less well aged air with less opportunity for $\mathrm{O}_{3}$ photochemical destruction. In air heavily influenced by Saharan dust, the $\mathrm{O}_{3} / \mathrm{CO}$ ratio was as low as 0.13 , although with a significant positive offset in $\mathrm{O}_{3}$. The opposing effects of $\mathrm{O}_{3}$ uptake to dust and increased photochemical production of $\mathrm{O}_{3}$ during ageing due to higher $\mathrm{NO}_{\mathrm{x}}$ levels in African air make interpretation of these data difficult. $\mathrm{NO}_{\mathrm{x}}$ and $\mathrm{NO}_{\mathrm{y}}$ were most abundant in the African and European air masses and showed generally higher concentrations in winter when air mass origins are predominantly from Africa. This likely reflects biomass burning and soil emissions from the Sahel and local production of $\mathrm{NO}_{\mathrm{x}}$ from transported reservoir species (e.g. $\mathrm{HNO}_{3}$ and $\mathrm{PAN}$ ), with possible contributions from west African coastal cities and higher ship emissions from the northeast to easterly sectors. A more complete analysis of influences and impacts of nitrogen oxides at Cape Verde will be the subject of a future publication.

High photochemical activity is evident at this tropical location, with maximum concentrations of $\mathrm{OH}$ and $\mathrm{HO}_{2}$ of $9 \times 10^{6}$ molecule $\mathrm{cm}^{-3}$ and $6 \times 10^{8}$ molecule $\mathrm{cm}^{-3}$, respectively. The maximum contributions of $\mathrm{HO}_{2}$ (as measured by FAGE) to the hourly-averaged daytime budget of total peroxy radicals (as measured by PERCA) were 35-45\%, rather higher than previously measured ratios in low $\mathrm{NO}_{\mathrm{x}}$ conditions (Fleming et al., 2006; Hosaynali Beygi et al., 2011) presumably due to low VOC/CO ratios in the very clean air at Cape Verde. Model simulations of $\mathrm{HO}_{\mathrm{x}}$ could reproduce observations to within uncertainties if $\mathrm{HO}_{\mathrm{x}}$ aerosol uptake and the chemistry of $\mathrm{IO}$ and $\mathrm{BrO}$ were considered, and were most sensitive to changes in the aerosol parameters and to the concentrations of $\mathrm{BrO}$, IO and HCHO. Typical HCHO mixing ratios ranged between 350-550 pptv and, as expected from their dominant source from methane and NMHC, did not show strong inter-annual variation. Little diurnal variation in $\mathrm{HCHO}$ mixing ratios is observed because the sources (mainly hydrocarbon oxidation) and sinks (mainly photolysis and $\mathrm{OH}$ oxidation) are predominant during daytime and balance each other in this clean background environment.

$\mathrm{IO}$ and $\mathrm{BrO}$ were ubiquitously observed by the UOL LP-DOAS during the day at Cape Verde with maximum daytime mixing ratios of $\sim 1.5$ pptv IO and $\sim 2.5$ pptv BrO during the period November 2006 - June 2007. UOH MAX-DOAS observations indicated similar levels of IO ( $1.5 \mathrm{pptv}$, albeit with substantial uncertainties due to retrieval assumptions) in a thin layer of $100 \mathrm{~m}$ up to $500 \mathrm{~m}$. Model simulations indicate a strong vertical gradient in the IO mixing ratios, consistent with these observations. However, the UOH IO LP-DOAS and CE-DOAS observations show substantially different results for IO, with no observations above the detection limits of these instruments of 0.5 and 2.0 pptv, respectively. The differences between the IO concentrations during the period 2006-2007 and 2010 indicates either decreasing IO concentrations after 2007 or possible measurement interferences (e.g. stray light) for IO with the DOAS method. UOH LP-DOAS data from June-October 2010 showed BrO average daytime mixing ratios of 23.0 pptv, similar to the UOL LP-DOAS measurements (Read et al., 2008). Maximum values in the morning and evening, a local 
minimum at noon, and a strong variability from day to day with peak mixing ratios up to 6 pptv were observed. The $\mathrm{BrO}$ observations do not show a strong vertical gradient, indicating that it is well mixed in the boundary layer. Detailed 1-D modelling indicates that the $\mathrm{IO}$ and $\mathrm{BrO}$ account for up to $45 \%$ of the observed $\mathrm{O}_{3}$ destruction at the surface around Cape Verde.

The retrieval of aerosol extinction profiles from MAX-DOAS $\mathrm{O}_{4}$ measurements is a relatively new technique, and has so far only been applied to CVAO data for some selected days. A comprehensive analysis of the MAX-DOAS measurements planned for the near future will provide aerosol extinction profile data which is not only useful for the improvement of the accuracy of the MAX-DOAS trace gas retrieval, but also valuable for the investigation of the aerosol vertical distribution during Saharan dust events and their impact on the atmospheric radiation budget.

Finally, radiosonde and ceilometer data shows a strong amount of variability in inversion height over timescales of days, varying from 300 to $1500 \mathrm{~m}$. Thus, simple box models which assume invariant boundary layer heights are unlikely to simulate chemical variability accurately. No overall seasonal or diurnal pattern was evident in boundary layer heights, indicating no systematic difference between day-time and night-time entrainment rates.

Future studies at the Cape Verde Atmospheric Observatory Humberto Duarte Fonseca (CVAO) aim to build on the data presented herein, for example by elucidating the nature and magnitude of oceanic iodine emissions, quantifying the nitrogen oxides budget, evaluating the influence of dust on the ocean heat budget, and understanding oceanic nitrogen fixation.

\section{Acknowledgements}

We would like to thank all the scientists involved in measurements at the Cape Verde Atmospheric Observatory (CVAO) and during the RHaMBLe campaign in 2007 and the SOS campaigns in 2009. We would like to thank NOAA for the ESRL radiosonde data from the island of Sal. We would like to thank R. Leppert, R. Schwalbe and T. Seifert (MPI-BGC) for technical support for the greenhouse gas measurement equipment. We would like to acknowledge Pete Edwards and Andy Goddard from the University of Leeds for their technical support throughout the campaign and the UK Meteorological Office for the use of the Unified Meteorological data and the NAME model. We acknowledge funding from the NERC SOLAS program, the National Centre for Atmospheric Science (NCAS), the EU Specific Support Action TENATSO, and the SOPRAN project of the German Federal Ministry of Education and Research. 


\section{References}

Albrecht, B.A., Penc, R.S. and Schubert, W.H., 1985: An observational study of cloud-topped mixed layers. Journal of the Atmospheric Sciences, 42(8), 800-822.

Baker, A.R. and Croot, P.L., 2010: Atmospheric and marine controls on aerosol iron solubility in seawater. Marine Chemistry, 120(1-4), 4-13.

Barsanti, K.C., McMurry, P.H. and Smith, J.N., 2009: The potential contribution of organic salts to new particle growth. Atmospheric Chemistry and Physics, 9(9), 2949-2957.

Bauer, S.E., Balkanski, Y., Schulz, M., Hauglustaine, D.A. and Dentener, F., 2004: Global modeling of heterogeneous chemistry on mineral aerosol surfaces: Influence on tropospheric ozone chemistry and comparison to observations. Journal of Geophysical Research, 109(D2).

Bechara, J., Borbon, A., Jambert, C., Colomb, A. and Perros, P.E., 2010: Evidence of the impact of deep convection on reactive Volatile Organic Compounds in the upper tropical troposphere during the AMMA experiment in West Africa. Atmospheric Chemistry and Physics, 10(21), 10321-10334.

Behrenfeld, M.J., O'Malley, R.T., Siegel, D.A., McClain, C.R., Sarmiento, J.L., Feldman, G.C., Milligan, A.J., Falkowski, P.G., Letelier, R.M. and Boss, E.S., 2006: Climate-driven trends in contemporary ocean productivity. Nature, 444(7120), 752-755.

Betts, A.K., Bretherton, C.S. and Klinker, E., 1995: Relation between mean boundary-layer structure and cloudiness at the R/V Valdivia during ASTEX. Journal of the Atmospheric Sciences, 52(16), 27522762.

Bian, H.S. and Zender, C.S., 2003: Mineral dust and global tropospheric chemistry: Relative roles of photolysis and heterogeneous uptake. Journal of Geophysical Research, 108(D21).

Blaine, T.W., Keeling, R.F. and Paplawsky, W.J., 2006: An improved inlet for precisely measuring the atmospheric Ar/ $\mathrm{N}_{2}$ ratio. Atmospheric Chemistry and Physics, 6, 1181-1184.

Bloss, W.J., Evans, M.J., Lee, J.D., Sommariva, R., Heard, D.E. and Pilling, M.J., 2005: The oxidative capacity of the troposphere: Coupling of field measurements of $\mathrm{OH}$ and a global chemistry transport model. Faraday Discussions, 130, 425-436.

Bridgeman, C.H., Pyle, J.A. and Shallcross, D.E., 2000: A three-dimensional model calculation of the ozone depletion potential of 1-bromopropane (1-C3H7Br). Journal of Geophysical Research-Atmospheres, 105(D21), 26493-26502.

Buck, C.S., Landing, W.M., Resing, J.A. and Lebon, G.T., 2006: Aerosol iron and aluminum solubility in the northwest Pacific Ocean: Results from the 2002 IOC cruise. Geochemistry Geophysics Geosystems, 7(Q04M07).

Chiapello, I. and Moulin, C., 2002: TOMS and METEOSAT satellite records of the variability of Saharan dust transport over the Atlantic during the last two decades (1979-1997). Geophysical Research Letters, 29(8), 4.

Commane, R., Floquet, C.F.A., Ingham, T., Stone, D., Evans, M.J. and Heard, D.E., 2010: Observations of $\mathrm{OH}$ and HO2 radicals over West Africa. Atmospheric Chemistry and Physics, 10(18), 8783-8801.

DeCarlo, P., Slowik, J., Worsnop, D.R. and Davidovits, P.J.J., 2004: Particle morphology and density characterization by combined mobility and aerodynamic diameter measurements. part 1: Theory. . Aerosol Sci. Technol., 38, 1185 - 1205.

Dentener, F.J., Carmichael, G.R., Zhang, Y., Lelieveld, J. and Crutzen, P.J., 1996: Role of mineral aerosol as a reactive surface in the global atmosphere. J. Geophys. Res., 101, 22869-22890.

Deutschmann, T., Beierle, S., Frieß, U., Grzegorski, M., Kern, C., Kritten, L., Pfeilsticker, K., Platt, U., Prados-Roman, C., Pukite, J., Wagner, T. and Werner, B., 2011: The Monte Carlo atmospheric radiative tranfer model McArtim: Intruduction and validation of Jacobians and 3D features. Journal of Quantitative Spectroscopy and Radiative Transfer, 112, 1119-1137.

Evan, A.T., Vimont, D.J., Heidinger, A.K., Kossin, J.P. and Bennartz, R., 2009: The Role of Aerosols in the Evolution of Tropical North Atlantic Ocean Temperature Anomalies. Science, 324(5928), 778-781.

Facchini, M.C., Rinaldi, M., Decesari, S., Carbone, C., Finessi, E., Mircea, M., Fuzzi, S., Ceburnis, D., Flanagan, R., Nilsson, E.D., de Leeuw, G., Martino, M., Woeltjen, J. and O'Dowd, C.D., 2008: Primary submicron marine aerosol dominated by insoluble organic colloids and aggregates. Geophysical Research Letters, 35(17), 5. 
Farmer, D.K., Wooldridge, P.J. and Cohen, R.C., 2006: Application of thermal-dissociation laser induced fluorescence (TD-LIF) to measurement of HNO3, \&Sigma;alkyl nitrates, \&Sigma;peroxy nitrates, and NO2 fluxes using eddy covariance. Atmospheric Chemistry \& Physics, 6(11), 3471-3486.

Fenter, F.F., Caloz, F. and Rossi, M.J., 1995: Experimental-evidence for the efficient dry deposition of nitricacid on calcite. Atmospheric Environment, 29(22), 3365-3372.

Fleming, Z.L., Monks, P.S., Rickard, A.R., Heard, D.E., Bloss, W.J., Seakins, P.W., Still, T.J., Sommariva, R., Pilling, M.J., Morgan, R., Green, T.J., Brough, N., Mills, G.P., Penkett, S.A., Lewis, A.C., Lee, J.D., Saiz-Lopez, A. and Plane, J.M.C., 2006: Peroxy radical chemistry and the control of ozone photochemistry at Mace Head, Ireland during the summer of 2002. Atmospheric Chemistry and Physics, 6, 2193-2214.

Foltz, G.R. and McPhaden, M.J., 2008: Impact of Saharan dust on tropical North Atlantic SST. Journal of Climate, 21(19), 5048-5060.

Forster, P., V. Ramaswamy, P. Artaxo, T. Berntsen, R. Betts, D.W. Fahey, J. Haywood, J. Lean, D.C. Lowe, G. Myhre, J. Nganga, R. Prinn, G. Raga, M. Schulz and R. Van Dorland, 2007: Changes in Atmospheric Constituents and in Radiative Forcing. In: Climate Change 2007: The Physical Science Basis. Contribution of Working Group I to the Fourth Assessment Report of the Intergovernmental Panel on Climate Change, Solomon, S., D. Qin, M. Manning, Z. Chen, M. Marquis, K.B. Averyt, M.Tignor and H.L. Miller (eds.). Cambridge University Press, Cambridge, United Kingdom.

Gros, V., Williams, J., Lawrence, M.G., von Kuhlmann, R., van Aardenne, J., Atlas, E., Chuck, A., Edwards, D.P., Stroud, V. and Krol, M., 2004: Tracing the origin and ages of interlaced atmospheric pollution events over the tropical Atlantic Ocean with in situ measurements, satellites, trajectories, emission inventories, and global models. Journal of Geophysical Research, 109(D22).

Hagen, E., 2001: Northwest African upwelling scenario. Oceanologica Acta, 24, S113-S128.

Hanisch, F. and Crowley, J.N., 2001: Heterogeneous reactivity of gaseous nitric acid on Al2O3, CaCO3, and atmospheric dust samples: A Knudsen cell study. Journal of Physical Chemistry A, 105(13), 30963106.

Hanisch, F. and Crowley, J.N., 2003: Heterogeneous reactivity of NO and HNO3 on mineral dust in the presence of ozone. Physical Chemistry Chemical Physics, 5(5), 883-887.

Hanson, H.P., 1991: Marine stratocumulus climatologies. International Journal of Climatology, 11(2), 147164.

Hao, W.M., Ward, D.E., Olbu, G. and Baker, S.P., 1996: Emissions of CO2, CO, and hydrocarbons from fires in diverse African savanna ecosystems. Journal of Geophysical Research, 101(D19), 2357723584.

Heard, D.E. and Pilling, M.J., 2003: Measurement of $\mathrm{OH}$ and $\mathrm{HO}_{2}$ in the Troposphere. Chemical Reviews, 103, 5163-5198.

Heinold, B., Helmert, J., Hellmuth, O., Wolke, R., Ansmann, A., Marticorena, B., Laurent, B. and Tegen, I., 2007: Regional modeling of Saharan dust events using LM-MUSCAT: Model description and case studies. Journal of Geophysical Research, 112(D11).

Helmig, D., Bottenheim, J., Galbally, I.E., Lewis, A., Milton, M.J.T., Penkett, S., Plass-Duelmer, C., Reimann, S., Tans, P. and Theil, S., 2009: Volatile Organic Compounds in the Global Atmosphere. Eos Trans. AGU, 90(52).

Hewitt, C.N., Lee, J.D., MacKenzie, A.R., Barkley, M.P., Carslaw, N., Carver, G.D., Chappell, N.A., Coe, H., Collier, C., Commane, R., Davies, F., Davison, B., Di Carlo, P., Di Marco, C.F., Dorsey, J.R., Edwards, P.M., Evans, M.J., Fowler, D., Furneaux, K.L., Gallagher, M., Guenther, A., Heard, D.E., Helfter, C., Hopkins, J., Ingham, T., Irwin, M., Jones, C., Karunaharan, A., Langford, B., Lewis, A.C., Lim, S.F., MacDonald, S.M., Mahajan, A.S., Malpass, S., McFiggans, G., Mills, G., Misztal, P., Moller, S., Monks, P.S., Nemitz, E., Nicolas-Perea, V., Oetjen, H., Oram, D.E., Palmer, P.I., Phillips, G.J., Pike, R., Plane, J.M.C., Pugh, T., Pyle, J.A., Reeves, C.E., Robinson, N.H., Stewart, D., Stone, D., Whalley, L.K. and Yin, X., 2010: Overview: oxidant and particle photochemical processes above a south-east Asian tropical rainforest (the OP3 project): introduction, rationale, location characteristics and tools. Atmospheric Chemistry and Physics, 10(1), 169-199.

Holloway, J.S., Jakoubek, R.O., Parrish, D.D., Gerbig, C., Volz-Thomas, A., Schmitgen, S., Fried, A., Wert, B., Henry, B. and Drummond, J.R., 2000: Airborne intercomparison of vacuum ultraviolet fluorescence and tunable diode laser absorption measurements of tropospheric carbon monoxide. Journal of Geophysical Research-Atmospheres, 105(D19), 24251-24261. 
Hopkins, J.R., Lewis, A.C. and Read, K.A., 2003: A two-column method for long-term monitoring of nonmethane hydrocarbons (NMHCs) and oxygenated volatile organic compounds (o-VOCs). Journal of Environmental Monitoring, 5(1), 8-13.

Horowitz, L.W., Walters, S., Mauzerall, D.L., Emmons, L.K., Rasch, P.J., Granier, C., Tie, X.X., Lamarque, J.F., Schultz, M.G., Tyndall, G.S., Orlando, J.J. and Brasseur, G.P., 2003: A global simulation of tropospheric ozone and related tracers: Description and evaluation of MOZART, version 2. Journal of Geophysical Research, 108(D24).

Hosaynali Beygi, Z., Fischer, H., Harder, H.D., Martinez, M., Sander, R., Williams, J., Brookes, D.M., Monks, P.S. and Lelieveld, J., 2011: Oxidation photochemistry in the Southern Atlantic boundary layer: unexpected deviations of photochemical steady state. Atmos. Chem. Phys. Discuss., 11(3), 7045-7093.

Ingham, T., Goddard, A., Whalley, L.K., Furneaux, K.L., Edwards, P.M., Seal, C.P., Self, D.E., Johnson, G.P., Read, K.A., Lee, J.D. and Heard, D.E., 2009: A flow-tube based laser-induced fluorescence instrument to measure $\mathrm{OH}$ reactivity in the troposphere. Atmospheric Measurement Techniques, 2(2), 465-477.

Jacobi, H.W., Weller, R., Bluszcz, T. and Schrems, O., 1999: Latitudinal distribution of peroxyacetyl nitrate (PAN) over the Atlantic Ocean. Journal of Geophysical Research-Atmospheres, 104(D21), 2690126912.

Jones, C.E., Hornsby, K.E., Sommariva, R., Dunk, R.M., Von Glasow, R., McFiggans, G. and Carpenter, L.J., 2010: Quantifying the contribution of marine organic gases to atmospheric iodine. Geophysical Research Letters, 37, DOI 10.1029/2010gl043990.

Kaufman, Y.J., Koren, I., Remer, L.A., Tanre, D., Ginoux, P. and Fan, S., 2005: Dust transport and deposition observed from the Terra-Moderate Resolution Imaging Spectroradiometer ( MODIS) spacecraft over the Atlantic ocean. Journal of Geophysical Research, 110(D10).

Kock, A., Gebhardt, S. and Bange, H.W., 2008: Methane emissions from the upwelling area off Mauritania (NW Africa). Biogeosciences, 5(4), 1119-1125.

Kozlova, E.A. and Manning, A.C., 2009: Methodology and calibration for continuous measurements of biogeochemical trace gas and $\mathrm{O}_{2}$ concentrations from a $300-\mathrm{m}$ tall tower in central Siberia. Atmospheric Measurement Techniques, 2(1), 205-220.

Kurten, T., Loukonen, V., Vehkamaki, H. and Kulmala, M., 2008: Amines are likely to enhance neutral and ion-induced sulfuric acid-water nucleation in the atmosphere more effectively than ammonia. Atmospheric Chemistry and Physics, 8(14), 4095-4103.

Lawler, M.J., Finley, B.D., Keene, W.C., Pszenny, A.A.P., Read, K.A., von Glasow, R. and Saltzman, E.S., 2009: Pollution-enhanced reactive chlorine chemistry in the eastern tropical Atlantic boundary layer. Geophysical Research Letters, 36, DOI 10.1029/2008GL036666.

Lawrence, M.G., Jöckel, P. and von Kuhlmann, R., 2001: What does the global mean OH concentration tell us? Atmospheric Chemistry \& Physics, 1(1), 37-49.

Lee, J.D., McFiggans, G., Allan, J.D., Baker, A.R., Ball, S.M., Benton, A.K., Carpenter, L.J., Commane, R., Finley, B.D., Evans, M., Fuentes, E., Furneaux, K., Goddard, A., Good, N., Hamilton, J.F., Heard, D.E., Herrmann, H., Hollingsworth, A., Hopkins, J.R., Ingham, T., Irwin, M., Jones, C.E., Jones, R.L., Keene, W.C., Lawler, M.J., Lehmann, S., Lewis, A.C., Long, M.S., Mahajan, A., Methven, J., Moller, S.J., Muller, K., Muller, T., Niedermeier, N., O'Doherty, S., Oetjen, H., Plane, J.M.C., Pszenny, A.A.P., Read, K.A., Saiz-Lopez, A., Saltzman, E.S., Sander, R., von Glasow, R., Whalley, L., Wiedensohler, A. and Young, D., 2010: Reactive Halogens in the Marine Boundary Layer (RHaMBLe): the tropical North Atlantic experiments. Atmospheric Chemistry and Physics, 10(3), 1031-1055.

Lee, J.D., Moller, S.J., Read, K.A., Lewis, A.C., Mendes, L. and Carpenter, L.J., 2009: Year-round measurements of nitrogen oxides and ozone in the tropical North Atlantic marine boundary layer. Journal of Geophysical Research, 114, DOI 10.1029/2009jd011878.

Lewis, A.C., Evans, M.J., Methven, J., Watson, N., Lee, J.D., Hopkins, J.R., Purvis, R.M., Arnold, S.R., McQuaid, J.B., Whalley, L.K., Pilling, M.J., Heard, D.E., Monks, P.S., Parker, A.E., Reeves, C.E., Oram, D.E., Mills, G., Bandy, B.J., Stewart, D., Coe, H., Williams, P. and Crosier, J., 2007: Chemical composition observed over the mid-Atlantic and the detection of pollution signatures far from source regions. Journal of Geophysical Research, 112(D10). 
Liao, H. and Seinfeld, J.H., 2005: Global impacts of gas-phase chemistry-aerosol interactions on direct radiative forcing by anthropogenic aerosols and ozone. J. Geophys. Res., 110. 18208.

Lilly, D.K., 1968: Models of cloud-topped mixed layers under a strong inversion. Q. J. Roy. Meteor. Soc., 94, 292-309.

Loukonen, V., Kurten, T., Ortega, I.K., Vehkamaki, H., Padua, A.A.H., Sellegri, K. and Kulmala, M., 2010: Enhancing effect of dimethylamine in sulfuric acid nucleation in the presence of water - a computational study. Atmospheric Chemistry and Physics, 10(10), 4961-4974.

Mace, A.R., Wang, W., Fleming, Z.L., Carpenter, L.J., Lee, J.D., Read, K.A., Lewis, A.C., von Glasow, R. and Sommariva, R., 2011: Cluster Analysis of the Origin and Transport of Atmospheric Chemical Species. Journal of Atmospheric Chemistry (submitted).

Mahajan, A.S., Plane, J.M.C., Oetjen, H., Mendes, L., Saunders, R.W., Saiz-Lopez, A., Jones, C.E., Carpenter, L.J. and McFiggans, G.B., 2010: Measurement and modelling of tropospheric reactive halogen species over the tropical Atlantic Ocean. Atmospheric Chemistry and Physics, 10(10), 46114624.

Mahajan, A.S., Whalley, L. K., Kozlova, E., Oetjen, H., Mendes, L., Furneaux, K. L., Goddard, A., Heard, D. E., Plane, J. M. and Saiz-Lopez, A., 2011 submitted: DOAS observations of formaldehyde and its impact on the HOx balance in the tropical Atlantic marine boundary layer. Atmospheric Environment.

Mahowald, N.M., Baker, A.R., Bergametti, G., Brooks, N., Duce, R.A., Jickells, T.D., Kubilay, N., Prospero, J.M. and Tegen, I., 2005: Atmospheric global dust cycle and iron inputs to the ocean. Global Biogeochemical Cycles, 19(4).

Makela, J.M., Yli-Koivisto, S., Hiltunen, V., Seidl, W., Swietlicki, E., Teinila, K., Sillanpaa, M., Koponen, I.K., Paatero, J., Rosman, K. and Hameri, K., 2001: Chemical composition of aerosol during particle formation events in boreal forest. Tellus Series B-Chemical and Physical Meteorology, 53(4), 380393.

Manning, A.C. and Keeling, R.F., 2006: Global oceanic and land biotic carbon sinks from the Scripps atmospheric oxygen flask sampling network. Tellus Series B-Chemical and Physical Meteorology, 58(2), 95-116.

Martínez Avellaneda, N., Serra, N., Minnett, P.J. and Stammer, D., 2010: Response of the eastern subtropical Atlantic SST to Saharan dust: A modeling and observational study. J. Geophys. Res., 115(C8), C08015.

Measures, C.I. and Vink, S., 2000: On the use of dissolved aluminum in surface waters to estimate dust deposition to the ocean. Global Biogeochem. Cycles, 14(1), 317-327.

Merten, A., Tschritter, J. and Platt, U., 2011: Design of differential optical absorption spectroscopy long-path telescopes based on fiber optics. Applied Optics, 50(5), 738-754.

Mills, M.M., Ridame, C., Davey, M., La Roche, J. and Geider, R.J., 2004: Iron and phosphorus co-limit nitrogen fixation in the eastern tropical North Atlantic. Nature, 429(6989), 292-294.

Monks, P.S., 2005: Gas-phase radical chemistry in the troposphere. Chemical Society Reviews, 34(5), 376395.

Monks, P.S., Carpenter, L.J., Penkett, S.A. and Ayers, G.P., 1996: Night-time peroxy radical chemistry in the remote marine boundary layer over the Southern ocean. Geophysical Research Letters, 23(5), 535-538.

Monks, P.S., Salisbury, G., Holland, G., Penkett, S.A. and Ayers, G.P., 2000: A seasonal comparison of ozone photochemistry in the remote marine boundary layer. Atmospheric Environment, 34(16), 2547-2561.

Moore, C.M., Mills, M.M., Achterberg, E.P., Geider, R.J., LaRoche, J., Lucas, M.I., McDonagh, E.L., Pan, X., Poulton, A.J., Rijkenberg, M.J.A., Suggett, D.J., Ussher, S.J. and Woodward, E.M.S., 2009: Large-scale distribution of Atlantic nitrogen fixation controlled by iron availability. Nature Geoscience, 2(12), 867-871.

Moulin, C., Lambert, C.E., Dulac, F. and Dayan, U., 1997: Control of atmospheric export of dust from North Africa by the North Atlantic oscillation. Nature, 387(6634), 691-694.

Müller, C., Iinuma, Y., Karstensen, J., van Pinxteren, D., Lehmann, S., Gnauk, T. and Herrmann, H., 2009: Seasonal variation of aliphatic amines in marine sub-micrometer particles at the Cape Verde islands. Atmospheric Chemistry and Physics, 9(24), 9587-9597. 
Müller, K., Lehmann, S., van Pinxteren, D., Gnauk, T., Niedermeier, N., Wiedensohler, A. and Herrmann, H., 2010: Particle characterization at the Cape Verde atmospheric observatory during the 2007 RHaMBLe intensive. Atmospheric Chemistry and Physics, 10(6), 2709-2721.

Olivier, J., Bouwman, A., Maas, C. v. d., Berdowski, J., Veldt, C., Bloos, J., and Visschedijk, A., Zandveld, P., Haverlag, J., 1996: Description of EDGAR Version 2.0: A set of global emission inventories of greenhouse gases and ozone-depleting substances for all anthropogenic and most natural sources on a per country basis and on 1 degree x 1 degree grid. . Natl. Inst. of Public Health and the Environ., Bilthoven, Netherlands.

Parrish, D.D., Buhr, M.P., Trainer, M., Norton, R.B., Shimshock, J.P., Fehsenfeld, F.C., Anlauf, K.G., Bottenheim, J.W., Tang, Y.Z., Wiebe, H.A., Roberts, J.M., Tanner, R.L., Newman, L., Bowersox, V.C., Olszyna, K.J., Bailey, E.M., Rodgers, M.O., Wang, T., Berresheim, H., Roychowdhury, U.K. and Demerjian, K.L., 1993: The total recative nitrogen levels and the partititioning between the individual-species at 6 rural sites in eastern North America. Journal of Geophysical Research, 98(D2), 2927-2939.

Parrish, D.D., Trainer, M., Holloway, J.S., Yee, J.E., Warshawsky, M.S., Fehsenfeld, F.C., Forbes, G.L. and Moody, J.L., 1998: Relationships between ozone and carbon monoxide at surface sites in the North Atlantic region. Journal of Geophysical Research, 103(D11), 13357-13376.

Plane, J.M. and Saiz-Lopez, A.: Differential Optical Absorption Spectroscopy, in Analytical Techniques for Atmospheric Measurement. Blackwell, Oxford (2006)

Prospero, J.M. and Lamb, P.J., 2003: African droughts and dust transport to the Caribbean: Climate change implications. Science, 302, 1,024-021,027.

Read, K.A., Lee, J.D., Lewis, A.C., Moller, S.J., Mendes, L. and Carpenter, L.J., 2009: Intra-annual cycles of NMVOC in the tropical marine boundary layer and their use for interpreting seasonal variability in CO. Journal of Geophysical Research, 114, DOI 10.1029/2009jd011879.

Read, K.A., Mahajan, A.S., Carpenter, L.J., Evans, M.J., Faria, B.V.E., Heard, D.E., Hopkins, J.R., Lee, J.D., Moller, S.J., Lewis, A.C., Mendes, L., McQuaid, J.B., Oetjen, H., Saiz-Lopez, A., Pilling, M.J. and Plane, J.M.C., 2008: Extensive halogen-mediated ozone destruction over the tropical Atlantic Ocean. Nature, 453(7199), 1232-1235.

Real, E., Law, K.S., Schlager, H., Roiger, A., Huntrieser, H., Methven, J., Cain, M., Holloway, J., Neuman, J.A., Ryerson, T., Flocke, F., de Gouw, J., Atlas, E., Donnelly, S. and Parrish, D., 2008: Lagrangian analysis of low altitude anthropogenic plume processing across the North Atlantic. Atmospheric Chemistry and Physics, 8(24), 7737-7754.

Reeves, C.E. and Penkett, S.A., 2003: Measurements of peroxides and what they tell us. Chemical Reviews, 103(12), 5199-5218.

Richardson, A.J. and Schoeman, D.S., 2004: Climate impact on plankton ecosystems in the Northeast Atlantic. Science, 305(5690), 1609-1612.

Richter, A. and Burrows, J.P., 2002: Tropospheric NO2 from GOME measurements. Advances in Space Research, 29(11), 1673-1683.

Ryall, D.B., Derwent, R.G., Manning, A.J., Simmonds, P.G. and O'Doherty, S., 2001: Estimating source regions of European emissions of trace gases from observations at Mace Head. Atmospheric Environment, 35(14), 2507-2523.

Savoie, D.L., Prospero, J.M., Oltmans, S.J., Graustein, W.C., Turekian, K.K., Merrill, J.T. and Levy, H., 1992: Sources of nitrate and ozone in the marine boundary-layer of the tropical North-Atlantic. Journal of Geophysical Research, 97(D11), 11575-11589.

Schepanski, K., Tegen, I. and Macke, A., 2009: Saharan dust transport and deposition towards the tropical northern Atlantic. Atmospheric Chemistry and Physics, 9(4), 1173-1189.

Severinghaus, J.P.: Studies of the terrestrial $\mathrm{O}_{2}$ and carbon cycles in sand dune gases and in Biosphere 2. Ph.D., Columbia University (1995)

Simmonds, P.G. and Derwent, R.G., 1991: Measurements of ozone and other radiatively active gases at Mace Head in the Republic of Ireland. Atmospheric Environment, 25(9), 1795-1808.

Smith, J.N., Barsanti, K.C., Friedli, H.R., Ehn, M., Kulmala, M., Collins, D.R., Scheckman, J.H., Williams, B.J. and McMurry, P.H., 2010: Observations of aminium salts in atmospheric nanoparticles and possible climatic implications. Proceedings of the National Academy of Sciences of the United States of America, 107 (15), 6634-6639. 
Sokolik, I.N. and Toon, O.B., 1996: Direct radiative forcing by anthropogenic airborne mineral aerosols. Nature, 381(6584), 681-683.

Stephens, B.B., Keeling, R.F., Heimann, M., Six, K.D., Murnane, R. and Caldeira, K., 1998: Testing global ocean carbon cycle models using measurements of atmospheric $\mathrm{O}_{2}$ and $\mathrm{CO}_{2}$ concentration. Global Biogeochemical Cycles, 12(2), 213-230.

Stewart, D.J., Taylor, C.M., Reeves, C.E. and McQuaid, J.B., 2008: Biogenic nitrogen oxide emissions from soils: impact on NOx and ozone over west Africa during AMMA (African Monsoon Multidisciplinary Analysis): observational study. Atmospheric Chemistry \& Physics, 8(8), 22852297.

Stramma, L., Brandt, P., Schafstall, J., Schott, F., Fischer, J. and Kortzinger, A., 2008: Oxygen minimum zone in the North Atlantic south and east of the Cape Verde Islands. Journal of Geophysical Research, 113(C4), C04014-.

Stull, R.B.: An Introduction to Boundary Layer Meteorology. Kluwer Academic Publishers, Dordrecht, Boston, London (1988)

Tie, X.X., Madronich, S., Walters, S., Edwards, D.P., Ginoux, P., Mahowald, N., Zhang, R. Y., Lou, C. and Brasseur, G., 2005: Assessment of the global impact of aerosols on tropospheric oxidants. Journal of Geophysical Research, 110(D3).

Vaughan, S., Ingham, T., Whalley, L.K., Stone, D., Evans, M.J., Read, K.A., Lee, J.D., Carpenter, L.J. and Heard, D.E., 2011 in preparation: Seasonal observations of OH and HO2 in the remote tropical marine boundary layer

Wang, S.C. and Flagan, R.C., 1989: Scanning Electrical Mobility Spectrometer. J. Aerosol Sci., 20, 14851488.

Whalley, L.K., Furneaux, K.L., Goddard, A., Lee, J.D., Mahajan, A., Oetjen, H., Read, K.A., Kaaden, N., Carpenter, L.J., Lewis, A.C., Plane, J.M.C., Saltzman, E.S., Wiedensohler, A. and Heard, D.E., 2010: The chemistry of $\mathrm{OH}$ and $\mathrm{HO} 2$ radicals in the boundary layer over the tropical Atlantic Ocean. Atmospheric Chemistry and Physics, 10(4), 1555-1576.

Yienger, J.J. and Levy, H., 1995: Empirical-model of global soil-biogenic NOx emissions. Journal of Geophysical Research-Atmospheres, 100(D6), 11447-11464.

Zeng, X.B., Brunke, M.A., Zhou, M.Y., Fairall, C., Bond, N.A. and Lenschow, D.H., 2004: Marine atmospheric boundary layer height over the eastern Pacific: Data analysis and model evaluation. Journal of Climate, 17(21), 4159-4170. 


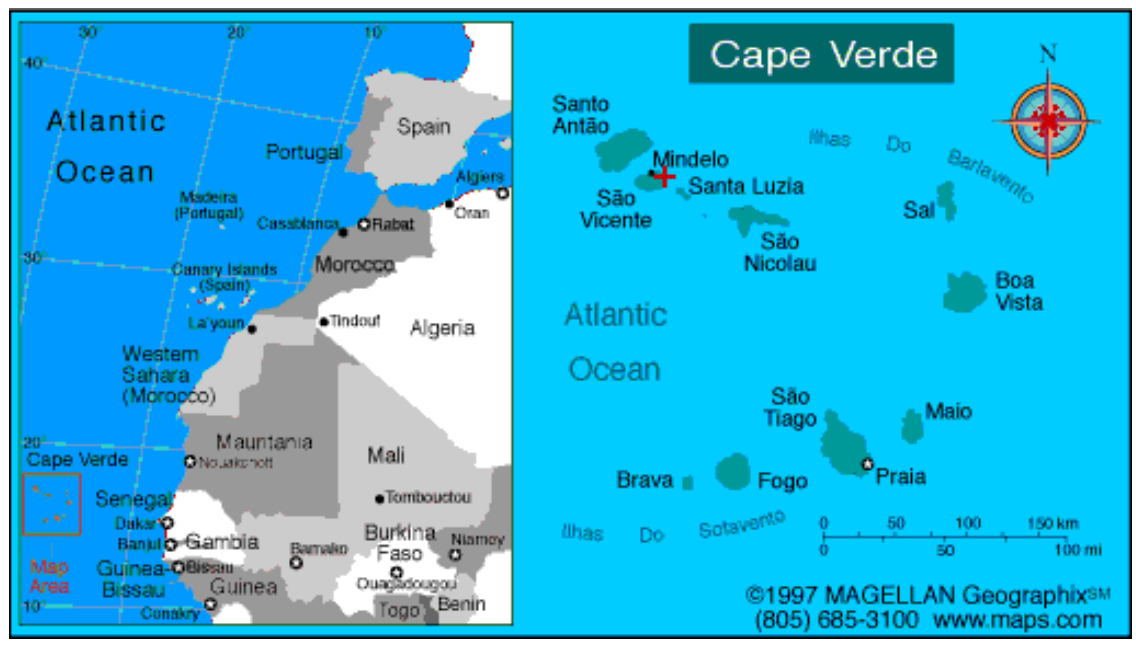

Figure 1. The Cape Verde Islands and location of the Observatory, marked on São Vicente with a red cross. Prevailing trade winds are from the north-east. 

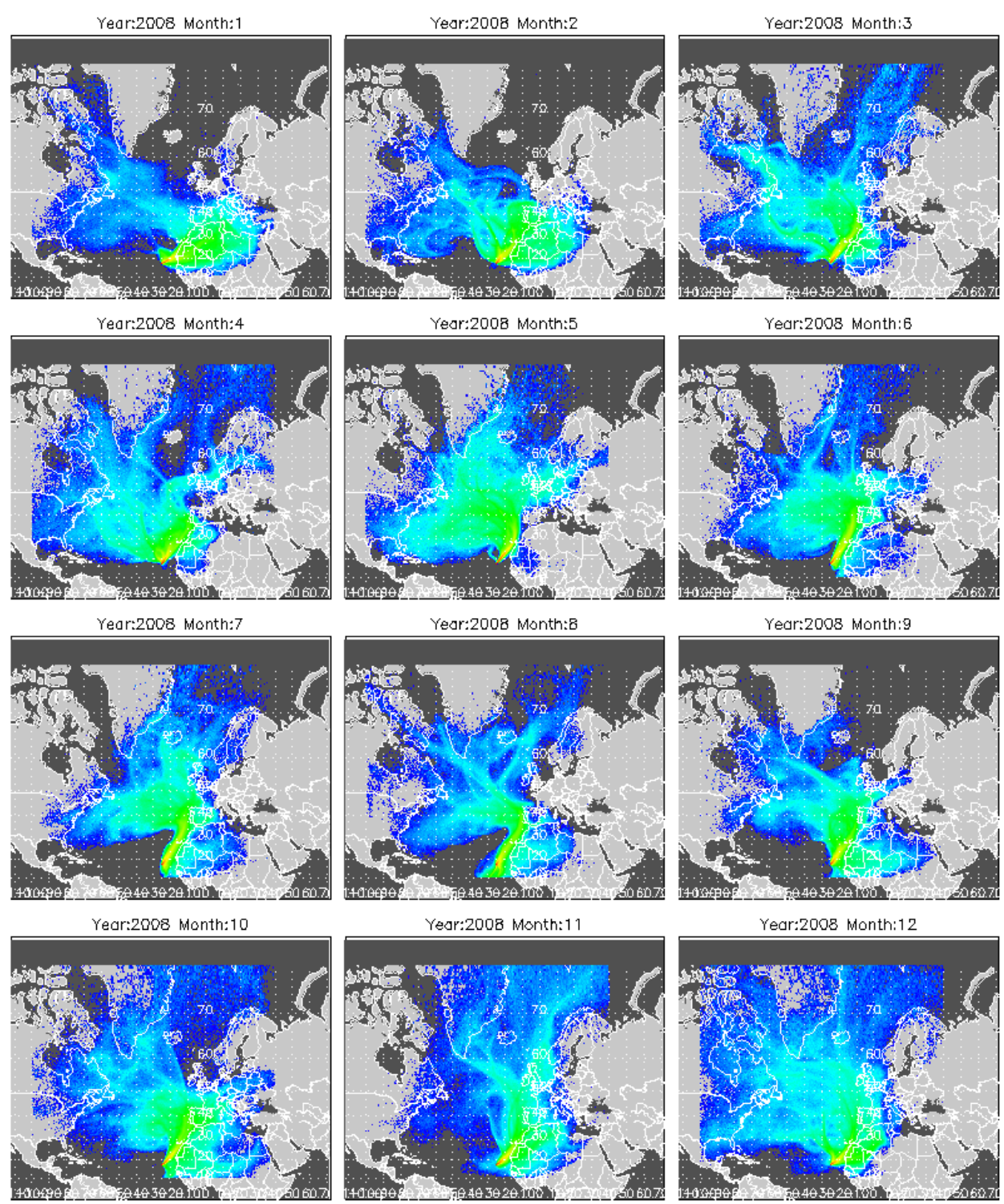

Figure 2. 2008 monthly integrated NAME footprints for CVAO, consisting of accumulated 3 hour releases for 10 days backwards.

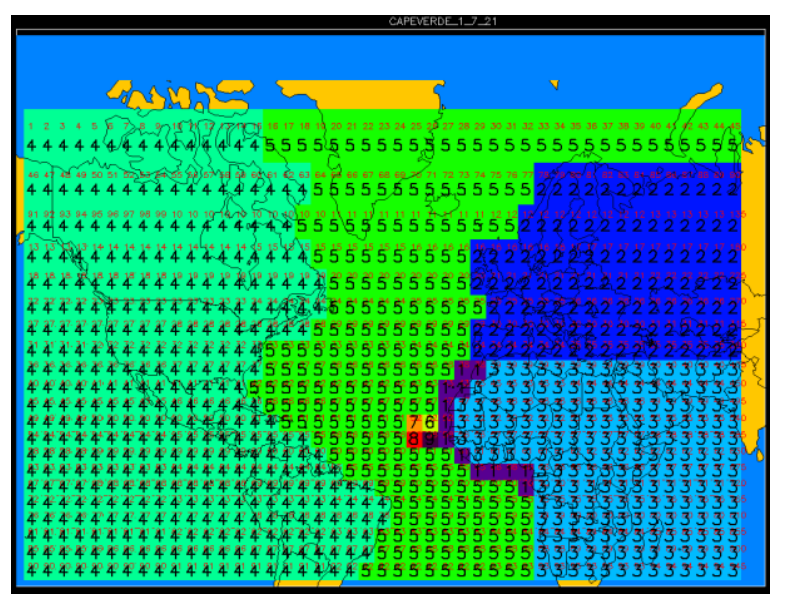

$1=$ Coastal African

$2=$ Polluted marine (Europe)

$3=$ Saharan Africa (Dust)

$4=$ Atlantic continental (US)

$5=$ Atlantic marine

Figure 3. Geographical sector divisions for classification of the land and marine footprints influencing Cape Verde. 


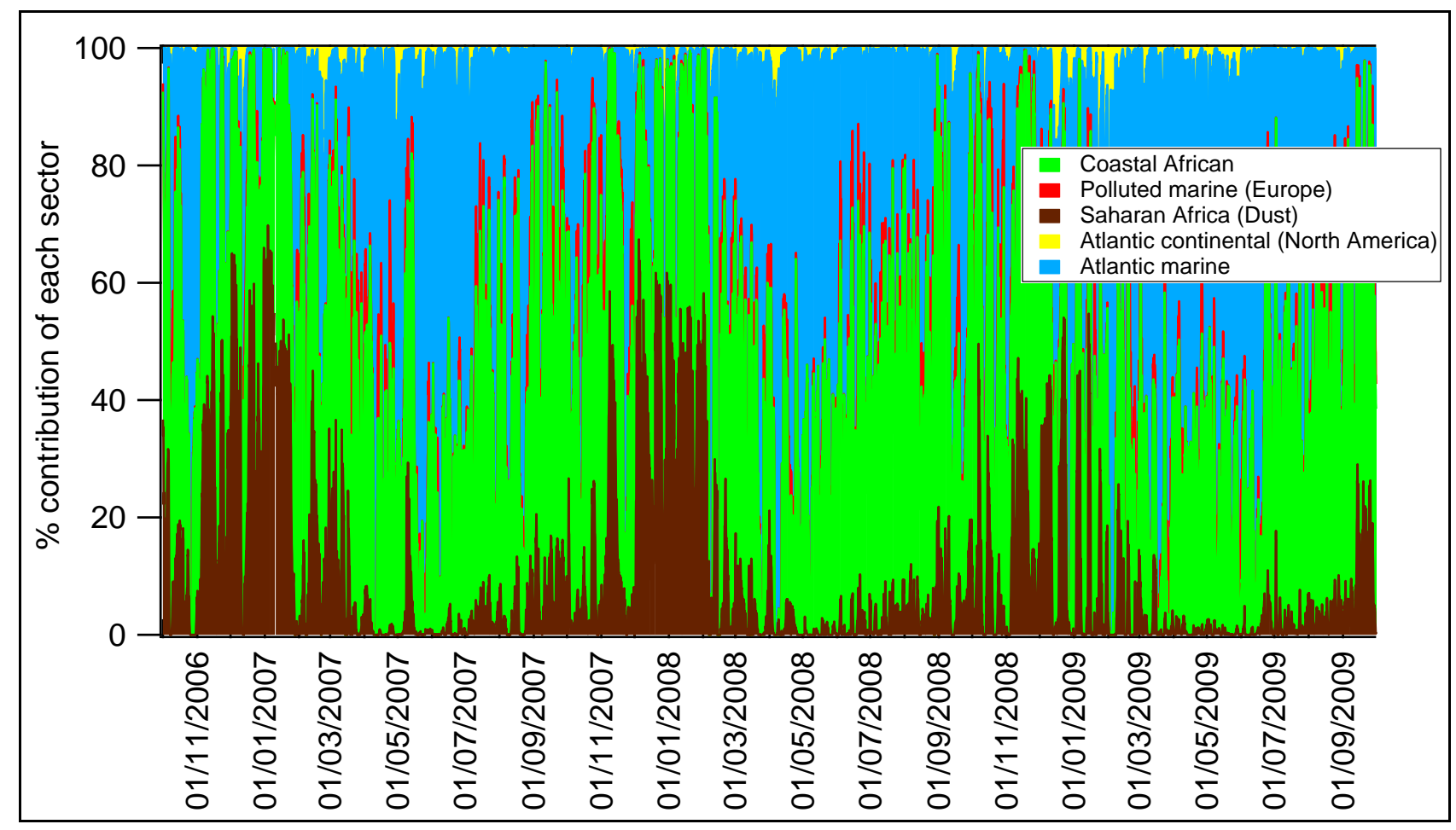

Figure 4. Percentage contribution of the 5 main sectors to the number of particles (inert tracers) arriving at the station between October 2006 and September 2009 during 10 day back trajectories, as calculated by the NAME dispersion model.
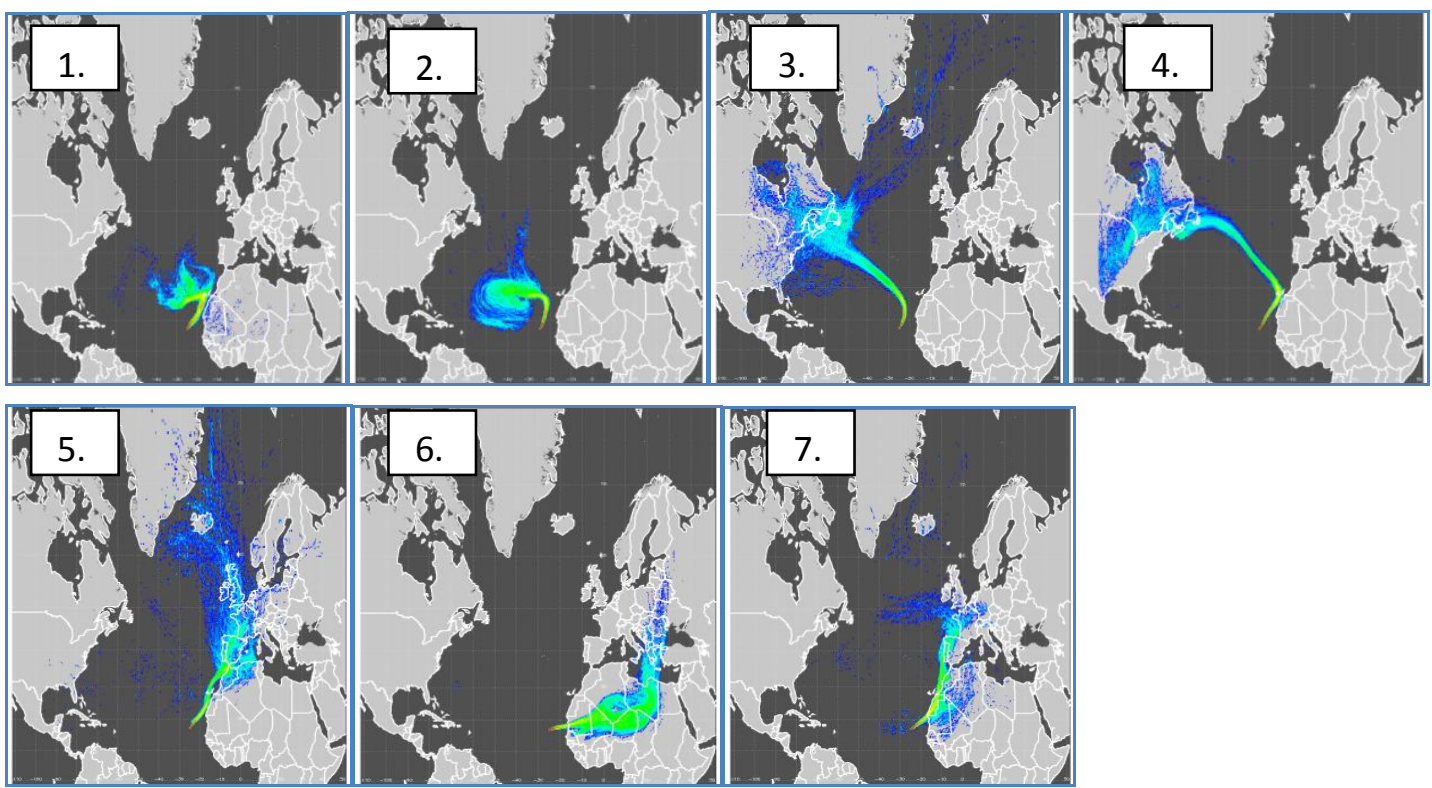

Figure 5. Typical 10-day dispersion footprints of the 7 main air mass trajectories arriving at Cape Verde. 1) Atlantic and African coastal - AAC, 2) Atlantic marine - AM, 3) North American and Atlantic - NAA, 4) North American and coastal African - NCA, 5) European (with minimal African influence) - EUR, 6) African (with minimal European influence) - AFR, 7) European and African - EUR/AFR. 

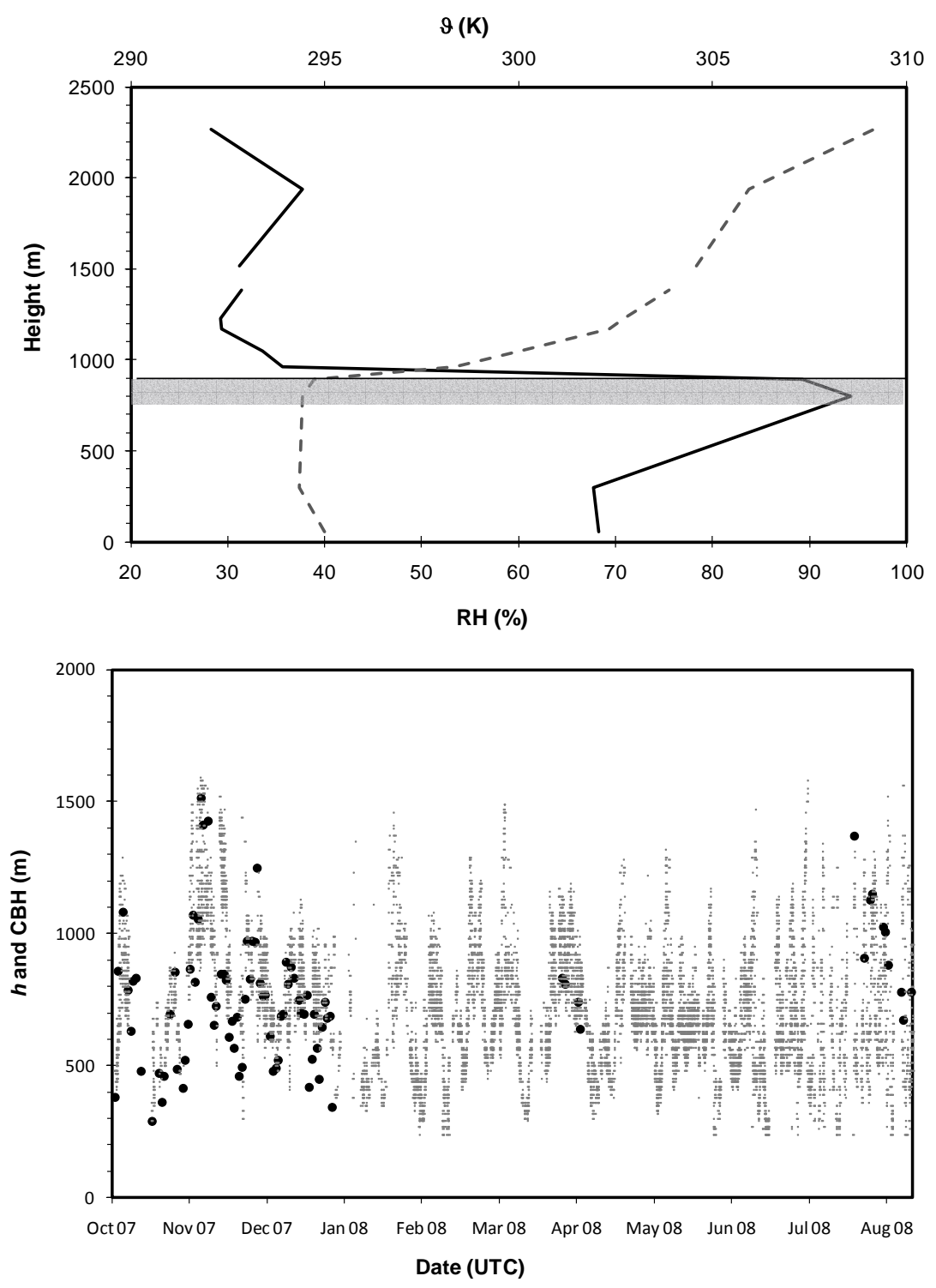

Figure 6. (a) Potential temperature (dotted line) and relative humidity (RH, solid line). Grey shaded area indicates cloud layer. (b) Comparison of ceilometer CBH (grey lines) and radiosonde $h$ (black circles). 

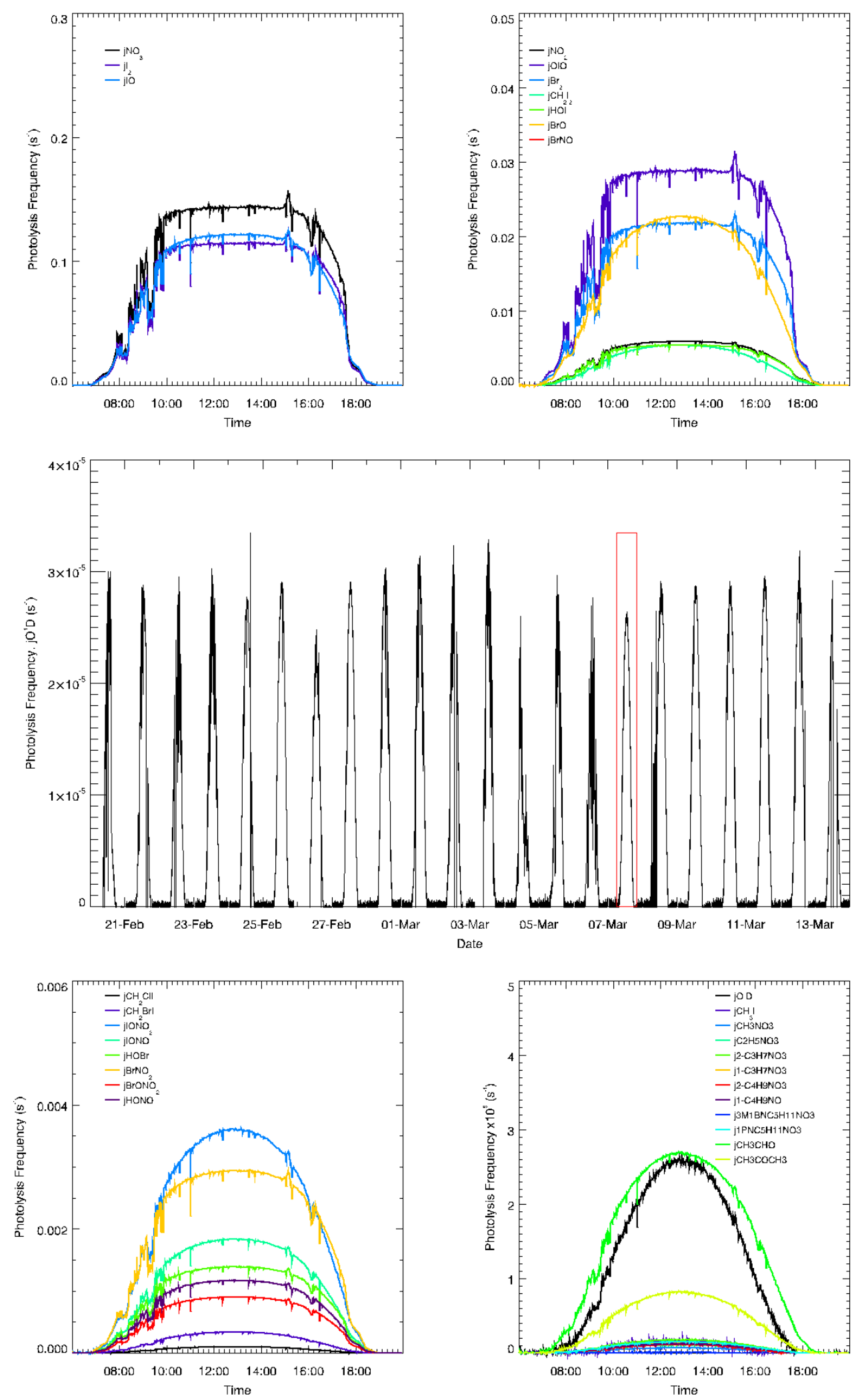

Figure 7. Photolysis values for various species derived from spectral radiometers during SOS1 and focussing in on the $7^{\text {th }}$ March 2009 


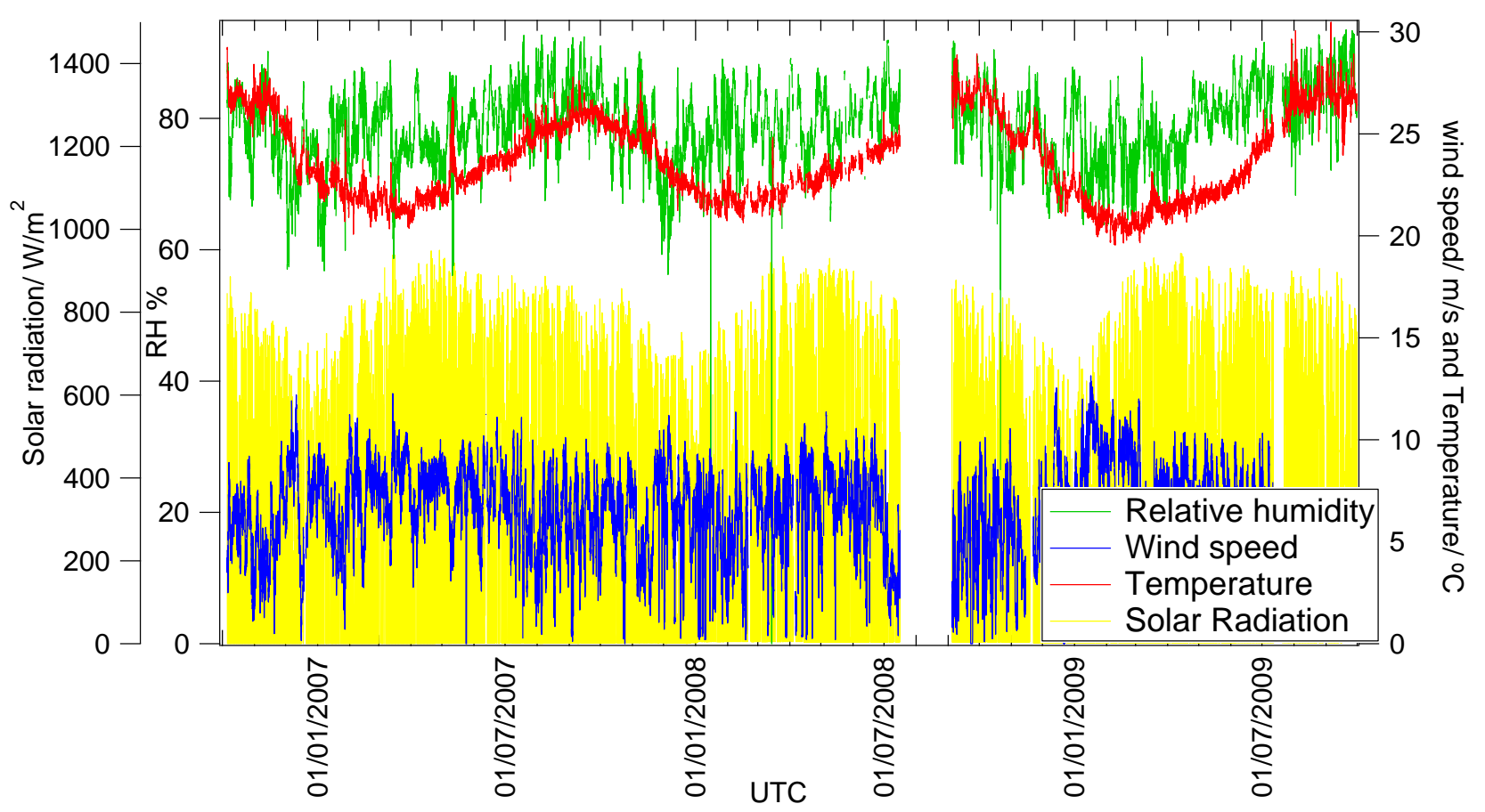

Figure 8. Solar radiation, wind speed, temperature and relative humidity at Cape Verde
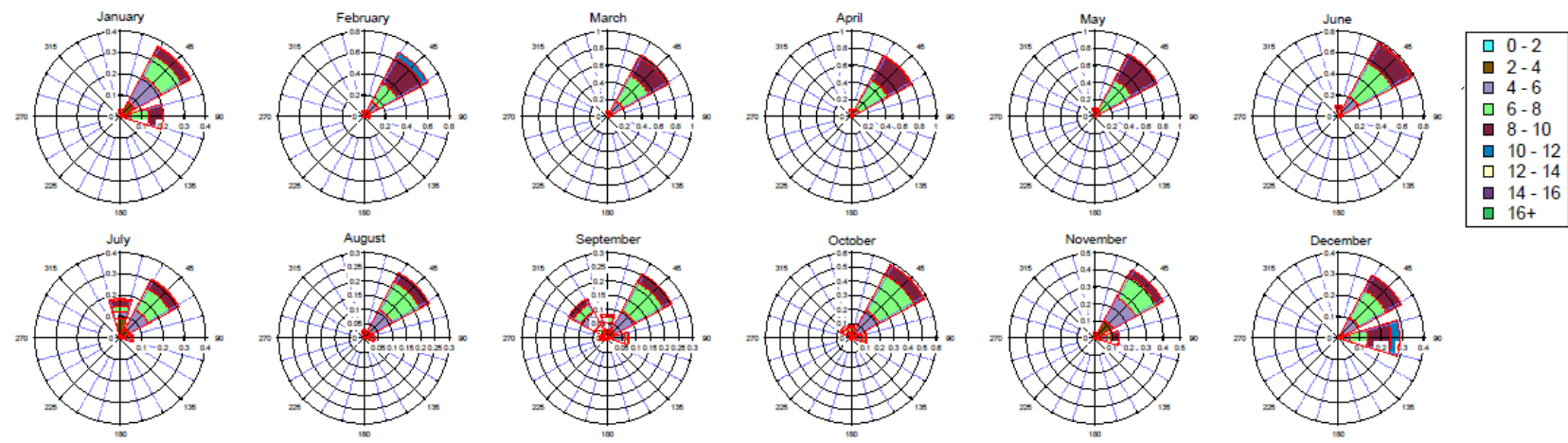

Figure 9. Monthly wind roses for all 3 years of measurements, coloured by wind speed. 


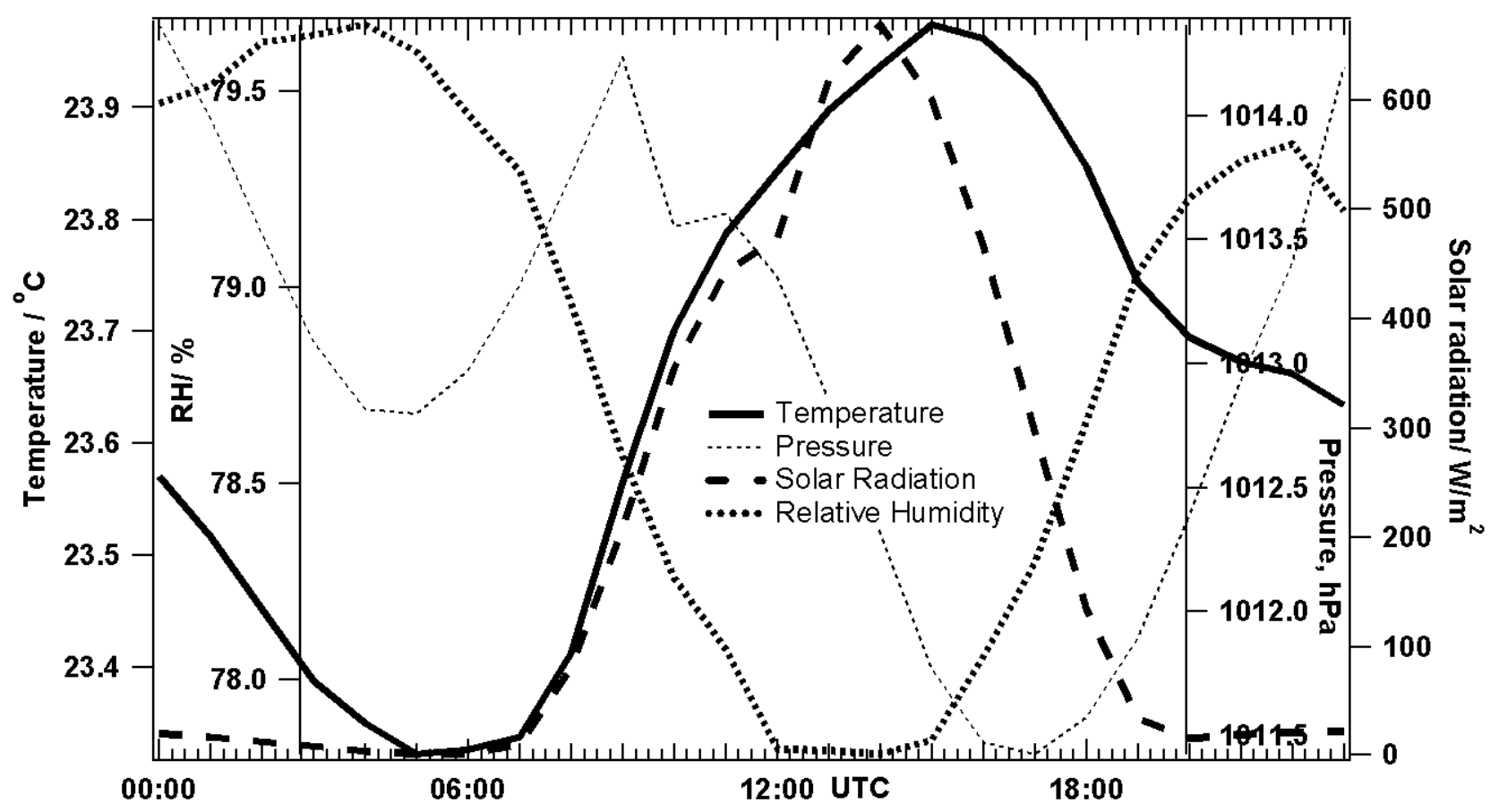

Figure 10. Three year average diurnal cycles (UTC time (local +1 hour)) for temperature, relative humidity, pressure and solar radiation
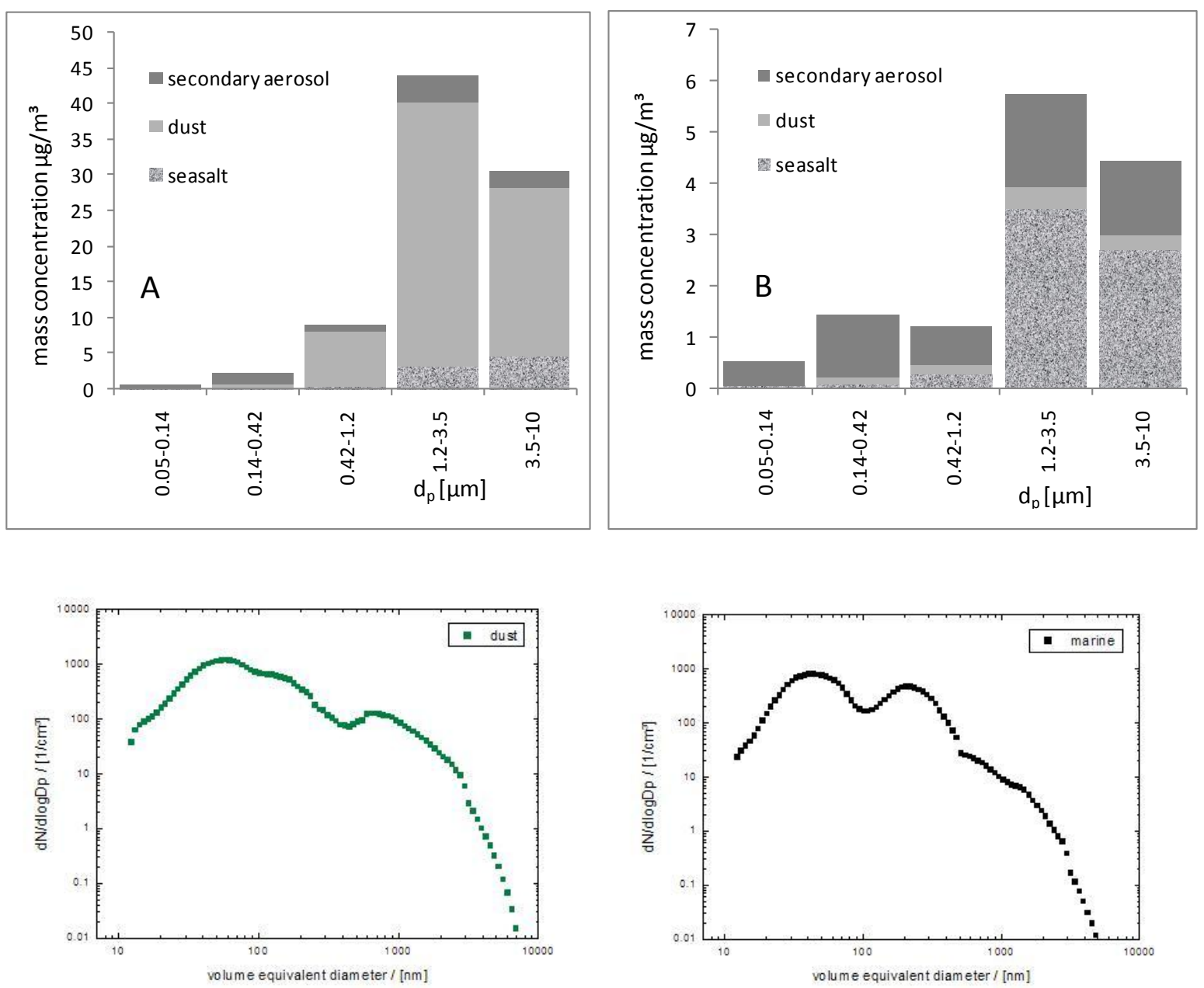
Figure 11. Size ranges of aerosol samples and attribution of secondary aerosol, dust and sea salt from a) A high dust day $\left(8^{\text {th }}\right.$ December 2007, air masses arriving from the Sahara) and b) A marine influenced day (12 $2^{\text {th }}$ June 2007 , air masses arriving from the northern Atlantic Ocean). Below are the size distributions of a dust event $\left(25^{\text {th }}-26^{\text {th }}\right.$ November 2008), showing higher concentration for diameters larger $800 \mathrm{~nm}$ (coarse mode) and a nearly monomodal distribution for diameters smaller than $500 \mathrm{~nm}$; and a marine event $\left(6^{\text {th }}-8^{\text {th }}\right.$ July 2008), showing a typical bimodal distribution for diameters smaller $500 \mathrm{~nm}$ (Aitken and accumulation modes) which contribute to non sea salt (nss) sulfate. The coarse mode is smaller during the marine event, indicating that it contains predominantly sea salt particles.

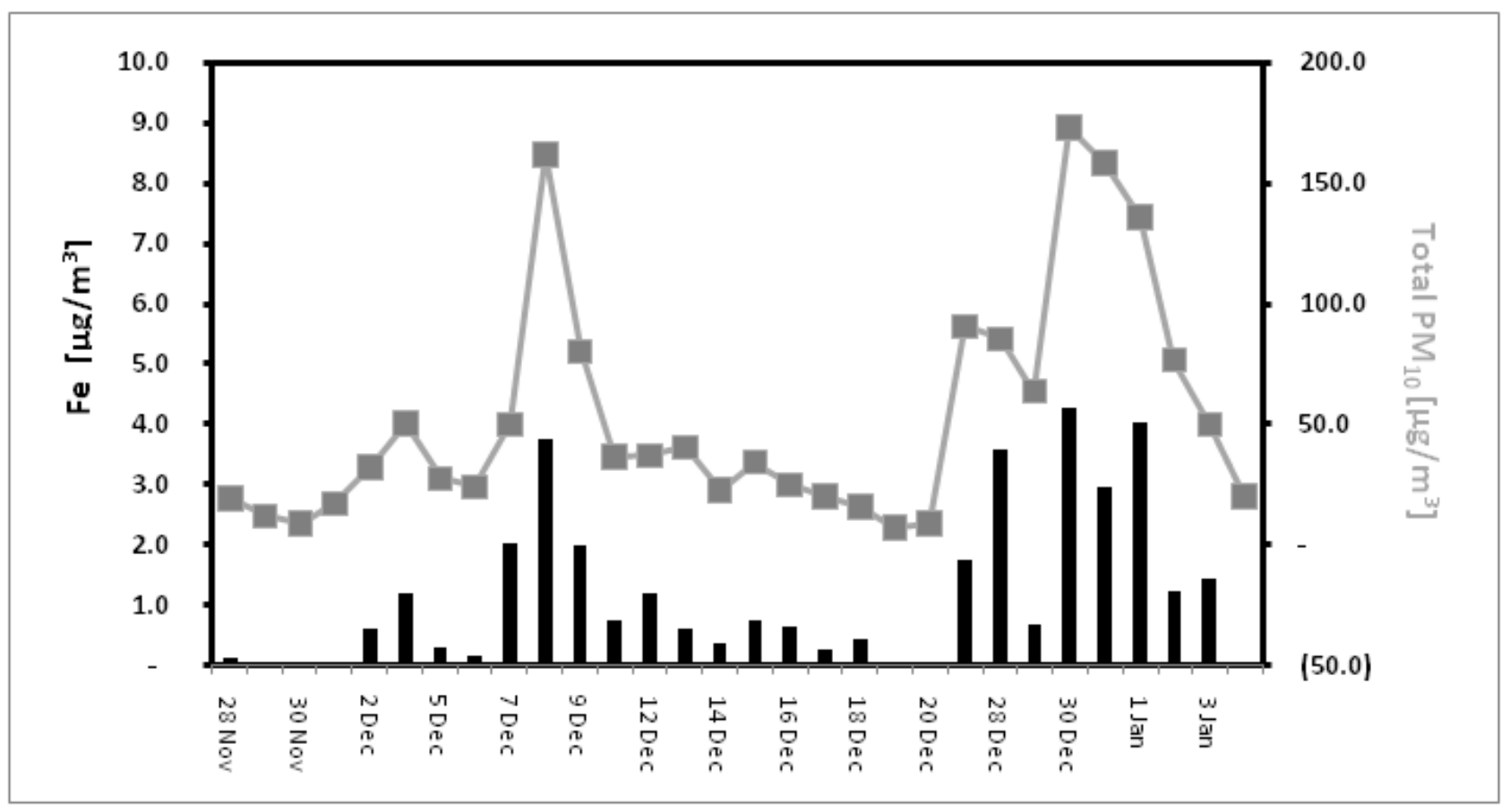

Figure 12. Iron and total $\mathrm{PM}_{10}$ concentration collected by the 5-stage Berner impactor during one intensive campaign, winter 2007. 


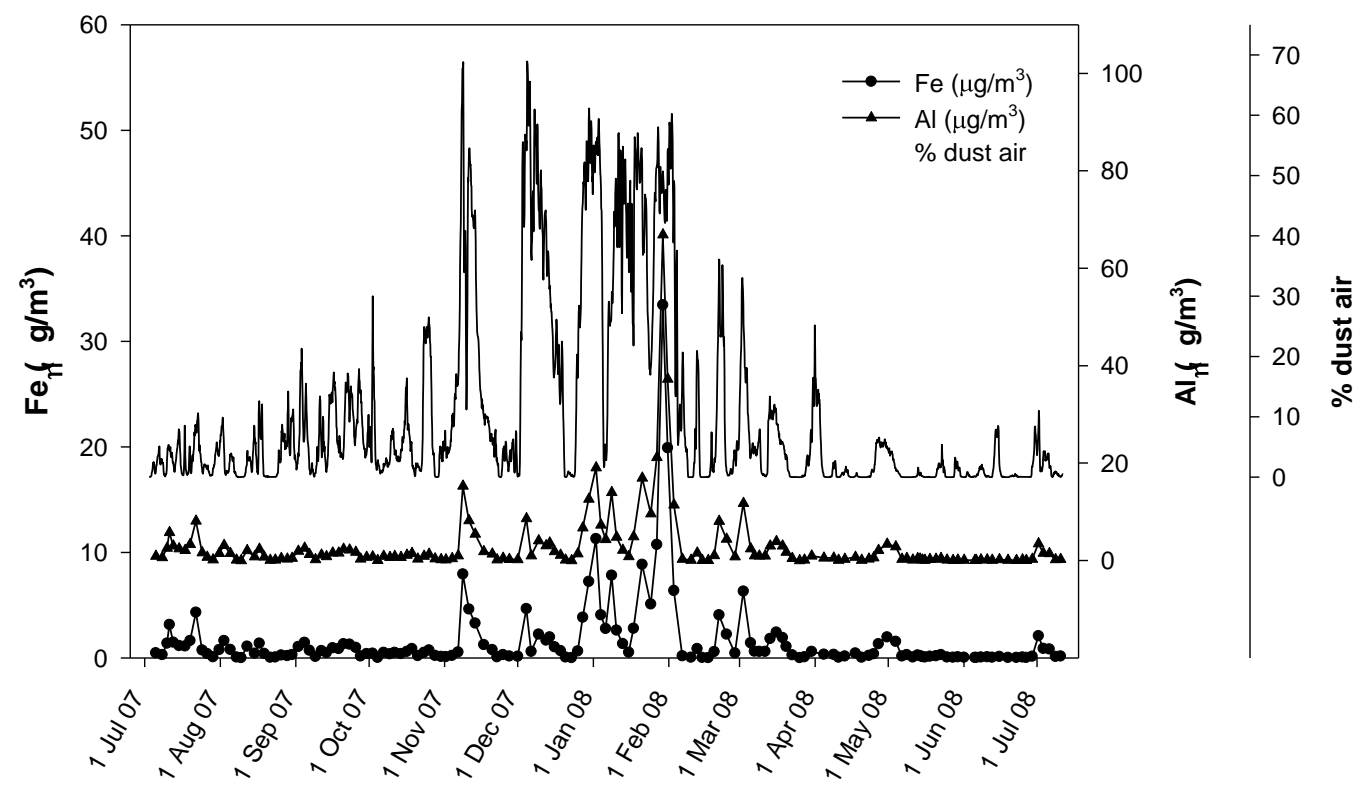

Figure 13. Total $\mathrm{Fe}$ and $\mathrm{Al}$ concentrations in dust collected with the low volume sampler at the CVAO between $2^{\text {nd }}$ July 2007 and $11^{\text {th }}$ July 2008 together with the percentage of particles originating from the Sahara as calculated using the NAME model. Concentrations have been normalised to sample air volume.

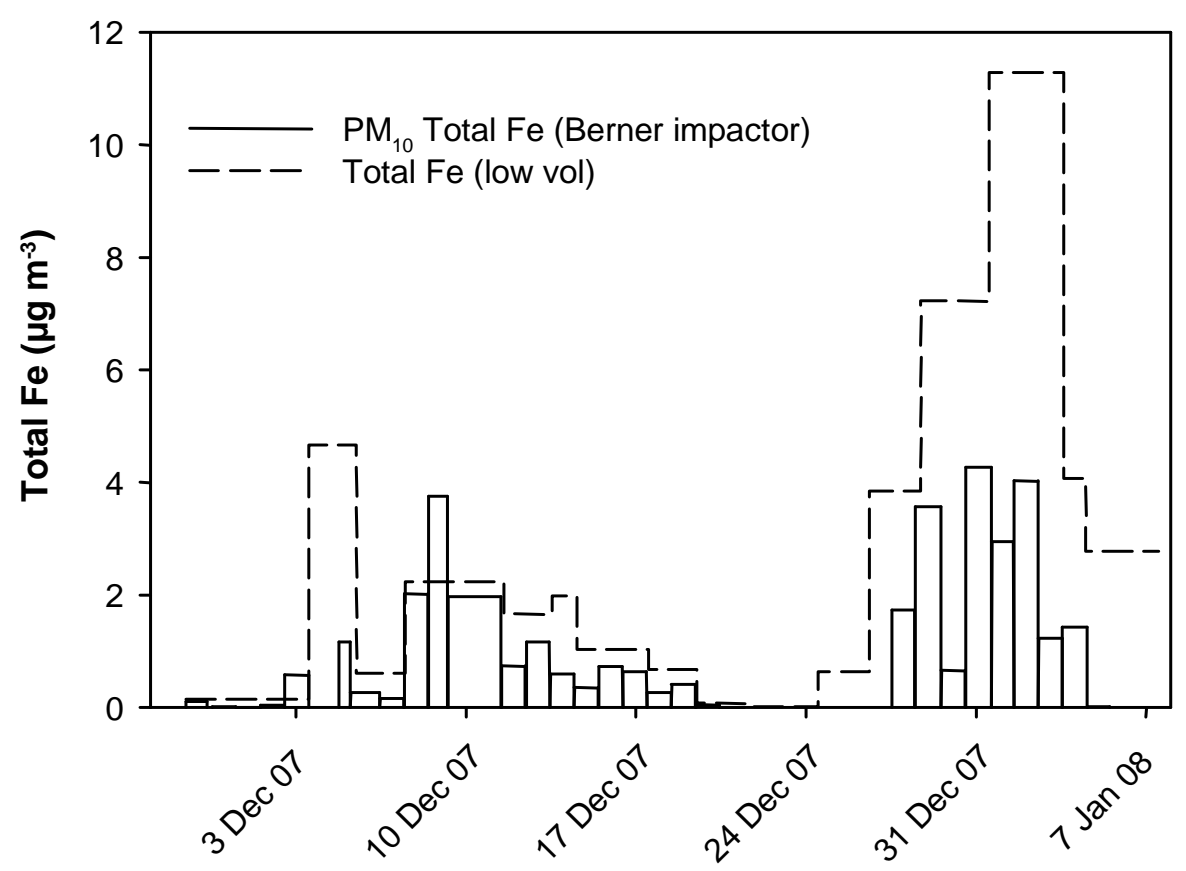

Figure 14. Comparison of $\mathrm{PM}_{10}$ total $\mathrm{Fe}$ concentrations in samples collected using a 5-stage Berner cascade impactor and the total $\mathrm{Fe}$ concentrations in samples collected using a low volume sampler for the period between $28^{\text {th }}$ November 2007 and $7^{\text {th }}$ January 2008. Variable width bars have been used to indicate the sampling duration for the $\mathrm{PM}_{10}$ data (no sampling was undertaken between $3^{\text {rd }}-4^{\text {th }}$ December, $21^{\text {st }}-27^{\text {th }}$ December, or after $5^{\text {th }}$ January). A dashed line indicates the measured Fe concentrations and sampling duration of samples collected with the low volume sampler, for which there was no break in sampling, but sampling durations were usually significantly longer than for the Berner cascade impactor $\mathrm{PM}_{10}$ data. 


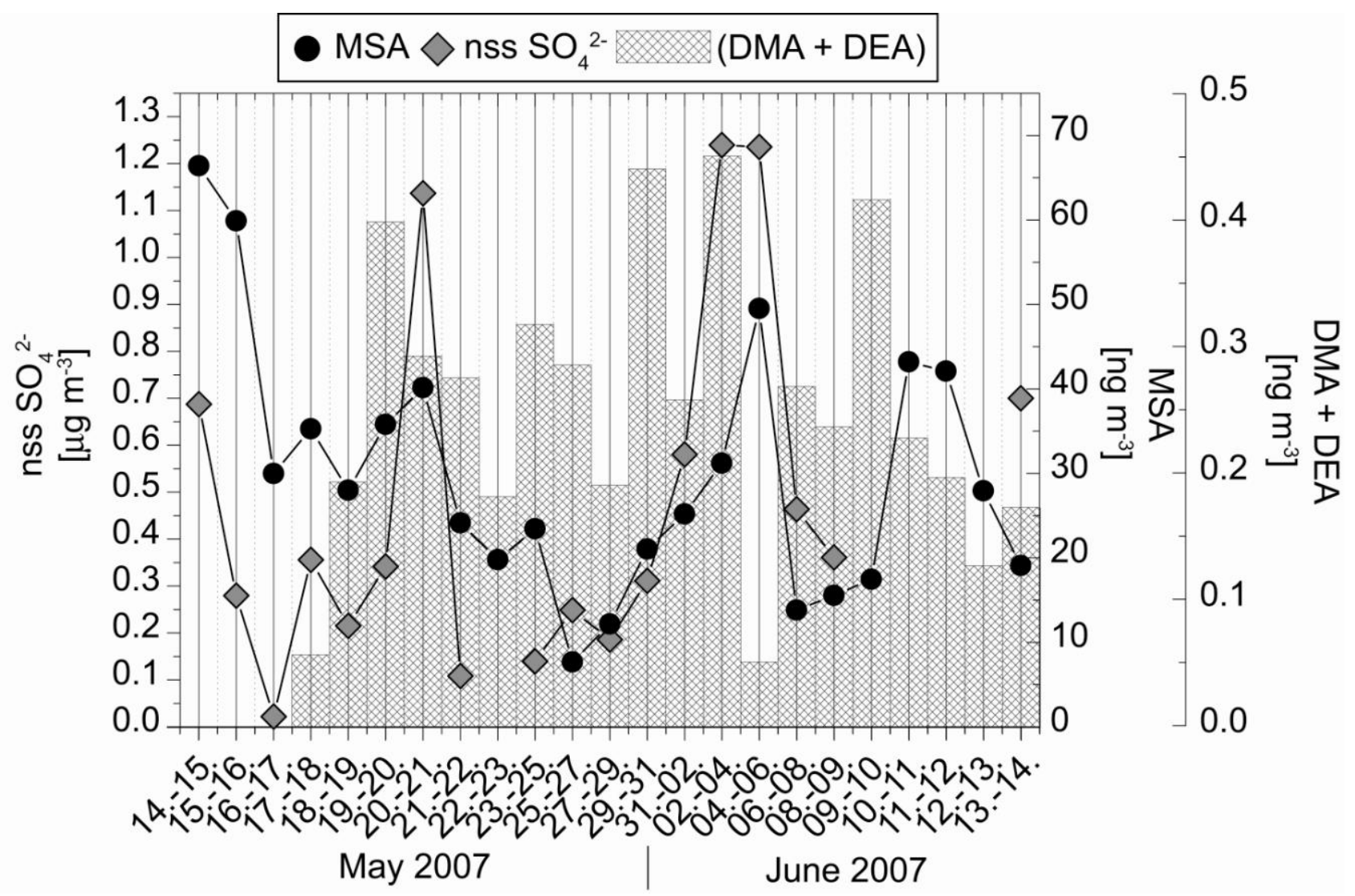

Figure 15. MSA, nss $\mathrm{SO}_{4}{ }^{2-}$ and Amines (DMA and DEA) for May and June 2007 (samples are shown as average over 2 or 3 day sampling periods) 


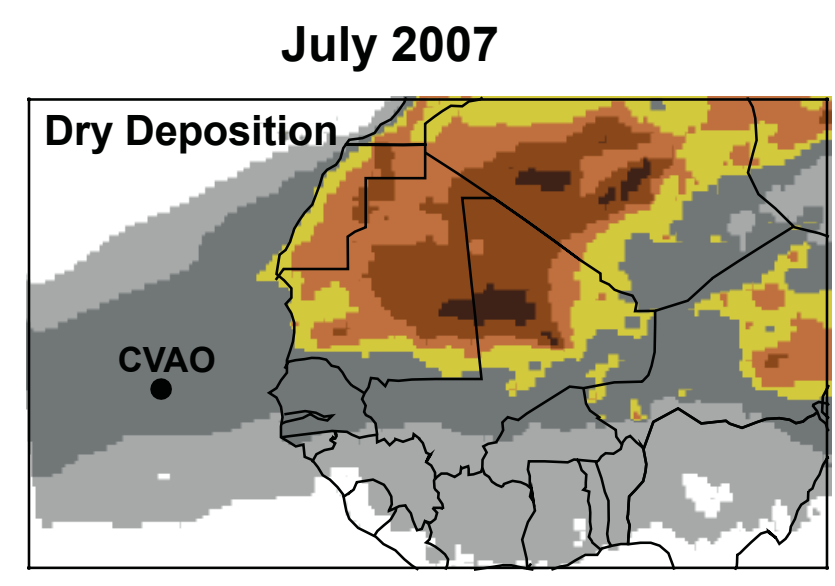

\section{January 2009}
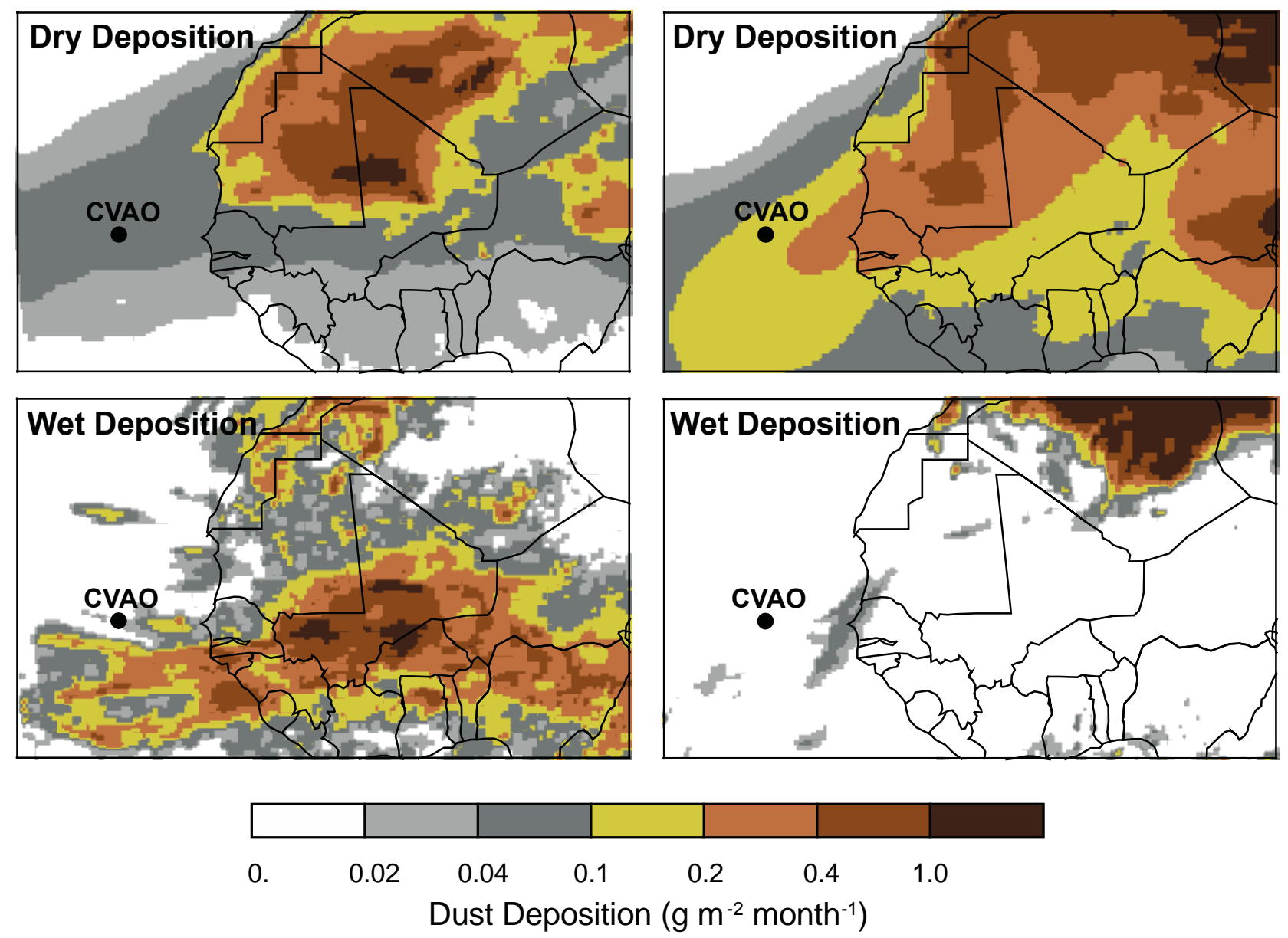

Figure 16. Total dry (top) and wet (bottom) deposition of Saharan dust $\left[\mathrm{g} \mathrm{m}^{-2}\right]$ for July 2007 (left) and January 2009 (right) simulated by COSMO-MUSCAT. 

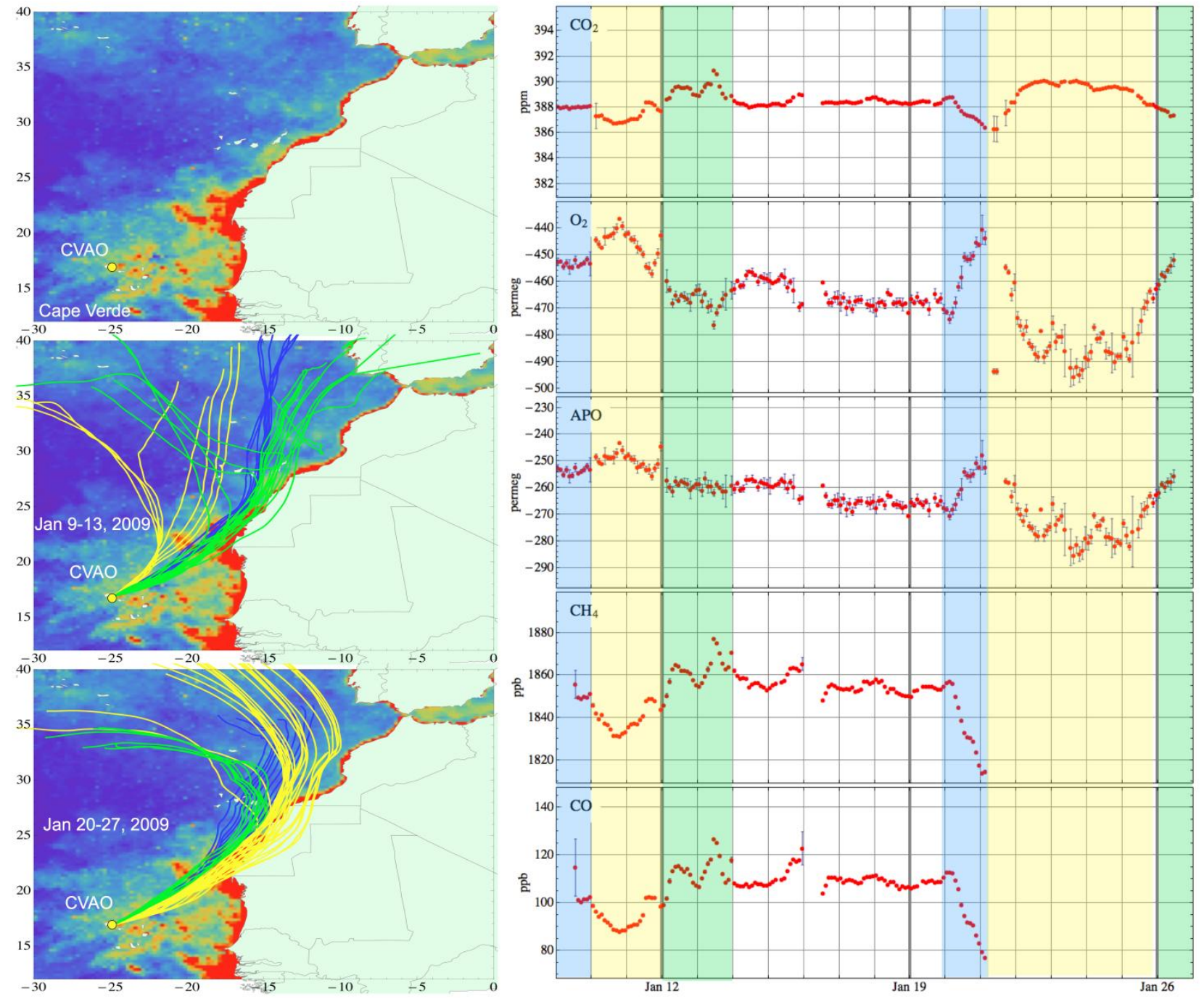

Figure 17. Left-hand side panel: map of ocean colour with respect to chlorophyll content for January 2009, with red colours corresponding to the highest concentrations $\left([\mathrm{CHL}]>1 \mathrm{mg} / \mathrm{m}^{-}{ }^{3}\right.$ ). Back trajectories of air masses arriving at the CVAO (computed with the HYSPLIT4 model) are shown in different colours to denote their origin. Right-hand side panel: Atmospheric measurements of $\mathrm{CO}_{2}, \mathrm{O}_{2} / \mathrm{N}_{2}$, APO (Atmospheric Potential Oxygen), $\mathrm{CH}_{4}$ and $\mathrm{CO}$ shown as 2hourly trimmed averages (including 50\% of the innermost data points). Concentration units: $\mathrm{CO}_{2}$ is shown in 'ppm', $\mathrm{CH}_{4}$ and $\mathrm{CO}$ in 'ppb', and $\mathrm{O}_{2} / \mathrm{N}_{2}$ ratios and APO in 'per meg' units (a change of 1 per meg in $\mathrm{O}_{2}$ corresponds to a change of $\sim 4.8 \mathrm{ppm}$ in $\mathrm{CO}_{2}$ ). The $\mathrm{CO}_{2}$ and $\mathrm{O}_{2}$ are plotted so that changes can be compared on a mole per mole basis. APO is calculated from continuous measurements of $\mathrm{CO}_{2}$ and $\mathrm{O}_{2}\left(\mathrm{APO}=\mathrm{O}_{2}+1.1 \mathrm{CO}_{2}\right.$, where 1.1 is an average global $\mathrm{O}_{2} / \mathrm{CO}_{2}$ exchange ratio for terrestrial biosphere (Severinghaus 1995). The coloured sections correspond to the colours of the back trajectories in the left-hand side panel, and denote differences in the air mass origin. 

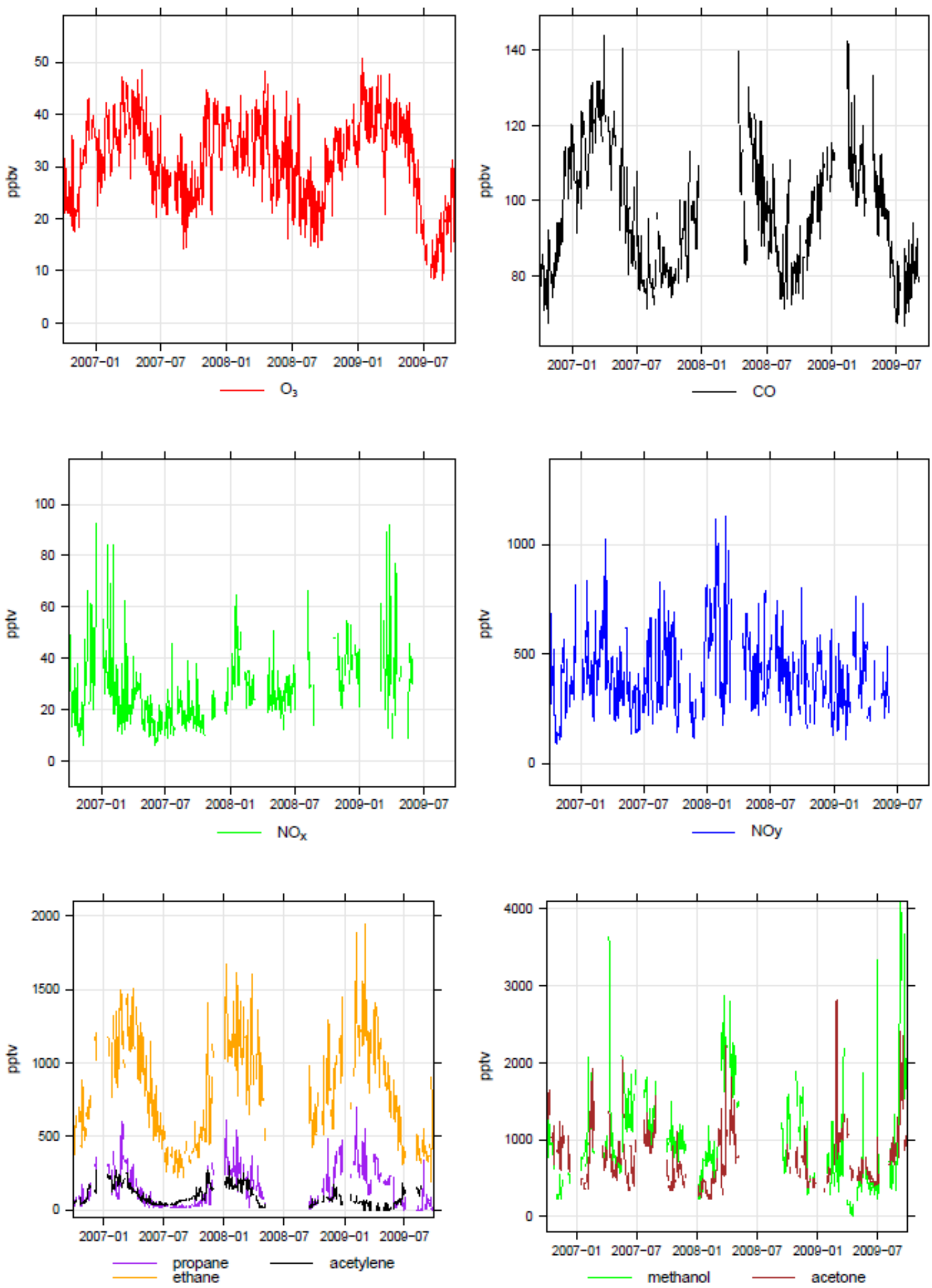

Figure 18. Daily averaged $\mathrm{O}_{3}, \mathrm{CO}, \mathrm{NO}_{\mathrm{x}}, \mathrm{NO}_{\mathrm{y}}$ and $\mathrm{VOC}$ (propane, ethane, acetylene, acetone and methanol) mixing ratios. 

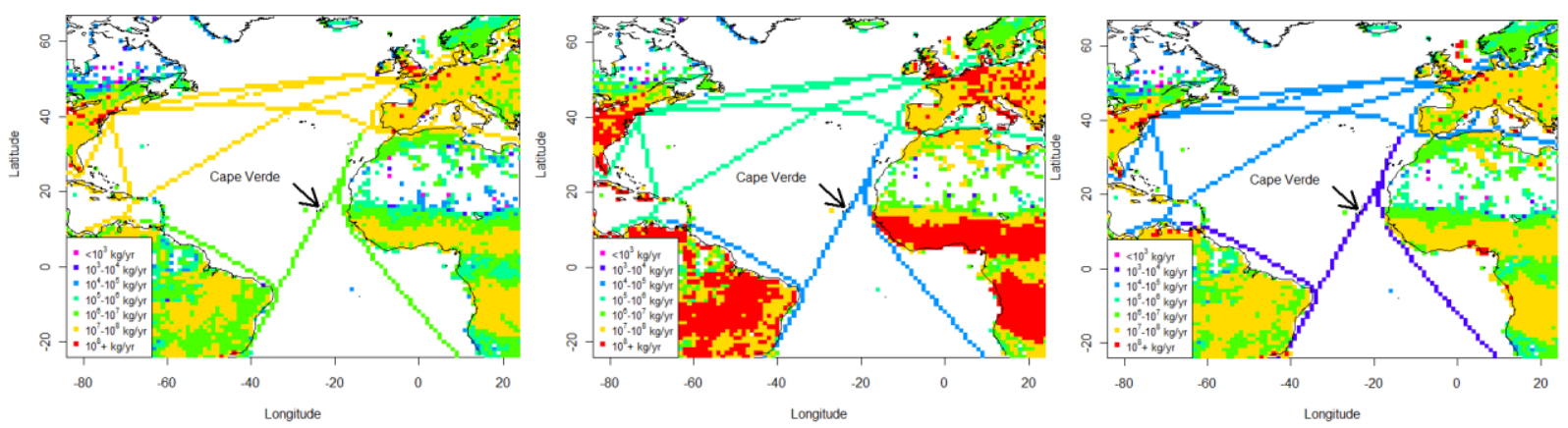

Figure 19. NOx, CO and NMVOC emissions. Taken from (Mace et al., 2011) using the EDGAR emissions inventory (Olivier and Visschedijk 1996).

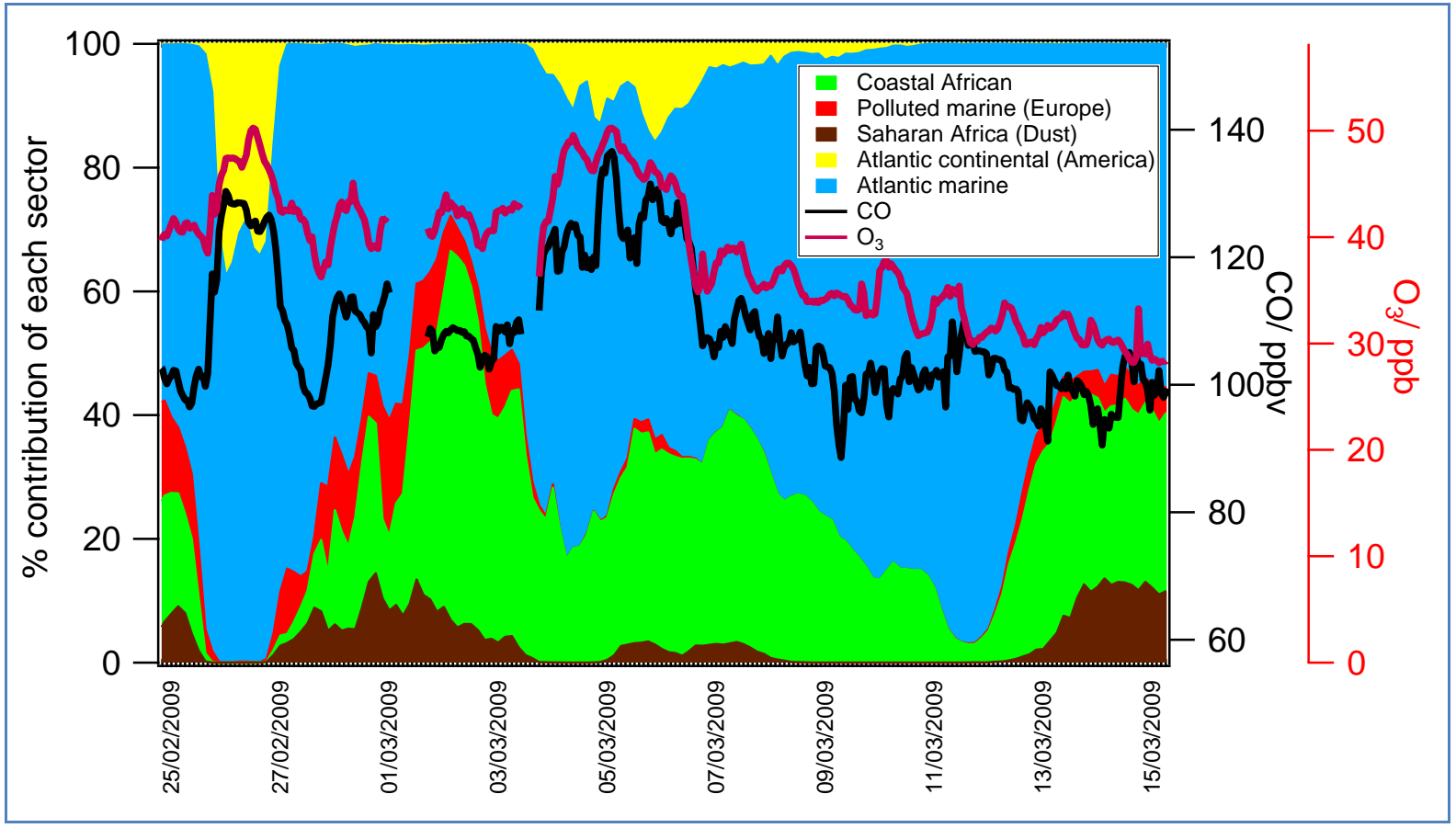

Figure 20. Hourly averaged ozone and $\mathrm{CO}$ mixing ratios and percentage contributions of the 3 hourly trajectory classifications during February-March 2009. 


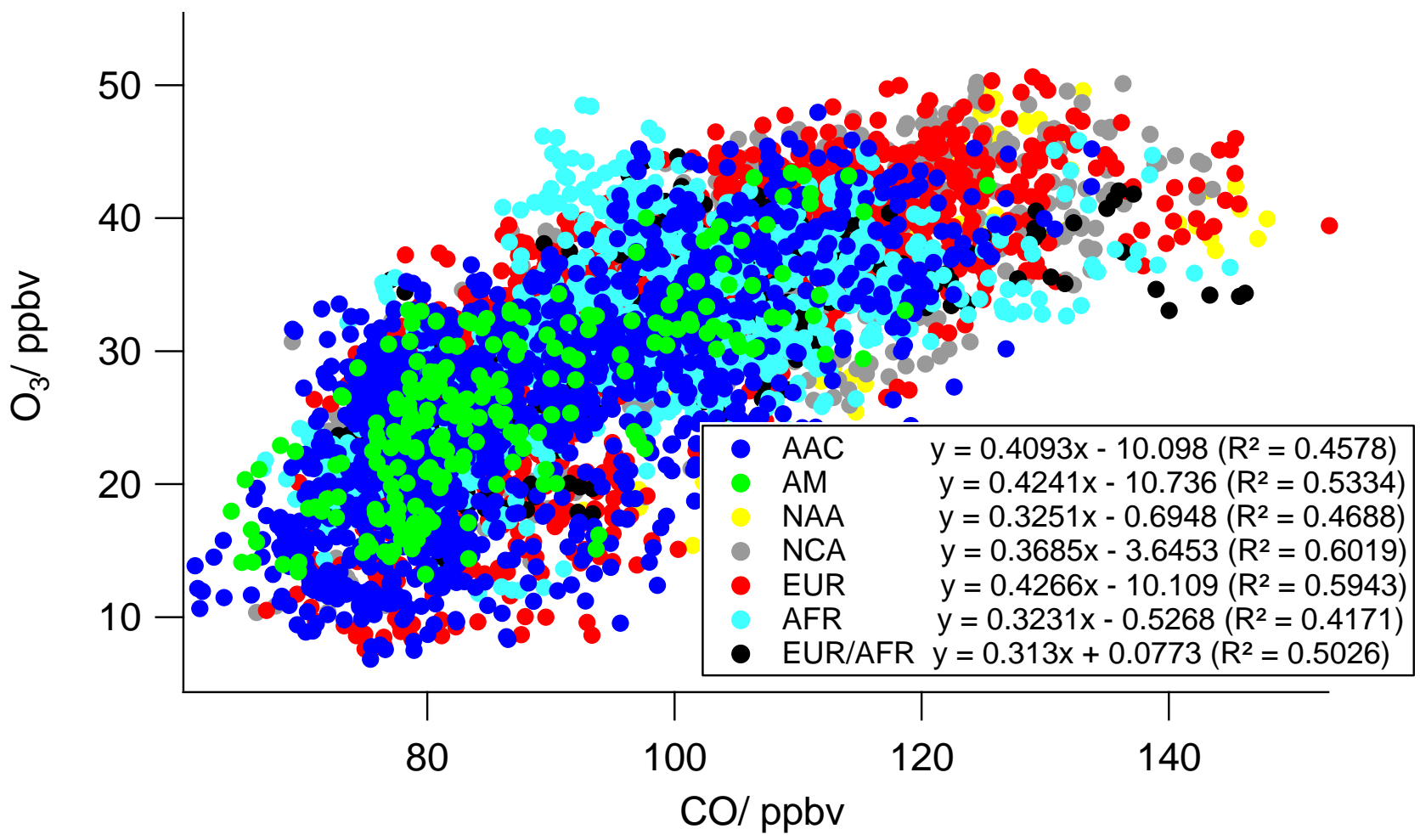

Figure 21. $\mathrm{O}_{3} / \mathrm{CO}$ ratios segregated by air mass classification

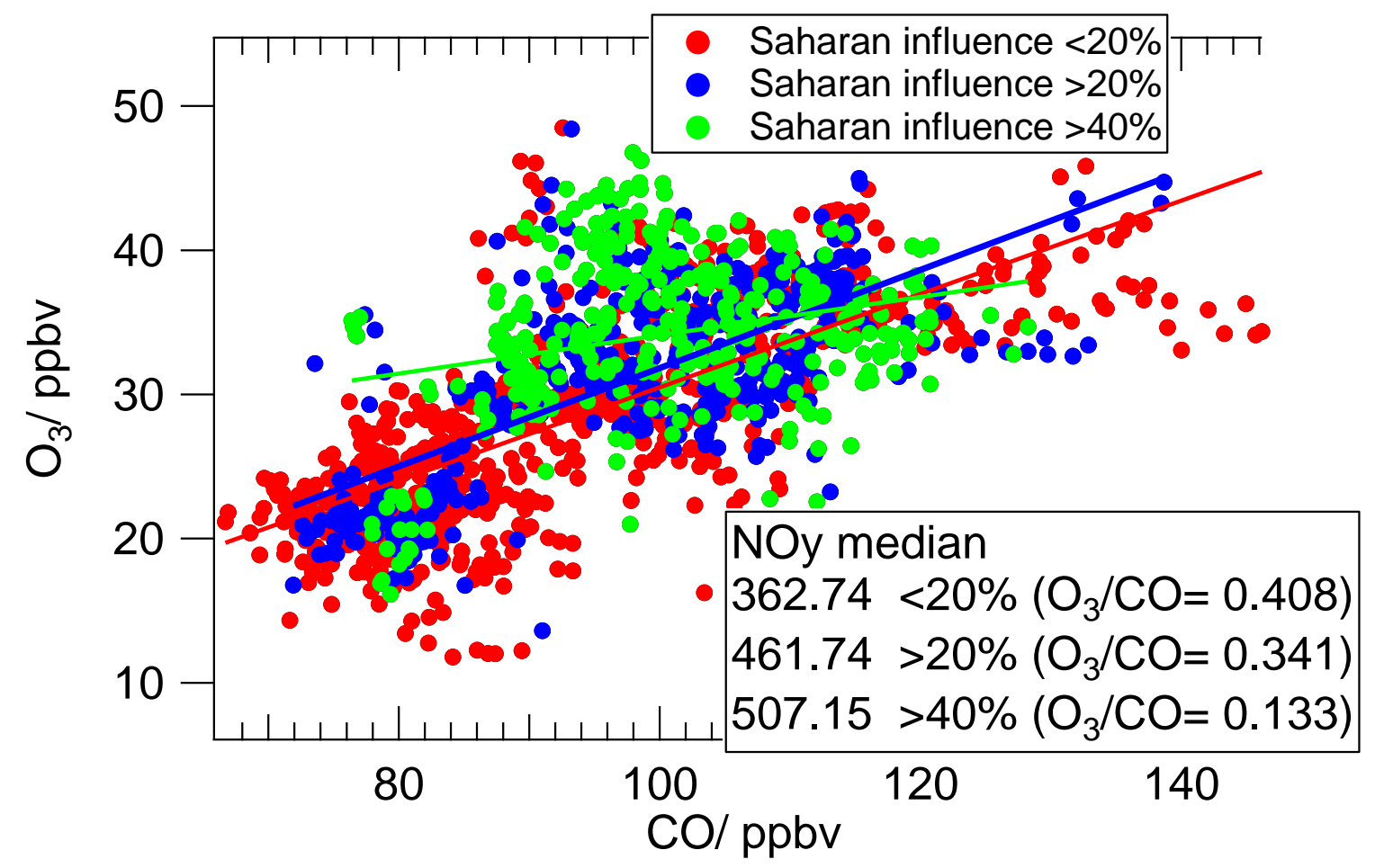

Figure 22. $\mathrm{CO}$ vs. $\mathrm{O}_{3}$ concentrations coloured according to the percentage of their time spent over the Saharan region. 


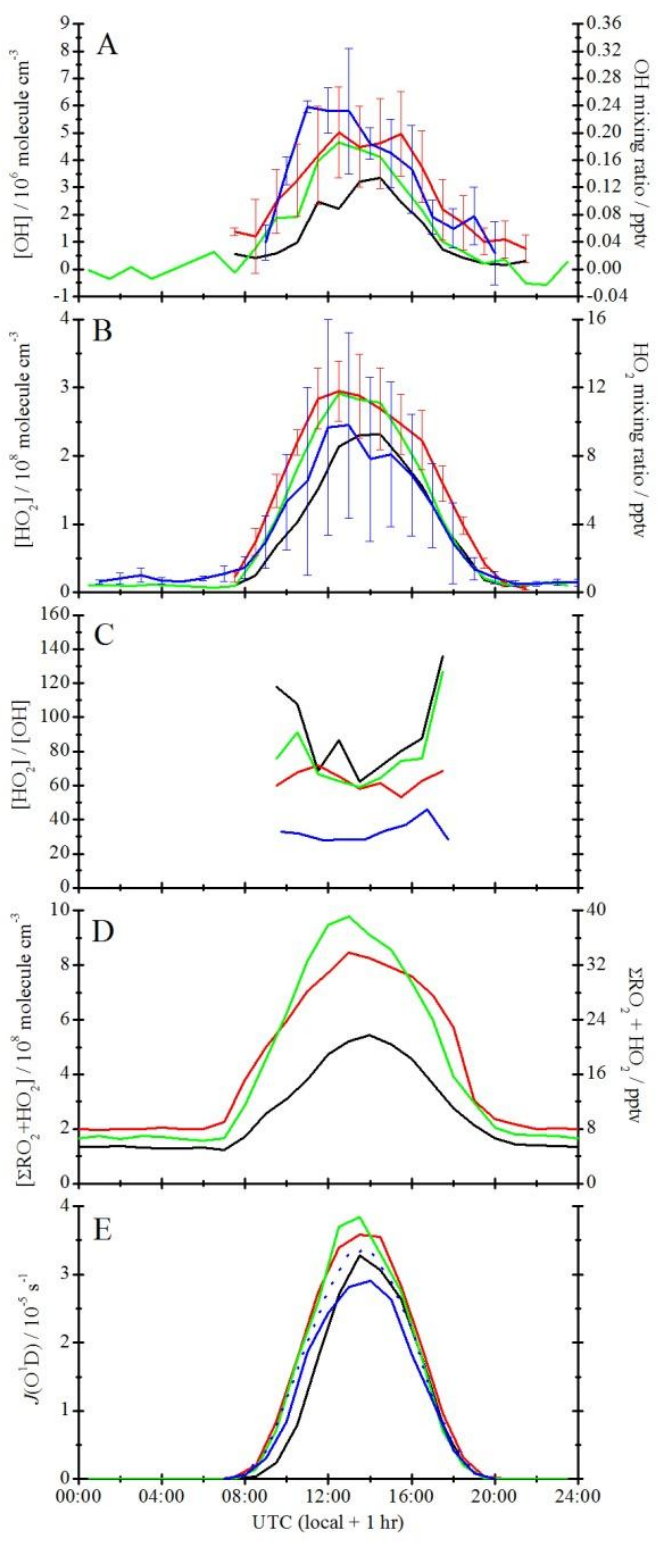

Figure 23. Median hourly-averaged $\mathrm{OH}, \mathrm{HO}_{2}$ (as measured by the FAGE instrument) and $J\left(\mathrm{O}^{1} \mathrm{D}\right)$ levels recorded during SOS1 (black line), SOS2 (red line), SOS3 (green line) and RHaMBLe (blue lines); (A) concentrations and mixing ratios of $\mathrm{OH}$ (for clarity, only the error bars showing the $1 \sigma$ of the hourly-averaged data for SOS2 and RHaMBLe are shown); (B) concentrations and mixing ratios of $\mathrm{HO}_{2}$ (only the error bars showing the $1 \sigma$ of the hourlyaveraged data for SOS2 and RHaMBLe are displayed); (C) the ratios of $\left[\mathrm{HO}_{2}\right]$ to $[\mathrm{OH}]$ (only values for between 8 am and $5 \mathrm{pm}$ have been shown for clarity); (D) PERCA $\mathrm{HO}_{2}+\Sigma \mathrm{RO}_{2}$; (E) values of $J\left(\mathrm{O}^{1} \mathrm{D}\right)$ measured using the University of Leeds' radiometer (the blue solid is for OH-measuring period, blue dotted is for $\mathrm{HO}_{2}$ measuring period during RHaMBLe, respectively). 


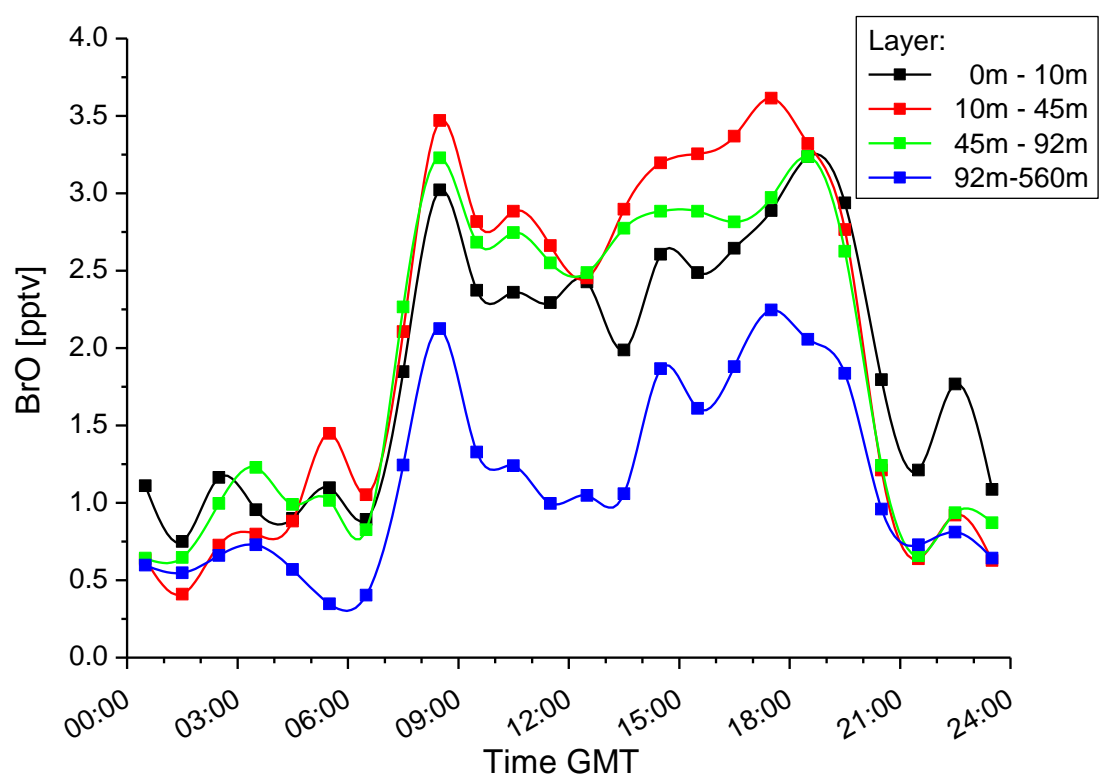

Figure 24. Averaged daily cycle of BrO concentration with the UOH LP-DOAS instrument for different layer heights (vertical profile) derived from measurements to retro reflectors at different heights on the mountain of Monte Verde between the $12^{\text {th }}$ and $20^{\text {th }}$ June 2010. A maximum peak concentration in the morning after sunrise and evening at sunset with a local minimum at noon was observed. 
Table 1. CVAO instruments, their performance and data coverage

\begin{tabular}{|c|c|c|c|c|}
\hline $\begin{array}{l}\text { Measurement } \\
\text { Species }\end{array}$ & Instrument & Performance & $\begin{array}{l}\text { Timescale of } \\
\text { measurements }\end{array}$ & $\begin{array}{l}\text { Responsible } \\
\text { Institution }\end{array}$ \\
\hline \multicolumn{5}{|c|}{ Permanent Measurements } \\
\hline $\begin{array}{l}\text { Meteorological } \\
\text { data at } 4 \mathrm{~m}, 10 \mathrm{~m} \\
\text { and } 30 \mathrm{~m}\end{array}$ & $\begin{array}{l}\text { Automatic Weather } \\
\text { Station }\end{array}$ & & Oct 06 - present & $\begin{array}{l}\text { NCAS, University of } \\
\text { York, UK }\end{array}$ \\
\hline Solar radiation & Spectral Radiometer & $\begin{array}{l}280->950 \mathrm{~nm} \\
\text { (UV and VIS- } \\
\text { Band) }\end{array}$ & Apr 08-present & $\begin{array}{l}\text { Institut für } \\
\text { Meereskunde, Hamburg, } \\
\text { Germany }\end{array}$ \\
\hline $\mathrm{JO}^{\mathrm{I}} \mathrm{D}$ & Radiometer & $\begin{array}{l}1 \text { min integration } \\
\text { time }\end{array}$ & $\begin{array}{l}\text { Jan - Feb 07, May - } \\
\text { Jun 07, Apr } 08 \text { - } \\
\text { present }\end{array}$ & $\begin{array}{l}\text { University of Leeds, UK } \\
\text { NCAS, University of } \\
\text { York, UK }\end{array}$ \\
\hline Ozone & $\begin{array}{l}\text { UV Absorption TEI } \\
49 \mathrm{C} \text { and } 49 \mathrm{i}\end{array}$ & $\begin{array}{l}1 \text { min integration } \\
\text { time, } 1 \mathrm{ppb} \\
\text { detection limit } \\
\text { (dl) }\end{array}$ & Oct 06 - present & $\begin{array}{l}\text { NCAS, University of } \\
\text { York, UK }\end{array}$ \\
\hline Carbon Monoxide & $\begin{array}{l}\text { VUV Fluorescence, } \\
\text { Aerolaser } 5001\end{array}$ & $\begin{array}{l}1 \text { min integration } \\
\text { time, } 2 \text { ppb dl }\end{array}$ & Oct 06 - present & $\begin{array}{l}\text { NCAS, University of } \\
\text { York, UK }\end{array}$ \\
\hline $\mathrm{NO}, \mathrm{NO}_{2}, \mathrm{NO}_{\mathrm{y}}$ & $\begin{array}{l}\text { Chemiluminescence, } \\
\text { Air Quality Design } \\
\text { Inc }\end{array}$ & $\begin{array}{l}1 \mathrm{hr} \text { integration } \\
\text { time, } 1.5,4,3 \\
\text { pptv dl for } \mathrm{NO} \text {, } \\
\mathrm{NO}_{2}, \mathrm{NO}_{\mathrm{y}} \\
\text { respectively }\end{array}$ & Oct 06 - present & $\begin{array}{l}\text { NCAS, University of } \\
\text { York, UK }\end{array}$ \\
\hline $\begin{array}{l}\text { Speciated NOy - } \\
\sum \text { PANs, nitrate } \\
\text { aerosol, } \sum \text { alkyl } \\
\text { nitrates }\end{array}$ & $\begin{array}{l}\text { Heated quartz inlets- } \\
\text { Chemiluminescence }\end{array}$ & $\begin{array}{l}1 \mathrm{hr} \text { integration } \\
\text { time, } \sim 10 \mathrm{pptv} \text { dl }\end{array}$ & Apr 09 - present & $\begin{array}{l}\text { NCAS, University of } \\
\text { York, UK }\end{array}$ \\
\hline $\begin{array}{l}\mathrm{C}_{2}-\mathrm{C}_{8} \text { NMVOCs } \\
\text { and DMS }\end{array}$ & $\begin{array}{l}\text { Dual channel GC- } \\
\text { FID }\end{array}$ & $\begin{array}{l}1 \mathrm{hr} \text { integration } \\
\text { time, } 2.5,1 \mathrm{pptv} \\
\mathrm{dl} \text { for } \mathrm{C}_{2}-\mathrm{C}_{4} \text { and } \\
>\mathrm{C}_{4} \text { respectively }\end{array}$ & Oct 06 - present & $\begin{array}{l}\text { NCAS, University of } \\
\text { York, UK }\end{array}$ \\
\hline $\begin{array}{l}\text { Methanol, acetone, } \\
\text { acetaldehyde }\end{array}$ & $\begin{array}{l}\text { Dual channel GC- } \\
\text { FID }\end{array}$ & $\begin{array}{l}1 \mathrm{hr} \text { integration } \\
\text { time, } 3,7,18, \\
\text { pptv dl for } \\
\text { acetone, } \\
\text { methanol and } \\
\text { acetaldehyde and } \\
\text { respectively }\end{array}$ & Oct 06 - present & $\begin{array}{l}\text { NCAS, University of } \\
\text { York, UK }\end{array}$ \\
\hline Halocarbons & GC-MS & $\begin{array}{l}30 \text { min } \\
\text { integration time, } \\
0.05 \mathrm{pptv} \mathrm{dl}\end{array}$ & $\begin{array}{l}\text { May 07, Sep 07- } \\
\text { Jan 08, Sept 09- } \\
\text { May } 10\end{array}$ & University of Bristol, UK \\
\hline $\begin{array}{l}\text { Chemical } \\
\text { characterisation of } \\
\text { aerosol } \mathrm{PM}_{10}, \\
\mathrm{Mg}^{2+}, \mathrm{Ca}^{2+}, \mathrm{NH}_{4}^{+}, \\
\mathrm{Na}^{+}, \mathrm{K}^{+}, \mathrm{Br}^{-}, \mathrm{Cl}^{-}, \\
\mathrm{NO}_{3}^{-}, \mathrm{SO}_{4}^{2-}, \mathrm{OC}, \\
\mathrm{EC}, \text { oxalate and in } \\
\text { campaigns other } \\
\text { dicarboxylic acids, }\end{array}$ & $\begin{array}{l}\text { HiVOL Sampler, } \\
\text { Digitel DHA-80 } \\
\text { Subsequent analysis } \\
\text { Ion chromatography, } \\
\text { thermographic } \\
\text { methods, } \\
\text { CE-MS, and GC-MS, } \\
5 \text { stage Berner } \\
\text { Impactor, size }\end{array}$ & $\begin{array}{l}1,1,1,1,2,2,1 \\
5,8,9,3,5 \\
\mathrm{ng} \mathrm{m}^{-3} \mathrm{dl}\end{array}$ & $\begin{array}{l}\text { Nov 06-present } \\
\text { only during } \\
\text { campaigns (1-2 } \\
\text { month per year) }\end{array}$ & $\begin{array}{l}\text { Leibniz-Institut für } \\
\text { Troposphärenforschung, } \\
\text { Germany }\end{array}$ \\
\hline
\end{tabular}




\begin{tabular}{|c|c|c|c|c|}
\hline $\begin{array}{l}\text { organic } \\
\text { compounds, } \\
\text { metals }(\mathrm{Ti}, \mathrm{Mn}, \mathrm{Fe}, \\
\mathrm{Ni}, \mathrm{Cu}, \mathrm{Zn}) \text { in five } \\
\text { size fractions }\end{array}$ & $\begin{array}{l}\text { segregated analysis, } \\
\text { TXRF for metal } \\
\text { analysis }\end{array}$ & & & \\
\hline $\begin{array}{l}\text { Physical } \\
\text { characterisation of } \\
\text { Aerosol } \\
\text { Size distribution } \\
(12 \mathrm{~nm}-10 \mu \mathrm{m}) \\
\text { and number } \\
\text { concentration }\end{array}$ & $\begin{array}{l}\text { SMPS }(10-800 \mathrm{~nm}) \\
\text { APS }(0.6-10 \mu \mathrm{m})\end{array}$ & 15 min sampling & May 07-present & $\begin{array}{l}\text { Leibniz-Institut für } \\
\text { Troposphärenforschung, } \\
\text { Germany }\end{array}$ \\
\hline $\begin{array}{l}\text { Aerosol Absorption } \\
\text { 300-800nm }\end{array}$ & MAAP & 1 hour & June 08- present & $\begin{array}{l}\text { Leibniz-Institut für } \\
\text { Troposphärenforschung, } \\
\text { Germany }\end{array}$ \\
\hline $\begin{array}{l}\mathrm{CH}_{4}, \mathrm{CO}_{2}, \mathrm{~N}_{2} \mathrm{O}, \\
\mathrm{CO}, \mathrm{SF}_{6} \text {, ratio of } \\
\mathrm{O}_{2} / \mathrm{N}_{2} \text {, and } \mathrm{Ar} / \mathrm{N}_{2} \\
\text { isotope ratios of } \\
{ }^{13} \mathrm{C}^{12} \mathrm{C} \text { and }{ }^{18} \mathrm{O} /{ }^{16} \mathrm{O} \\
\text { of } \mathrm{CO}_{2} \text { and } \mathrm{O}_{2}\end{array}$ & Flask sampling & $\begin{array}{l}0.7,30,0.3,1.4 \\
\text { ppbv dl for } \mathrm{CH}_{4} \\
\mathrm{CO}_{2}, \mathrm{~N}_{2} \mathrm{O}, \mathrm{CO} \\
\text { respectively }\end{array}$ & Jan 07-present & $\begin{array}{l}\text { Max-Planck-Institut für } \\
\text { Biogeochemie, Jena, } \\
\text { Germany }\end{array}$ \\
\hline $\begin{array}{l}\mathrm{O}_{2}, \mathrm{~N}_{2}, \mathrm{SF}_{6}, \mathrm{CH}_{4}, \\
\mathrm{~N}_{2} \mathrm{O}\end{array}$ & Gas Chromatograph & $\begin{array}{l}12 \text { minute } \\
\text { integration time, } \\
\text { Detection limits: } \\
\mathrm{CH}_{4}: 1 \mathrm{ppb} \\
\mathrm{CO}: 0.5-1 \mathrm{ppb} \\
\mathrm{SF}_{6}: 0.05-0.1 \mathrm{ppt} \\
\mathrm{N}_{2} \mathrm{O}: 0.1-0.2 \mathrm{ppb}\end{array}$ & June 08-present & $\begin{array}{l}\text { Max-Planck-Institut für } \\
\text { Biogeochemie, Jena, } \\
\text { Germany }\end{array}$ \\
\hline $\mathrm{CO}_{2}$ & NDIR & $\begin{array}{l}12 \text { minute } \\
\text { integration time, } \\
0.005 \mathrm{ppm} \mathrm{dl}\end{array}$ & June 08-present & $\begin{array}{l}\text { Max-Planck-Institut für } \\
\text { Biogeochemie, Jena, } \\
\text { Germany }\end{array}$ \\
\hline $\mathrm{O}_{2}$ & $\begin{array}{l}\mathrm{O}_{2} \text { Paramagnetic } \\
\text { instrument }\end{array}$ & $\begin{array}{l}16 \text { minute } \\
\text { integration time, } \\
2-3 \text { per meg dl }\end{array}$ & Jun 08-present & $\begin{array}{l}\text { Max-Planck-Institut für } \\
\text { Biogeochemie, Jena, } \\
\text { Germany }\end{array}$ \\
\hline $\mathrm{BrO} / \mathrm{IO} / \mathrm{NO}_{2} / \mathrm{O}_{4}$ & MAX-DOAS & $\begin{array}{l}\mathrm{IO}, 1.5 \text { pptv } \\
\mathrm{BrO}, 4.4 \mathrm{pptv} \\
\mathrm{NO} 2 \quad 150 \mathrm{pptv}\end{array}$ & $\begin{array}{l}\text { Nov } 06 \text { - Jan } 08, \\
\text { Sep } 08 \text { - May 09, } \\
\text { Nov } 09 \text { - present }\end{array}$ & $\begin{array}{l}\text { Institute of Environmental } \\
\text { University of Heidelberg, } \\
\text { Germany }\end{array}$ \\
\hline $\begin{array}{l}\mathrm{PM}_{10} \text { high volume } \\
720 \mathrm{~m}^{3} / \text { day }\end{array}$ & $\begin{array}{l}\text { DIGITEL DHA-80 } \\
\text { HV-sampler }\end{array}$ & $\begin{array}{l}24 \text { (48) hour } \\
\text { sampling interval }\end{array}$ & $\begin{array}{l}\text { May-Jun 07, } \\
\text { Dec 07, Jul 08, } \\
\text { Jan-Feb 09, } \\
\text { May-Jun 09, } \\
\text { Jan-Feb 10, } \\
\text { Jan-Feb 11 }\end{array}$ & $\begin{array}{l}\text { Leibniz-Institut für } \\
\text { Troposphärenforschung, } \\
\text { Germany }\end{array}$ \\
\hline $\begin{array}{l}\text { Size segregated } \\
\text { PM }(50 \mathrm{~nm}-40 \mathrm{~nm}- \\
420 \mathrm{~nm}-1.2 \mu \mathrm{m}- \\
3.5 \mu \mathrm{m}-10 \mu \mathrm{m})\end{array}$ & Berner Impactor & $\begin{array}{l}24(48) \text { hour } \\
\text { sampling interval }\end{array}$ & $\begin{array}{l}\text { May-Jun 07, } \\
\text { Dec 07, Jul 08, } \\
\text { Jan-Feb 09, } \\
\text { May-Jun 09, } \\
\text { Jan-Feb 10, } \\
\text { Jan-Feb 11 }\end{array}$ & $\begin{array}{l}\text { Leibniz-Institut für } \\
\text { Troposphärenforschung, } \\
\text { Germany }\end{array}$ \\
\hline $\begin{array}{l}\text { Hygrsocipicity } \\
\text { measurements }\end{array}$ & $\begin{array}{l}\text { Humidified DMA- } \\
\text { APS to distinguish } \\
\text { between seasalt and } \\
\text { mineral dust }\end{array}$ & $20 \mathrm{~min}$ & May 07 - present & $\begin{array}{l}\text { Leibniz-Institut für } \\
\text { Troposphärenforschung, } \\
\text { Germany }\end{array}$ \\
\hline Aerosol & SOAP & 1 hour & May 07 - present & Leibniz-Institut für \\
\hline
\end{tabular}




\begin{tabular}{|c|c|c|c|c|}
\hline $\begin{array}{l}\text { Absorption 300- } \\
800 \mathrm{~nm}\end{array}$ & & & & $\begin{array}{l}\text { Troposphärenforschung, } \\
\text { Germany }\end{array}$ \\
\hline \multicolumn{5}{|c|}{ Non-permanent measurements } \\
\hline $\mathrm{BrO} / \mathrm{IO} / \mathrm{I}_{2}, \mathrm{OIO}$ & LP-DOAS & $\begin{array}{l}20 \text { min } \\
\text { integration time, } \\
0.9,0.5,5,2 \\
\text { pptv dl }\end{array}$ & $\begin{array}{l}\text { Nov 06-Jun 07, } \\
\text { Feb-Nov } 09\end{array}$ & University of Leeds, UK \\
\hline $\begin{array}{l}\mathrm{BrO} / \mathrm{IO} / \mathrm{O}_{3} / \mathrm{NO}_{2} / \\
\mathrm{I}_{2} / \mathrm{OIO} / \mathrm{HONO} / \\
\mathrm{HCHO} / \mathrm{ClO} / \mathrm{NO}_{3} / \\
\text { Glyoxal }\end{array}$ & $\begin{array}{l}\text { LP-DOAS (up to } 4 \\
\text { light paths) }\end{array}$ & $\begin{array}{l}\text { single sample } \\
\text { time } 1 \mathrm{~min} \text {, full } \\
\text { run } 4 \text { light paths } \\
25 \mathrm{~min} ; \\
\mathrm{dl}: 0.8 / 0.6 / \\
1000 / 30 / 8 / 2 / \\
40 / 300 / 30 / 2 / \\
70 \text { pptv }\end{array}$ & $\begin{array}{l}\text { Jun } 10-\text { Oct } 10 \\
\text { (June and Oct } \\
\text { measurements on } 4 \\
\text { light paths) }\end{array}$ & $\begin{array}{l}\text { University of Heidelberg, } \\
\text { Germany }\end{array}$ \\
\hline $\mathrm{IO} / \mathrm{NO}_{2} /$ Glyoxal & CE-DOAS & $\begin{array}{l}\text { min, } \\
\mathrm{dl}: 0.8 / 2 / \\
120 \mathrm{pptv}\end{array}$ & Jun 10 & $\begin{array}{l}\text { University of Heidelberg, } \\
\text { Germany }\end{array}$ \\
\hline Cloud base & Ceilometer & $\begin{array}{l}\text { Up to } 25000 \mathrm{ft} \\
\text { Acquisition time } \\
\min 15 \mathrm{~s}, \max \\
120 \mathrm{~s}\end{array}$ & Aug $07-$ Jun 08 & $\begin{array}{l}\text { NCAS, University of } \\
\text { York, UK and } \\
\text { IFM-GEOMAR (Leibniz- } \\
\text { Institut für } \\
\text { Meereswissenschaften an } \\
\text { der Universitat Kiel) }\end{array}$ \\
\hline $\begin{array}{l}\text { Leachable metals, } \\
\mathrm{NO}_{3}, \mathrm{PO}_{4}, \mathrm{DON} \text {, } \\
\mathrm{DOC} \text {, total metal } \\
\text { and } \mathrm{P} \text { conc. }\end{array}$ & $\begin{array}{l}4 \text { x } 47 \mathrm{~mm} \text { filters, } \\
\text { ICP-MS, } \\
\text { high temperature } \\
\text { combustion TOC- } \\
\text { TDN ion } \\
\text { chromatography and } \\
\text { nutrient analysers }\end{array}$ & $\begin{array}{l}48 \text { - } 72 \text { hour } \\
\text { sampling }\end{array}$ & July 07-October 09 & $\begin{array}{l}\text { National Oceanography } \\
\text { Centre, Southampton, UK }\end{array}$ \\
\hline $\begin{array}{l}\text { Dornier Aircraft } \\
\text { measurements of } \\
\mathrm{O}_{3}, \mathrm{CO}, \text { VOCs, } \\
\text { aerosol }\end{array}$ & Various & $\begin{array}{l}10 \mathrm{~s} \text { integration } \\
\text { time; } 1 \mathrm{ppbv}, \\
2 \mathrm{ppbv}, 1 \mathrm{pptv}, \mathrm{dl} \\
\text { for } \mathrm{O}_{3}, \mathrm{CO}, \\
\text { VOCs } \\
\text { respectively }\end{array}$ & May 07, Sept 09 & $\begin{array}{l}\text { NCAS, University of } \\
\text { York, UK }\end{array}$ \\
\hline \multicolumn{5}{|c|}{ During RHaMBLe 4-week $\left(18^{\text {th }}\right.$ May-15 ${ }^{\text {th }}$ June 2007) Intensive Experiment } \\
\hline $\mathrm{OH}, \mathrm{HO}_{2}$ & FAGE-LIF & $\begin{array}{l}0.04(\mathrm{OH}), 0.05 \\
\left(\mathrm{HO}_{2}\right) \mathrm{pptv} \mathrm{dl} \\
\text { (1minute) }\end{array}$ & May-Jun 07 & University of Leeds, UK \\
\hline $\mathrm{Cl}_{2}, \mathrm{I}_{2}, \mathrm{Br}_{2}$ & Quadrupole GC-MS & $\begin{array}{l}\mathrm{hr} \text { integration } \\
\text { time, } 1.9,<0.2 \\
\text { and }<0.3 \mathrm{pptv} \mathrm{dl} \\
\text { for } \mathrm{Cl}_{2}, \mathrm{I}_{2} \text { and } \\
\mathrm{Br}_{2} \text { respectively }\end{array}$ & May-Jun 07 & $\begin{array}{l}\text { University of California, } \\
\text { Irvine, USA }\end{array}$ \\
\hline $\begin{array}{l}\mathrm{HCl}, \mathrm{Cl}^{*} \\
\left(\mathrm{HOCl}+\mathrm{Cl}_{2}\right), \\
\mathrm{HNO}_{3}, \mathrm{HCOOH}, \\
\mathrm{CH}_{3} \mathrm{COOH}, \\
\mathrm{HONO} \\
\end{array}$ & $\begin{array}{l}\text { Tandem mist } \\
\text { chambers/Ion } \\
\text { chromatographs }\end{array}$ & $\begin{array}{l}2 \mathrm{hr} \text { integration } \\
\text { time, } 26,14,12 \text {, } \\
29,44 \text { pptv dl for } \\
\mathrm{HCl}, \mathrm{Cl}^{*}, \mathrm{HNO}_{3} \text {, } \\
\mathrm{HCOOH},\end{array}$ & May-Jun 07 & $\begin{array}{l}\text { University of Virginia and } \\
\text { University of New } \\
\text { Hampshire, USA }\end{array}$ \\
\hline
\end{tabular}




\begin{tabular}{|c|c|c|c|c|}
\hline & & $\begin{array}{l}\mathrm{CH}_{3} \mathrm{COOH} \\
\text { respectively }\end{array}$ & & \\
\hline $\begin{array}{l}\text { Total volatile } \\
\text { inorganic } \mathrm{Br} \text { and I }\end{array}$ & $\begin{array}{l}\text { Filter pack, neutron } \\
\text { activation analysis }\end{array}$ & $\begin{array}{l}4.9 \text { and } 2.7 \mathrm{ng} \\
\mathrm{m}^{-3}\end{array}$ & May-Jun 07 & $\begin{array}{l}\text { University of Virginia and } \\
\text { University of New } \\
\text { Hampshire, USA }\end{array}$ \\
\hline Halocarbons & GC- ECD & $<1 \mathrm{pptv} d \mathrm{l}$ & Jun 07-Jul 07 & $\begin{array}{l}\text { University of Cambridge, } \\
\text { UK }\end{array}$ \\
\hline \multicolumn{5}{|c|}{ During Seasonal Oxidant Study 4 x 3 week campaigns 2009} \\
\hline $\mathrm{OH}, \mathrm{HO}_{2}$ & FAGE-LIF & $\begin{array}{l}0.04(\mathrm{OH}), 0.05 \\
\left(\mathrm{HO}_{2}\right) \mathrm{pptv} \mathrm{dl} \\
(1 \text { minute })\end{array}$ & $\begin{array}{l}\text { Feb, May, Sept, } \\
\text { Nov } 09\end{array}$ & University of Leeds, UK \\
\hline $\mathrm{HO}_{2}, \mathrm{RO}_{2}$ & PERCA & $\begin{array}{l}10 \quad \text { minute } \\
\text { integration time, } \\
0.04 \text { pptv dl and } \\
38 \% \text { error }\end{array}$ & $\begin{array}{l}\text { Feb, May, Sept, } \\
\text { Nov } 09\end{array}$ & $\begin{array}{l}\text { University of Leicester, } \\
\text { UK }\end{array}$ \\
\hline Photolysis rates & Radiometers & $\begin{array}{l}1 \text { min integration } \\
\text { time }\end{array}$ & Feb-Nov 09 & $\begin{array}{l}\text { University of Leicester, } \\
\text { UK }\end{array}$ \\
\hline $\begin{array}{l}\text { Dihalogens, } \\
\mathrm{HOCl} / \mathrm{HOBr}\end{array}$ & $\begin{array}{l}\text { Quadrapole Mass } \\
\text { Spectrometry }\end{array}$ & $\begin{array}{l}1 \text { hour } \\
\text { integration time, } \\
1.9,<0.2 \text { and }< \\
0.3 \text { pptv dl for } \\
\mathrm{Cl}_{2}, \mathrm{I}_{2} \text { and } \mathrm{Br}_{2} \\
\text { respectively }\end{array}$ & May-Jun 09 & $\begin{array}{l}\text { University of California, } \\
\text { Irvine, USA }\end{array}$ \\
\hline
\end{tabular}

Table 2. Classification of aerosol mass concentration collected on HV-filters during January 2007- February 2010

\begin{tabular}{llllll}
\hline $\begin{array}{l}\text { Mass } \\
\begin{array}{l}\text { concentration } \\
\text { classes }\left[\mu \mathrm{g} / \mathrm{m}^{3}\right]\end{array}\end{array}$ & Total & $\begin{array}{l}\text { Winter } \\
\text { Dec. }- \text { Feb. }\end{array}$ & $\begin{array}{l}\text { Spring } \\
\text { Mar. - May }\end{array}$ & $\begin{array}{l}\text { Summer } \\
\text { Jun. - Aug. }\end{array}$ & $\begin{array}{l}\text { Autumn } \\
\text { Sep. - Nov. }\end{array}$ \\
\hline $\begin{array}{l}\text { samples } \\
>200\end{array}$ & 410 & 177 & 86 & 77 & 70 \\
$90-200$ & 17 & 14 & 1 & 0 & 2 \\
$60-90$ & 60 & 40 & 5 & 1 & 14 \\
$25-60$ & 43 & 31 & 3 & 3 & 6 \\
$<25$ & 167 & 53 & 39 & 41 & 34 \\
\hline
\end{tabular}


Table 3. Mean, median (in brackets) and standard deviation mixing ratios of summer Atlantic (June, July, August) 2007-2009 and winter dust period (December, January, February) 2006-2009 chemical species and meteorological parameters from each air mass sector type.

*Values for air mass sectors with fewer than five measurements in the whole season are not shown - the North American and Atlantic air sector do not occur often in summer

** $\mathrm{NO}, \mathrm{NO}_{2}$ and $\mathrm{NO}_{\mathrm{y}}$ have had an extra filter used to exclude all possible local contamination (excluding all local winds from south and west $\left(100^{\circ}\right.$ to $\left.360^{\circ}\right)$

***Aerosol measurements used for averages are only from January 2008 to October 2009

\begin{tabular}{|c|c|c|c|c|c|c|c|}
\hline $\begin{array}{l}\text { SUMMER } \\
\text { (JJA) }\end{array}$ & $\begin{array}{l}\text { Atlantic and } \\
\text { coastal } \\
\text { AAC }\end{array}$ & $\begin{array}{l}\text { Atlantic } \\
\text { marine only } \\
\text { AM }\end{array}$ & $\begin{array}{l}\text { North } \\
\text { American } \\
+ \text { Atlantic } \\
\text { NAA }\end{array}$ & $\begin{array}{l}\text { North } \\
\text { American + } \\
\text { African coast } \\
\text { NCA }\end{array}$ & $\begin{array}{l}\text { European } \\
\text { (and coastal } \\
\text { Africa) } \\
\text { EUR }\end{array}$ & $\begin{array}{l}\text { Africa (no } \\
\text { European) } \\
\text { AFR }\end{array}$ & $\begin{array}{l}\text { Africa and } \\
\text { Europe } \\
\text { EUR/AFR }\end{array}$ \\
\hline $\mathrm{CO}, \mathrm{ppbv}$ & $\begin{array}{l}85.2 \\
\pm 11.7 .2\end{array}$ & (80.9) & $-*$ & $\begin{array}{l}90.8 \quad \text { (94.8) } \\
\pm 11.4\end{array}$ & $\begin{array}{l}88.8 \\
\pm 11.5\end{array}$ & $\begin{array}{l}81.3(\mathbf{7 9 . 6}) \\
\pm 7.5\end{array}$ & $\begin{array}{ll}89.3 & \text { (82.6) } \\
\pm 12.7 & \end{array}$ \\
\hline $\mathrm{O}_{3}, \mathrm{ppbv}$ & $\begin{array}{l}23.8 \\
\pm 8.4\end{array}$ & (23.7) & - & (29.1) & (24.8) & $\begin{array}{l}19.2 \quad \text { (19.6) } \\
\pm 5.5\end{array}$ & (24.5) \\
\hline NO**, pptv & $\begin{array}{l}3.1 \\
\pm 4.6\end{array}$ & $\begin{array}{l}2.3 \\
\pm 3.6\end{array}$ & - & (1.6) & (1.6) & (1.9) & (1.3) \\
\hline $\begin{array}{l}\text { Midday NO, pptv } \\
(9.00-15.00)\end{array}$ & $\begin{array}{l}4.2 \\
\pm 3.6\end{array}$ & $\begin{array}{l}3.1 \\
\pm 3.4\end{array}$ & - & (3.1) & (2.9) & - & - \\
\hline $\mathrm{NO}_{2}, \mathrm{pptv}$ & $\begin{array}{l}19.1 \\
\pm 12.8\end{array}$ & (10.6) & - & (12.2) & $\begin{array}{l}23.1 \\
\pm 15.6\end{array}$ & $\begin{array}{l}30.2 \\
\pm 22.4\end{array}$ & $\begin{array}{ll}18.1 & (\mathbf{1 4 . 8}) \\
\pm 14.4 & \end{array}$ \\
\hline $\mathrm{NO}_{\mathrm{y}}, \mathrm{pptv}$ & $\begin{array}{l}349.6 \\
\pm 117.5\end{array}$ & (214.8) & - & (319.0) & $\begin{array}{l}504.2 \quad \text { (480.5) } \\
\pm 167.7\end{array}$ & $\begin{array}{l}607.2 \quad \text { (691.7) } \\
\pm 236.5\end{array}$ & $\begin{array}{ll}621.4 & \text { (628.6) } \\
\pm 190.2 & \end{array}$ \\
\hline ethane, pptv & $\begin{array}{l}458.6 \\
\pm 137.5\end{array}$ & $\begin{array}{l}515.9 \quad(\mathbf{5 2 6 . 5}) \\
\pm 107.0\end{array}$ & - & $(522.0)$ & $\begin{array}{l}400.6 \quad(355.1) \\
\pm 140.5\end{array}$ & (366.5) & $\begin{array}{ll}255.2 & (\mathbf{2 5 8 . 7}) \\
\pm 54.6 & \end{array}$ \\
\hline propane, pptv & $\begin{array}{l}30.2 \\
\pm 55.3\end{array}$ & $\begin{array}{l}25.5 \\
\pm 13.1\end{array}$ & - & (29.0) & $\begin{array}{l}22.3 \\
\pm 12.6\end{array}$ & $\begin{array}{l}28.6 \\
\pm 27.5\end{array}$ & (21.3) \\
\hline isobutane, pptv & $\begin{array}{l}2.7 \\
\pm 2.7\end{array}$ & $\begin{array}{l}1.2 \\
\pm 1.3\end{array}$ & - & (2.7) & (4.0) & (5.2) & (5.0) \\
\hline n-butane, pptv & $\begin{array}{l}4.3 \\
\pm 6.7\end{array}$ & $\begin{array}{l}2.6 \\
\pm 25.8\end{array}$ & - & (3.9) & (3.9) & (4.6) & (4.4) \\
\hline acetylene, pptv & $\begin{array}{l}57.7 \\
\pm 31.7\end{array}$ & $\begin{array}{l}52.8 \\
\pm 25.8\end{array}$ & - & $\begin{array}{l}44.0 \\
\pm 11.7\end{array}$ & $\begin{array}{l}54.4 \\
\pm 21.8\end{array}$ & $\begin{array}{l}103.0 \\
\pm 48.7\end{array}$ & (66.8) \\
\hline ethene, pptv & $\begin{array}{l}26.8 \\
\pm 38.7\end{array}$ & $\begin{array}{l}16.2 \\
\pm 10.8\end{array}$ & - & $\begin{array}{l}24.4 \\
\pm 21.3\end{array}$ & $\begin{array}{l}26.2 \\
\pm 16.1\end{array}$ & $\begin{array}{l}41.4 \\
\pm 27.2\end{array}$ & (17.0) \\
\hline propene, pptv & $\begin{array}{l}17.8 \\
\pm 12.4\end{array}$ & $\begin{array}{l}17.3 \\
\pm 6.5\end{array}$ & - & $\begin{array}{l}21.1 \\
\pm 12.7\end{array}$ & $\begin{array}{l}21.4 \\
\pm 10.6\end{array}$ & $\begin{array}{l}24.3 \\
\pm 7.9\end{array}$ & (18.0) \\
\hline methanol, pptv & $\begin{array}{r}1067.2 \\
\pm 520.3\end{array}$ & $\begin{array}{l}1046.8 \quad(\mathbf{1 1 5 9 . 7}) \\
\pm 434.2\end{array}$ & - & $\begin{array}{ll}1305.4 & (\mathbf{1 3 5 1 . 0}) \\
\pm 425.3 & \end{array}$ & $\begin{array}{ll}1032.5 & (\mathbf{1 0 5 2 . 9}) \\
\pm 498.7 & \end{array}$ & $\begin{array}{l}954.6 \quad \text { (799.5) } \\
\pm 826.0\end{array}$ & $\begin{array}{ll}1626.5 & (\mathbf{1 5 9 5 . 1}) \\
\pm 128.5 & \end{array}$ \\
\hline acetone, pptv & $\begin{array}{l}805.2 \\
\pm 279.9\end{array}$ & $\begin{array}{l}555.0 \quad \text { (486.9) } \\
\pm 221.3\end{array}$ & - & $\begin{array}{l}697.9 \quad(\mathbf{5 6 5 . 8}) \\
\pm 312.9\end{array}$ & $\begin{array}{l}887.8 \quad(845.5) \\
\pm 327.3\end{array}$ & $\begin{array}{l}791.6 \quad(\mathbf{8 3 7 . 8}) \\
\pm 227.3\end{array}$ & $\begin{array}{ll}1571.1 \quad(\mathbf{1 5 1 7 . 1}) \\
\pm 452.1\end{array}$ \\
\hline
\end{tabular}




\begin{tabular}{|c|c|c|c|c|c|c|c|c|c|c|c|c|c|}
\hline $\begin{array}{l}\text { Aerosol number***, } \\
1 / \mathrm{cm}^{3}\end{array}$ & $\begin{array}{l}516.2 \\
\pm 166.2\end{array}$ & (523.6) & $\begin{array}{l}521.1 \\
\pm 158.3\end{array}$ & (521.0) & - & $\begin{array}{l}491.1 \\
\pm 163.1\end{array}$ & (472.9) & $\begin{array}{l}468.8 \\
\pm 134.3\end{array}$ & (457.9) & $\begin{array}{l}567.3 \\
\pm 119.9\end{array}$ & $(582.0)$ & & \\
\hline $\begin{array}{l}\text { Aerosol surface } \\
\text { area, } \mu \mathrm{m}^{2} / \mathrm{cm}^{3}\end{array}$ & $\begin{array}{l}82.5 \\
\pm 42.3\end{array}$ & (75.7) & $\begin{array}{l}62.5 \\
\pm 26.0\end{array}$ & (60.0) & - & $\begin{array}{l}92.3 \\
\pm 43.0\end{array}$ & (104.6) & $\begin{array}{l}84.1 \\
\pm 39.1\end{array}$ & $(82.6)$ & $\begin{array}{l}84.3 \\
\pm 35.1\end{array}$ & (87.1) & & \\
\hline $\begin{array}{l}\text { Aerosol volume, } \\
\mu \mathrm{m}^{3} / \mathrm{cm}^{3}\end{array}$ & $\begin{array}{l}13.9 \\
\pm 9.3\end{array}$ & (10.4) & $\begin{array}{l}7.7 \\
\pm 3.7\end{array}$ & (5.8) & - & $\begin{array}{l}16.9 \\
\pm 10.2\end{array}$ & (19.3) & $\begin{array}{l}15.0 \\
\pm 8.7\end{array}$ & $(16.8)$ & $\begin{array}{l}11.7 \\
\pm 8.0\end{array}$ & (11.1) & & \\
\hline Wind speed, $\mathrm{m} / \mathrm{s}$ & $\begin{array}{l}6.1 \\
\pm 2.0\end{array}$ & (6.4) & $\begin{array}{l}6.5 \\
\pm 1.8\end{array}$ & (6.6) & - & $\begin{array}{l}6.8 \\
\pm 1.9\end{array}$ & (6.9) & $\begin{array}{l}6.1 \\
\pm 2.1\end{array}$ & (6.4) & $\begin{array}{l}3.9 \\
\pm 1.5\end{array}$ & (3.7) & $\begin{array}{l}4.9 \\
\pm 2.3\end{array}$ & (4.4) \\
\hline Temperature, ${ }^{\circ} \mathrm{C}$ & $\begin{array}{l}24.6 \\
\pm 1.2\end{array}$ & (24.6) & $\begin{array}{l}23.6 \\
\pm 0.7\end{array}$ & (23.5) & - & $\begin{array}{l}24.2 \\
\pm 1.1\end{array}$ & (23.8) & $\begin{array}{l}25.0 \\
\pm 1.2\end{array}$ & $(\mathbf{2 4 . 8 )}$ & $\begin{array}{l}25.7 \\
\pm 1.1\end{array}$ & (25.4) & $\begin{array}{l}25.4 \\
\pm 0.9\end{array}$ & (25.5) \\
\hline $\begin{array}{l}\text { Relative Humidity, } \\
\%\end{array}$ & $\begin{array}{l}82.7 \\
\pm 4.2\end{array}$ & (83.0) & $\begin{array}{l}79.1 \\
\pm 3.5\end{array}$ & (79.4) & - & $\begin{array}{l}81.1 \\
\pm 3.6\end{array}$ & $(81.2)$ & $\begin{array}{l}83.8 \\
\pm 3.5\end{array}$ & (83.9) & $\begin{array}{l}89.5 \\
\pm 1.5\end{array}$ & (89.5) & $\begin{array}{l}86.3 \\
\pm 3.3\end{array}$ & (86.5) \\
\hline $\begin{array}{l}\text { Solar Radiation, } \\
\mathrm{W} / \mathrm{m}^{2}\end{array}$ & $\begin{array}{l}216.0 \\
\pm 268.5\end{array}$ & (59.3) & $\begin{array}{l}237.5 \\
\pm 283.3\end{array}$ & $(68.7)$ & - & $\begin{array}{l}262.2 \\
\pm 287.4\end{array}$ & (84.1) & $\begin{array}{l}214.5 \\
\pm 265.3\end{array}$ & $(54.7)$ & $\begin{array}{l}96.8 \\
\pm 200.8\end{array}$ & $(2.0)$ & $\begin{array}{l}147.2 \\
\pm 226.4\end{array}$ & (18.2) \\
\hline
\end{tabular}

\begin{tabular}{|c|c|c|c|c|c|c|c|}
\hline WINTER & $\begin{array}{l}\text { Atlantic and } \\
\text { coastal } \\
\text { AAC }\end{array}$ & $\begin{array}{l}\text { Atlantic } \\
\text { marine only } \\
\text { AM }\end{array}$ & $\begin{array}{l}\text { North } \\
\text { American + } \\
\text { Atlantic NAA }\end{array}$ & $\begin{array}{l}\text { North } \\
\text { American + } \\
\text { African coast } \\
\text { NCA }\end{array}$ & $\begin{array}{l}\text { European } \\
\text { (and coastal } \\
\text { Africa) } \\
\text { EUR }\end{array}$ & $\begin{array}{l}\text { Africa (no } \\
\text { European) } \\
\text { AFR }\end{array}$ & $\begin{array}{l}\text { Africa and } \\
\text { Europe } \\
\text { EUR/AFR }\end{array}$ \\
\hline $\mathrm{CO}, \mathrm{ppbv}$ & $\begin{array}{ll}106.5 & (\mathbf{1 0 4 . 8}) \\
\pm 8.2\end{array}$ & $\begin{array}{ll}109.0 & (\mathbf{1 1 2 . 7}) \\
\pm 7.6 & \end{array}$ & $\begin{array}{l}116.8 \quad \text { (116.2) } \\
\pm 13.1\end{array}$ & $\begin{array}{l}116.0 \quad(113.2) \\
\pm 8.9\end{array}$ & $\begin{array}{l}113.2 \quad(\mathbf{1 1 3 . 4}) \\
\pm 9.4\end{array}$ & $\begin{array}{ll}104.6 & (104.6) \\
\pm 10.5\end{array}$ & $\begin{array}{ll}110.0 & (\mathbf{1 0 9 . 4}) \\
\pm 9.8 & \end{array}$ \\
\hline $\mathrm{O}_{3}, \mathrm{ppbv}$ & (37.0) & $\begin{array}{ll}32.8 & (\mathbf{3 2 . 0}) \\
\pm 5.7 & \end{array}$ & (37.2) & (40.0) & (39.7) & (34.7) & (36.9) \\
\hline NO**, pptv & $\begin{array}{l}2.9 \\
\pm 3.8\end{array}$ & $\begin{array}{ll}8.4 & \text { (4.0) } \\
\pm 12.5 & \end{array}$ & (1.8) & (1.9) & (1.4) & $\begin{array}{l}3.1 \\
\pm 4.3\end{array}$ & $\begin{array}{l}4.0 \\
\pm 5.6\end{array}$ \\
\hline $\begin{array}{l}\text { Midday NO, pptv } \\
(9.00-15.00)\end{array}$ & $\begin{array}{l}4.5 \\
\pm 4.3\end{array}$ & $-*$ & $\begin{array}{l}5.0 \\
\pm 4.4\end{array}$ & $\begin{array}{l}4.0 \\
\pm 3.2\end{array}$ & $\begin{array}{l}6.0 \\
\pm 6.0\end{array}$ & $\begin{array}{l}6.8 \\
\pm 5.8\end{array}$ & $\begin{array}{l}9.6 \\
\pm 9.8\end{array}$ \\
\hline $\mathrm{NO}_{2}, \mathrm{pptv}$ & $\begin{array}{l}24.0 \\
\pm 14.8\end{array}$ & - & $\begin{array}{l}28.1 \\
\pm 22.8\end{array}$ & $\begin{array}{l}29.3 \\
\pm 16.9\end{array}$ & $\begin{array}{l}28.1 \\
\pm 13.8\end{array}$ & $\begin{array}{l}33.0 \\
\pm 17.8\end{array}$ & $\begin{array}{l}43.0 \\
\pm 22.3\end{array}$ \\
\hline NOy, pptv & $\begin{array}{l}389.1 \\
\pm 158.3\end{array}$ & $\begin{array}{ll}342.8 & (333.0) \\
\pm 101.5 & \end{array}$ & $\begin{array}{ll}228.9 & (\mathbf{2 0 0 . 3}) \\
\pm 122.1 & \end{array}$ & $\begin{array}{ll}335.9 & \text { (326.4) } \\
\pm 118.0 & \end{array}$ & $\begin{array}{ll}453.7 & \text { (434.9) } \\
\pm 145.8\end{array}$ & $\begin{array}{ll}542.7 & \text { (493.6) } \\
\pm 230.4\end{array}$ & $\begin{array}{ll}507.5 & (\mathbf{4 7 9 . 8}) \\
\pm 170.0 & \end{array}$ \\
\hline ethane, pptv & $\begin{array}{ll}1069.5 & (\mathbf{1 0 4 4 . 4}) \\
\pm 230.6 & \end{array}$ & - & $\begin{array}{ll}1298.8 \quad(\mathbf{1 2 8 2 . 5}) \\
\pm 281.1\end{array}$ & $\begin{array}{ll}1288.2 & (\mathbf{1 3 3 9 . 5}) \\
\pm 230.9 & \end{array}$ & $\begin{array}{ll}1183.3 \quad(1155.0) \\
\pm 200.2\end{array}$ & $\begin{array}{ll}1155.6 \quad(1145.0) \\
\pm 190.6\end{array}$ & $\begin{array}{ll}1052.7 & \text { (1019.4) } \\
\pm 163.4 & \end{array}$ \\
\hline propane, pptv & $\begin{array}{l}227.5 \quad \text { (190.1) } \\
\pm 126.9\end{array}$ & - & $\begin{array}{l}345.0 \\
\pm 161.5\end{array}$ & $\begin{array}{ll}328.5 & \text { (292.0) } \\
\pm 137.2\end{array}$ & $\begin{array}{ll}289.1 & \text { (270.9) } \\
\pm 115.7\end{array}$ & $\begin{array}{l}284.0 \quad \text { (282.3) } \\
\pm 125.7\end{array}$ & $\begin{array}{ll}275.1 & \text { (298.1) } \\
\pm 89.9 & \end{array}$ \\
\hline isobutane, pptv & $\begin{array}{l}25.5 \\
\pm 21.2\end{array}$ & - & $\begin{array}{l}37.3 \\
\pm 25.4\end{array}$ & $\begin{array}{l}43.4 \\
\pm 19.9\end{array}$ & $\begin{array}{l}35.9 \\
\pm 22.0\end{array}$ & $\begin{array}{l}40.6 \\
\pm 21.7\end{array}$ & $\begin{array}{l}42.0 \\
\pm 18.9\end{array}$ \\
\hline n-butane, pptv & $\begin{array}{l}37.0 \\
\pm 36.7\end{array}$ & - & $\begin{array}{l}61.5 \\
\pm 47.0\end{array}$ & (76.2) & $\begin{array}{l}53.4 \\
\pm 37.9\end{array}$ & $\begin{array}{l}63.9 \\
\pm 36.2\end{array}$ & $\begin{array}{l}64.6 \\
\pm 30.9\end{array}$ \\
\hline
\end{tabular}




\begin{tabular}{|c|c|c|c|c|c|c|c|c|c|c|c|c|c|}
\hline acetylene, pptv & $\begin{array}{l}157.3 \\
\pm 47.5\end{array}$ & $(152.0)$ & - & $\begin{array}{l}174.6 \\
\pm 49.6\end{array}$ & (186.2) & $\begin{array}{l}173.6 \\
\pm 60.0\end{array}$ & (186.5) & $\begin{array}{l}163.1 \\
\pm 53.1\end{array}$ & (156.7) & $\begin{array}{l}171.9 \\
\pm 57.9\end{array}$ & (171.5) & $\begin{array}{l}156.1 \\
\pm 77.9\end{array}$ & (113.1) \\
\hline ethene, pptv & $\begin{array}{l}10.9 \\
\pm 8.1\end{array}$ & (14.2) & - & $\begin{array}{l}34.0 \\
\pm 24.6\end{array}$ & (32.5) & $\begin{array}{l}15.5 \\
\pm 11.4\end{array}$ & (16.6) & $\begin{array}{l}17.3 \\
\pm 26.1\end{array}$ & (3.4) & $\begin{array}{l}18.7 \\
\pm 10.9\end{array}$ & (18.9) & $\begin{array}{l}16.2 \\
\pm 16.7\end{array}$ & (5.4) \\
\hline propene, pptv & $\begin{array}{r}12.7 \\
\pm 6.5\end{array}$ & $(\mathbf{1 5 . 8})$ & - & $\begin{array}{r}12.0 \\
\pm 6.5\end{array}$ & (10.4) & $9.5(7.8)$ & \pm 6.6 & $\begin{array}{r}17.4 \\
\pm 5.5\end{array}$ & $(18.1)$ & $9.7(\mathbf{8 . 2})$ & \pm 6.1 & $\begin{array}{r}12.0 \\
\pm 5.4\end{array}$ & (11.1) \\
\hline methanol, pptv & $\begin{array}{l}553.8 \\
\pm 261.2\end{array}$ & $(622.5)$ & - & $\begin{array}{l}764.5 \\
\pm 202.5\end{array}$ & $(741.9)$ & $\begin{array}{l}697.4 \\
\pm 251.9\end{array}$ & $(705.8)$ & $\begin{array}{l}534.6 \\
\pm 280.9\end{array}$ & $(633.0)$ & $\begin{array}{l}728.6 \\
\pm 466.2\end{array}$ & (679.1) & $\begin{array}{l}885.4 \\
\pm 217.1\end{array}$ & (787.6) \\
\hline acetone, pptv & $\begin{array}{l}695.7 \\
\pm 223.0\end{array}$ & $(694.1)$ & - & $\begin{array}{l}777.1 \\
\pm 380.6\end{array}$ & $(765.1)$ & $\begin{array}{l}634.1 \\
\pm 269.9\end{array}$ & $(632.0)$ & $\begin{array}{l}720.7 \\
\pm 392.4\end{array}$ & $(635.4)$ & $\begin{array}{l}694.7 \\
\pm 438.5\end{array}$ & $(622.5)$ & $\begin{array}{l}803.3 \\
\pm 642.5\end{array}$ & $(563.2)$ \\
\hline $\begin{array}{l}\text { Aerosol number***, } \\
1 / \mathrm{cm}^{3}\end{array}$ & $\begin{array}{l}534.4 \\
\pm 101.5\end{array}$ & $(554.8)$ & $\begin{array}{l}382.5 \quad \text { (364.6) } \\
\pm 65.7\end{array}$ & $\begin{array}{l}631.0 \\
\pm 212.7\end{array}$ & $(613.7)$ & $\begin{array}{l}559.7 \\
\pm 189.5\end{array}$ & $(548.2)$ & $\begin{array}{l}484.4 \\
\pm 144.4\end{array}$ & $(510.6)$ & $\begin{array}{l}586.9 \\
\pm 205.1\end{array}$ & $(532.3)$ & $\begin{array}{l}562.3 \\
\pm 112.1\end{array}$ & $(562.5)$ \\
\hline $\begin{array}{l}\text { Aerosol surface, } \\
\mu \mathrm{m}^{2} / \mathrm{cm}^{3}\end{array}$ & $\begin{array}{r}105.4 \\
\pm 20.4\end{array}$ & $(100.2)$ & $\begin{array}{l}63.1 \\
\pm 24.3\end{array}$ & $\begin{array}{l}111.2 \\
\pm 34.5\end{array}$ & (116.4) & $\begin{array}{l}91.6 \\
\pm 28.6\end{array}$ & (88.1) & $\begin{array}{l}87.0 \\
\pm 35.5\end{array}$ & $(85.0)$ & $\begin{array}{r}104.0 \\
\pm 36.8\end{array}$ & $(104.5)$ & $\begin{array}{l}99.0 \\
\pm 28.3\end{array}$ & (104.9) \\
\hline $\begin{array}{l}\text { Aerosol volume, } \\
\mu \mathrm{m}^{3} / \mathrm{cm}^{3}\end{array}$ & $\begin{array}{r}17.6 \\
\pm 3.6\end{array}$ & (18.5) & (12.9) & $\begin{array}{r}20.9 \\
\pm 8.1\end{array}$ & (21.5) & $\begin{array}{r}14.6 \\
\pm 5.5\end{array}$ & (14.4) & $\begin{array}{r}15.8 \\
\pm 8.5\end{array}$ & (14.6) & $\begin{array}{r}16.6 \\
\pm 9.1\end{array}$ & (14.7) & $\begin{array}{r}16.8 \\
\pm 5.7\end{array}$ & (16.3) \\
\hline Wind speed, $\mathrm{m} / \mathrm{s}$ & $\begin{array}{l}7.3 \\
\pm 2.8\end{array}$ & $(\mathbf{8 . 5})$ & $\begin{array}{l}6.4 \\
\pm 1.6\end{array}$ & $\begin{array}{l}7.2 \\
\pm 2.4\end{array}$ & $(7.5)$ & $\begin{array}{l}8.6 \\
\pm 2.2\end{array}$ & $(8.9)$ & $\begin{array}{l}8.2 \\
\pm 2.3\end{array}$ & $(\mathbf{8 . 5})$ & $\begin{array}{l}6.5 \\
\pm 2.2\end{array}$ & $(6.6)$ & $\begin{array}{l}6.4 \\
\pm 2.5\end{array}$ & (6.1) \\
\hline Temperature, ${ }^{\circ} \mathrm{C}$ & $\begin{array}{r}21.5 \\
\pm 0.7\end{array}$ & $(21.5)$ & $\begin{array}{l}22.6 \\
\pm 1.3\end{array}$ & $\begin{array}{r}21.5 \\
\pm 0.7\end{array}$ & (21.4) & $\begin{array}{r}21.6 \\
\pm 0.8\end{array}$ & (21.6) & $\begin{array}{l}21.6 \\
\pm 0.9\end{array}$ & (21.6) & $\begin{array}{l}22.5 \\
\pm 1.1\end{array}$ & $(22.4)$ & $\begin{array}{r}22.7 \\
\pm 1.2\end{array}$ & (23.0) \\
\hline $\begin{array}{l}\text { Relative Humidity, } \\
\%\end{array}$ & $\begin{array}{r}77.1 \\
\pm 4.5\end{array}$ & (77.4) & $\begin{array}{r}76.7 \\
\pm 8.8\end{array}$ & $\begin{array}{r}76.3 \\
\pm 5.2\end{array}$ & $(76.3)$ & $\begin{array}{r}74.4 \\
\pm 5.3\end{array}$ & (72.7) & $\begin{array}{r}74.2 \\
\pm 5.2\end{array}$ & (73.4) & $\begin{array}{r}75.7 \\
\pm 6.0\end{array}$ & $(76.0)$ & $\begin{array}{r}73.7 \\
\pm 5.6\end{array}$ & (73.2) \\
\hline $\begin{array}{l}\text { Solar Radiation, } \\
\mathrm{W} / \mathrm{m}^{2}\end{array}$ & $\begin{array}{l}153.8 \\
\pm 209.5\end{array}$ & (13.3) & $\begin{array}{l}302.1 \quad(\mathbf{2 6 2 . 7}) \\
\pm 306.1\end{array}$ & $\begin{array}{l}138.7 \\
\pm 195.7\end{array}$ & (13.1) & $\begin{array}{l}144.9 \\
\pm 192.2\end{array}$ & $(16.5)$ & $\begin{array}{l}160.8 \\
\pm 209.7\end{array}$ & (22.2) & $\begin{array}{l}150.7 \\
\pm 205.9\end{array}$ & (14.9) & $\begin{array}{l}152.7 \\
\pm 201.5\end{array}$ & (17.7) \\
\hline
\end{tabular}

